\section{NOVA TELLVS}

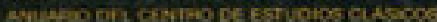

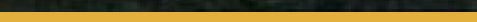

Nova Tellus

ISSN: 0185-3058

novatelu@servidor.unam.mx

Centro de Estudios Clásicos

México

ZUMAYA ROMÁN, Myriam

Duris de Samos, Testimonios y fragmentos

Nova Tellus, vol. 24, núm. 1, 2006, pp. 181-251

Centro de Estudios Clásicos

Distrito Federal, México

Disponible en: http://www.redalyc.org/articulo.oa?id=59114742009

- Cómo citar el artículo

- Número completo

- Más información del artículo

- Página de la revista en redalyc.org

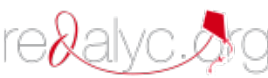

Sistema de Información Científica

Red de Revistas Científicas de América Latina, el Caribe, España y Portugal

Proyecto académico sin fines de lucro, desarrollado bajo la iniciativa de acceso abierto 


\title{
Duris de Samos, Testimonios y fragmentos
}

\author{
Myriam ZumaYa Román \\ Universidad Nacional Autónoma de México
}

myriamzumaya@yahoo.com.mx

RESUMEN: En este artículo se presentan los testimonios y los fragmentos que se conservan del historiador helenista Duris de Samos, autor prácticamente inédito en lenguas modernas, acompañado de un estudio introductorio y su traducción al español.

$$
* * *
$$

ABSTRACT: This article presents the testimonia and the fragments of the Hellenistic historian Duris of Samos, an author practically unpublished in any modern language, along with an introduction and a Spanish translation.

Palabras Clave: Duris de Samos, fragmentos, historia, historiografía trágica, testimonios.

RECEPCIÓN: 7 de febrero de 2006.

ACEPTACIÓN: 29 de marzo de 2006. 



\title{
Duris de Samos, Testimonios y fragmentos
}

\author{
Myriam ZumaYa RoMÁn
}

Historiam puto scribendam esse et cum ira et cum studio

Bardt

Una breve mirada a la historiografía griega

de la época helenística

Uno de los más complejos y fascinantes momentos de la historia griega ocurrió durante el helenismo. La transformación histórica se inició en el siglo III $^{1}$ con Filipo de Macedonia, quien incluso tenía un historiógrafo de cabecera, Teopompo, el primero de una nueva generación de historiadores: los sucesos que habrían de ocurrir en los siguientes años necesitaban quedar asentados por escrito - y por muchas plumas-.$^{2}$ Teopompo marcó una ruptura con la antigua tradición de escribir historia, sus personajes ya no fueron solamente jefes de estado o grandes dirigentes, cuyo único interés histórico para el lector moderno fuera su papel político; sino también fueron individuos de carne y hueso atormentados por vicios, excesos y pasiones, personas reales cuya existencia nos revela un cam-

\footnotetext{
${ }^{1}$ Todas las fechas, a menos que se indique lo contrario, son antes de Cristo.

${ }^{2}$ Estos historiógrafos "modernos" son: Éforo, que escribió 29 libros y dejó su obra inconclusa; Duris, con 24 libros de Historias macedonias, entre otros; Filarco, con 28 libros de Historias; Timeo, con al menos 38 libros de Historia de Sicilia, y más tarde Posidonio, con una obra histórica de 52 libros, y Polibio, con 50. El mismo Teopompo fue un historiador prolífico con 12 libros de Helénicas y 58 de Filípicas.
} 
bio de mentalidad decisivo: ${ }^{3}$ El ser humano se convirtió en lo más importante para el desarrollo de la historia.

La visión de Teopompo llegó muy lejos. Él descubrió que el destino de Grecia dependía de la voluntad de un solo hombre, más que de las rivalidades entre las ciudades y de los conflictos locales: Filipo había sometido Grecia y preparaba la guerra contra Asia; también advirtió que los griegos estaban ya en una aventura cuyas dimensiones eran incapaces de imaginar.

La visión histórica de Teopompo fue la pauta de la nueva forma de escribir historia; en todos los historiadores posteriores, quedan vestigios de su influencia; sin embargo, dos son considerados sus herederos directos: Duris y Filarco, quienes, como aquél, tuvieron una visión dramática de los acontecimientos e hicieron retratos individuales de sus personajes: éstos tenían una vida plena, pública y privada. Sus obras abundan en peripecias, pequeños detalles, escenarios y hechos pintorescos; pero mientras Filarco busca el patetismo, Duris provoca efectos estéticos y teatrales. ${ }^{4}$

Duris de Samos, pues, es uno de los representantes de esta nueva concepción literaria de la historia, de la llamada "historiografía trágica" que, en términos generales y como su nombre lo indica, tiene algunas características en común con la tragedia: héroes y heroínas, cambios de fortuna, lecciones morales e incluso vestuario y escenografía; pero, más allá de eso, el historiador trágico busca envolver a su audiencia emocionalmente a fin de provocarle sentimientos intensos, cosa inimaginable entre los historiadores de la vieja guardia, donde lo más importante era la exaltación de las hazañas heroicas, de la virtud y de la patria.

\footnotetext{
3 "Ceux de Théopompe ont une vie privée, libre, sensuelle. Ils boivent, ils jouent, ils ont des maîtresses. Leur personnalité tout entière se dévoile et réagit sur leur activité politique", cf. Pédech, p. 9.

${ }^{4}$ Cf. Pédech, p. 9.
} 
Para la época en que Duris escribió sus historias, el significado de "patria" estaba algo lastimado, era el siglo siguiente a la guerra del Peloponeso: los griegos se hallaban obligados a aceptar cada vez más la manipulación externa, continuaban las luchas intestinas y ninguna ciudad era del todo autosuficiente; en cambio, el vecino reino persa se consolidaba cada vez más; por otra parte, Filipo y Alejandro consiguieron subyugar al pueblo griego que estaba dividido, y lograron imponer la hegemonía macedonia sobre toda la Hélade. La polis clásica había dejado de existir. ${ }^{5}$ Las condiciones estaban dadas para que lo más importante fuera el individuo.

Esta invasión macedonia quedó atestiguada en prácticamente todos los historiadores de la época; desafortunadamente la mayor parte de sus obras sólo se conserva en forma fragmentaria. No obstante, los esfuerzos por restaurar la historia de esa agitada era bajo su propia perspectiva continúan. Duris de Samos es uno de esos historiadores que, por ser una fuente esencial para la comprensión de la época, merecen ser estudiados.

Hay muy pocas cosas que pueden decirse sobre Duris con certeza; sin embargo, creo que vale la pena conocerlas, e intentar comprender su visión histórica a partir de los escasos

\footnotetext{
${ }^{5}$ La $\pi$ ó $\imath_{1 \varsigma}$ surgió en Grecia, teniendo como características principales la areté y la libertad. Pero con la llegada del helenismo y de los gobiernos monárquicos esta libertad fue cada vez menos plena: ya "desde el siglo v las poleis (por lo menos dentro de un marco regional y étnico coherente) eran capaces de renunciar a una parte de su soberanía para transferir las competencias de su defensa y de su política exterior a un gobierno federal, representativo y permanente", Will, p. 163; sin embargo, en el mundo helenístico la hegemonía no recaía ya sobre una ciudad (como Esparta o Atenas), sino sobre un solo hombre, Filipo de Macedonia —en este caso-; para el siglo III, todas las poleis griegas fueron territorio dominado por la hegemonía macedonia; "la ciudad griega se había derrumbado: no aguantaron aquellos cimientos platónicos — quizá utópicos ya desde su origen—”, Tapia Zúñiga, 1991-1992, p. 295. Al presentarse este derrumbamiento —quizá el de uno de los ideales más importantes de la cultura griega — vino lo inevitable: "el sistema de valores que había elaborado esa polis tiende a desvanecerse para dejar sitio a nuevas corrientes que privilegian al individuo frente a la comunidad", Will, p. 169.
} 
fragmentos y acontecimientos biográficos que existen sobre él: nació alrededor del año 330, cuando los samios estaban desterrados de la isla; ${ }^{6}$ se sabe que su padre fue tirano de Samos, ${ }^{7}$ posición que años después el mismo Duris ocuparía. ${ }^{8}$ Tuvo por lo menos dos hermanos, ${ }^{9}$ Linceo, poeta cómico, amigo de Menandro, y Liságoras, ${ }^{10}$ un político samio. El mismo Duris dice que es descendiente de Alcibíades. ${ }^{11}$

Otro dato importante sobre la vida de Duris es que terminó su educación en Atenas, donde fue discípulo de Teofrasto junto con su hermano Linceo. ${ }^{12}$ Aunque es difícil precisar la

\footnotetext{
${ }^{6}$ Es muy posible que Duris de Samos no haya nacido en Samos, y, aunque no exista ningún dato preciso al respecto, es muy posible que hubiera nacido en Sicilia: él fue el único historiador no siciliano que escribió una historia de Agatocles, tirano de Siracusa; cf. Kebric, 1972, p. 4.

${ }^{7}$ Cf. Willamowitz, p. 51, n. 2: "der Vater des Duris Tyrann gewesen sei".

${ }^{8}$ Se cree que la tiranía en Samos tenía una sucesión de padre a hijo; Willamowitz (ibidem) remite a Schwartz en $R K A$, s. v. Duris, col. 1853 "vielleicht nicht durch eigene Usurpation, sondern als Erbe seines Vaters". Esta sucesión se practicó en Samos más o menos hasta el año 281.

${ }^{9}$ Según Kebric (1974, p. 287) es posible que Duris fuera el hermano mayor, pues llevaba el nombre de su abuelo, y además sucedió a su padre en la tiranía de Samos.
}

${ }^{10}$ Barron, p. 191, n. 2, propone el siguiente árbol genealógico para la familia de Duris:

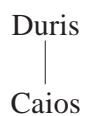

(nacido antes del 350, tirano después del 322)

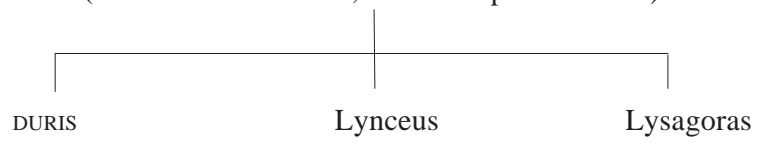

(historiador y tirano, vivo en 281) (poeta cómico) (activo c. 300)

${ }^{11}$ Cf. fr. 3 (Plu., Alk., 32). Esta aseveración de Duris posiblemente sea cierta: Alcibíades estuvo en Samos hacia el año 411 a. C. y tuvo un hijo con la reina de Esparta; tal vez el origen de Duris de Samos se remonte a esta unión, cf. Thuc., VIII, 86, 1; Plu., Alk., 26; 23, 7; Ages., 3, 1-2. Según Manni, es posible que el hijo de Alcibíades haya sido el abuelo de Duris, tomando en cuenta que entre cada generación hay aproximadamente 30 años de diferencia, cf. Manni, p. 168.

${ }^{12}$ Cf. fr. 1 (Athen., IV, 1, p. 128A). 
fecha exacta de su llegada a esa ciudad, ésta pudo ocurrir entre los años 304 y 302 aproximadamente. ${ }^{13}$ Ahí fue discípulo de Teofrasto en el Liceo, que no era solamente un círculo de reflexión filosófica, sino un centro de estudios literarios y científicos. ${ }^{14}$ Tal educación dejó una fuerte y extensa huella en la formación académica de Duris, quien escribió sobre una infinidad de temas; no obstante, los que más le interesaron fueron la literatura y el arte. Tales preferencias marcaron radicalmente su forma de escribir, su estilo narrativo está lleno de fuerza dramática y sentido estético, como si las historias contadas por él fueran una tragedia o una pintura. ${ }^{15}$

A la luz de estos datos biográficos sobre Duris, no es de extrañar la calidad de su formación:

la vida de Duris muestra un hombre cultivado, guiado por la erudición de la escuela peripatética, así lo confirman sus fragmentos. Sin embargo, él no es solamente un autor de libros: es un hombre político y conocedor de los personajes importantes de su tiempo: Antígono, Demetrio, Lisímaco y tal vez de algunos demagogos atenienses como Estratocles, Demócares y Lácares. Él tuvo la posibilidad de escribir su obra histórica a la luz de los acontecimientos. ${ }^{16}$

Duris, gracias a su posición privilegiada dentro de su ciudad, pudo contar con información política de primera mano.

La situación en Samos, cuando Duris terminó su formación y regresó a su patria, alrededor del año $300,{ }^{17}$ debió ser más o menos la siguiente: cuando los samios regresaron a su isla después de cuarenta años de exilio, se encontraron con muchas dificultades: el clima político estaba bastante agitado; los que

\footnotetext{
${ }^{13}$ Cf. Kebric, 1974, p. 287.

${ }^{14}$ Cf. Pédech, p. 262.

${ }^{15}$ Cf. Pédech, p. 263.

${ }^{16}$ Cf. Pédech, p. 264.

${ }^{17}$ Según Kebric, 1972, p. 6.
} 
consiguieron regresar ${ }^{18}$ eran los más ricos y por eso se optó por instaurar la plutocracia, ${ }^{19}$ que — de alguna manera- era también una tiranía. Por aquél tiempo, Caios, el padre de Duris y partidario de Antígono, ${ }^{20}$ fue impuesto como tirano de Samos. ${ }^{21}$ Aunque es muy difícil precisar con exactitud la fecha de su gobierno, hay que suponer que ésta tuvo que ocurrir después del año 322, año del retorno, y que posiblemente haya terminado en el año 301 con la batalla de Ipsos y la muerte de Antígono.

Es posible que Duris haya tomado el poder a su regreso a su tierra, y que su gobierno haya durado hasta el $281,{ }^{22}$ año en que la isla pasó a la hegemonía de Ptolomeo II, ${ }^{23}$ y que, de alguna manera, marcó el término de la historia local de Samos. Desgraciadamente no se conservan más datos acerca de la tiranía de Duris.

18 "The poorer classes outside the inmediate vicinity could not afford the move unless subsidized by the newly-reinstitued government or sympathetic friends, and others had undoubtedly become so firmly entrenched elsewhere (inscriptions show that Samians were spread all over the Mediterranean) that returning was neither feasible nor desirable. The core of the first returnees, then, would presumably have been made up of those with money, who, with few exceptions, were former landowners or their descendants, anxious to reclaim lost properties", cf., ib., p. 7.

${ }^{19} \mathrm{La}$ plutocracia (el gobierno de los más ricos) fue una influencia de la política macedonia, que también llegó a Atenas después de la guerra sacra en el 321; cf. Kebric, ibid.

${ }^{20}$ Antígono, como Casandro, era uno de los diádocos. Samos le ofreció su base naval a Demetrio Poliorquetes, el hijo de Antígono; se instituyeron fiestas en honor de Antígono y sus hijos; una tribu fue llamada Demetria, y los samios sirvieron en la armada de Antígono. Cf. Diod., XIX, 62, 7; XX, 50, 4; Habicht, 1956, p. 62.

${ }^{21}$ Es posible que Caios se hubiera ganado ese cargo por haber sido vencedor en los juegos olímpicos (cf. fr. 4), lo cual seguramente le generó una gran popularidad entre sus compatriotas que lo tomaron como líder político; cf. Kebric, 1972, p. 8.

${ }^{22}$ En este año se dio la batalla de Ciropedion, en la que Lisímaco, el protector en turno de Samos, murió.

${ }^{23}$ Difícilmente Ptolomeo hubiera podido dejar margen alguno para un gobierno independiente en Samos, pues escogió sus puertos para establecer la base de la flota egea. 
Quizá esta serie de eventos (el fin de su tiranía, la muerte de Lisímaco, la llegada de Ptolomeo) incitaron a Duris a escribir su obra histórica: cuando Duris volvió a su patria en su juventud lo hizo como un ardiente nacionalista, ${ }^{24}$ seguramente por la nostalgia de una patria que no conocía, pero ya estando ahí se dio cuenta de que su patria poco a poco se convertía en una colonia macedonia más, $\mathrm{y}$, sobre todo, de que los protectores de Samos, Antígono, Demetrio y Lisímaco, no eran más que macedonios protegiendo la isla de otros macedonios con intereses distintos.

Duris entonces se encontró con muchas razones para escribir, y seguramente pasó los últimos años de su vida escribiendo: en una edad en la cual un hombre comienza a disfrutar los frutos de su vida, él fue depuesto de la tiranía de Samos, su carrera política había concluido. Obviamente, su obra es una denuncia de cómo los macedonios acabaron con su patria, pero también fue escrita, a la manera de Tucídides, como una advertencia para que las futuras generaciones aprendieran de los errores del pasado. ${ }^{25}$

Sin embargo, no existen noticias sobre sus últimos años de vida ni sobre la fecha o el lugar de su muerte; pero, si ponemos atención al destino de Samos, es muy probable que haya muerto "como un hombre desilusionado". ${ }^{26}$

\section{Producción bibliográfica}

Duris, más que historiador, fue un polígrafo: ${ }^{27}$ escribió acerca de diversos temas, sobre todo, acerca de asuntos relacionados

\footnotetext{
${ }^{24}$ Duris escribió una crónica de su patria, y Plutarco lo acusó de distorsionar la verdad en nombre de los intereses de Samos. Cf. fr. 67 (Plu., Per., 28, 1-3).

${ }^{25}$ Cf. Kebric, 1972, p. 47.

${ }^{26}$ En Kebric, id., p. 9.

${ }^{27}$ Cf. Pédech, p. 265.
} 
con el arte y la literatura. De su producción literaria sólo quedan unos cuantos fragmentos de sus tres grandes obras históricas: Historias macedonias, En torno a Agatocles y Los anales de Samos, y otros de algunas obras menores: 1) Sobre temas literarios: Problemas homéricos, Acerca de las tragedias y Acerca de Eurípides y Sófocles; 2) sobre temas artísticos: Acerca de las pinturas, Acerca del entallar, Acerca de las leyes y Acerca de las competencias. Estos dos últimos libros posiblemente trataban acerca de certámenes musicales; Jacoby, hablando de Acerca de las leyes, afirma que "probablemente el libro no sea ni un compendio de leyes musicales, ni un suplemento a los XXIV libros De las leyes de los estoi$\cos$ de Teofrasto, sino una historia de la música". ${ }^{28}$

\section{Los fragmentos}

En conjunto, los fragmentos de Duris son como algunas de nuestras revistas modernas, quincenales o mensuales, ilustradas y entretenidas y eruditas: se habla sobre una gran cantidad de temas, pero al finalizar, aunque uno se haya entretenido bien, se tiene la impresión de que no se conoció suficientemente ninguna historia. A pesar de que al terminar la lectura queda la satisfacción de que uno aprendió "algo" acerca del mundo griego antiguo, lo que más se queda es el disfrute de la lectura en sí, y las anécdotas que se mezclan con cada historia (¡ojalá que mi traducción conserve un poco de ese deleite!).

Hay un gran debate en torno a esta fragmentaria obra de Duris: sus estudiosos se cuestionan acerca de la autenticidad y de la calidad de sus escritos. Normalmente, a la luz de sus fragmentos, la mayoría de los críticos la condenan demasiado

\footnotetext{
28 "Das buch ist vermutlich weder eine zusammenstellung von vó $\mu \mu \alpha(C$

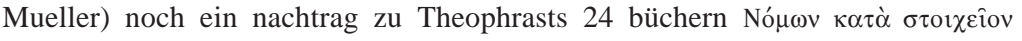
("über rechtswissenschaft" Beloch), sondern musikgeschichtlich", en Jacoby, Kommentar, p. 122, n. 27.
} 
rápido; muy pocos son los que — como yo- le tienen alguna estima, pero no tengo competencia ni en historia ni en estilística griega, para hablar con autoridad sobre el tema; sin embargo, me alegra saber que hay estudiosos que pueden hablar y afirmar algo de lo que siento, como Beloch quien dice que Duris "en su tiempo, fue el autor más importante y el que tuvo mayor influjo". ${ }^{29}$ La mayoría de las discusiones acerca de Duris y de su obra se han centrado en el estudio de la "historiografía trágica" y en el problema de establecer las fuentes de la Biblioteca histórica de Diodoro. Los estudios para entender la obra de Duris por sus propios méritos son escasos; sólo contamos con el de Pédech, con el de Kebric y con el de Ferrero, menos exhaustivo. ${ }^{30}$

Más allá de los juicios acerca de su obra, es innegable que Duris fue un autor muy consultado en la antigüedad; así lo indica el hecho de que haya sido preservado por tantos escritores que utilizaron sus escritos: Cicerón, en el s. I a. C., era un admirador de su obra; ${ }^{31}$ Dídimo, el poeta alejandrino, consultó su historia sobre Filipo; ${ }^{32}$ Diodoro incorporó pasajes de Duris en su Biblioteca histórica, ${ }^{33}$ Estrabón empleó sus etimologías. ${ }^{34}$ Al final del s. I d. C., Plinio se refirió a él en muchas ocasiones; ${ }^{35}$ Plutarco extrajo información de Duris para sus Vidas paralelas y para sus Tratados morales; ${ }^{36}$ Zeno-

\footnotetext{
${ }^{29}$ En p. 479: "den bedeutendsten und einflußreichsten Historiker seiner Zeit".

${ }^{30}$ Pédech, Trois historiens méconnus: Théopompe, Duris, Phylarque; Kebric, In the shadow of Macedon: Duris of Samos; Ferrero, "Tra poetica ed istorica: Duride di Samo".

${ }^{31}$ Cf. fr. 73 (Cic., ad Att., VI, 1, 18).

${ }^{32}$ Cf. fr. 36 (Didym., de Demosth. [Berl. Klass.-T I], 12, 50).

${ }^{33}$ Cf. Diod., XVII, 23, 2; XVIII, 8, 7; 18, 6; 56, 7; XIX, 2, 9; 44, 4-5; 58, 2-4; 62,$7 ; \mathrm{XX}, 40,6 ; 41 ; 46,2-3 ; 53,1-4 ; 92,4 ; 104$.

${ }^{34}$ Cf. fr. 54 (Strab., I, 3, 19).

35 Cf. fr. 12 (Plin., HN, I, 7 a-e); fr. 32 (-, -, XXXIV, 61); fr. 43 (-, -, XXXVI, 79); fr. 48 (-, -, VII, 30); fr. 55 (-, -, VIII, 143).

${ }^{36}$ Cf. fr. 8 (Plu., Per., 28); fr. 38 (-, Dem., 19); fr. 39 (-, -, 23); fr. 40 (-, Alex., 15); fr. 46 (-, -, 46); fr. 50 (-, Phoc., 4); fr. 51 (-, -, 17); fr. 53 (-, Eum.,
} 
bio, de la época de Adriano, tomó sus proverbios, ${ }^{37}$ Clemente de Alejandría ${ }^{38}$ conoció su obra; Ateneo ${ }^{39}$ alabó sus vívidas descripciones. El lexicógrafo Harpocratión ${ }^{40}$ y Diógenes Laercio $^{41}$ lo utilizaron; Porfirio leyó en él detalles acerca de los filósofos; ${ }^{42}$ Proclo, ${ }^{43}$ en el s. v d. C., lo consultó para criticar a Platón. En el s. vi d. C., Estéfano de Bizancio ${ }^{44}$ obtuvo de él información acerca de Samos, Egipto y Sicilia. Focio ${ }^{45}$ lo estudió en el s. IX d. C.; la $S u d a^{46}$ se sirvió de él en el s. x d. C., $\mathrm{y}$ algunos escoliastas como Tzetzes ${ }^{47}$ conocieron su obra a finales del s. XII de nuestra era. Posiblemente tuvo alguna

1); fr. 67 (-, Per., 28); fr. 69 (-, Ages., 3); fr. 70 (-, Alk., 32); fr. 71 (-, Lys., 18); fr. 84 (-, Prov., I, 48).

${ }^{37}$ Cf. fr. 63 (Zen., Prov., V, 64); fr. 95 (-, -, II, 26); fr. 96 (-, -, -, 28).

${ }^{38}$ Cf. fr. $41^{\text {a }}$ (Clem. Alex., Strom., I, 139, 4, p. 86, 21 Stä).

${ }^{39}$ Cf. fr. 1 (Athen., IV, 1, p. 128 A); fr. 2 (-, VIII, 18, p. 337 D); fr. 2 (-, XIII, 10, p. 560 B); fr. 3 (-, VI, 55, p. 249 CD); fr. 4 (-, IV, 63, p. 167 CD); fr. 5 (-, X, 45, p. $434 \mathrm{EF}$ ); fr. 7 (-, XIII, 85, p. $606 \mathrm{CD}$ ); fr. 10 (-, XII, 60, p. 542 B-E); fr. 12 (-, IV, 42, p. 155 C); fr. 13 (-, VI, 63, p. 253 D-F); fr. 14 (-, XII, 50, pp. 535 E-536 A); fr. 15 (-, -, 66, p. 546 CD); fr. 16 (-, XIV, 9, p. 618 BC); fr. 18 (-, XIII, 84, p. 605 DE); fr. 19 (-, XII, 59, p. 542 A); fr. 26 (-, XV, 52, p. 696 E); fr. 28 (-, XIV, 40, p. 636 F); fr. 29 (-, IV, 84, p. 184 D); fr. 35 (-, XII, 43, p. 532 DF); fr. 37a (-, VI, 19, p. 231 BC); fr. 37b (-, IV, 42, p. 155 D); fr. 42 (-, XII, 38, p. 529 A); fr. 49 (-, I, 31, p. 17 F); fr. 52 (-, XIII, 10, p. 560 F); fr. 57 (-, I, 35, p. $19 \mathrm{EF})$; fr. 60 (-, XII, 30, p. $525 \mathrm{EF})$; fr. 72 (-, XI, 111, p. $504 \mathrm{~B})$.

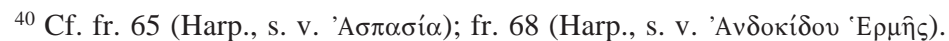

${ }^{41}$ Cf. fr. 22 (Diog. Laer., I, 119-120); fr. 31 (-, -, 38); fr. $74(-,-, 22)$; fr. 75 $(-,-, 74)$; fr. $76(-,-, 82)$; fr. $77(-,-, 89)$; fr. 78 (-, II, 19).

${ }^{42}$ Cf. fr. 23 (Porphyr., Vit. Pyth., 3).

${ }^{43}$ Cf. fr. 83 (Procl., In Plat. Timae., I, 90, 20 Diehl).

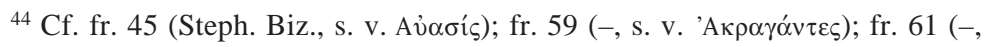
s. v. Гó $\rho \gamma \nu \rho)$.

${ }^{45}$ Cf. fr. 9 (Phot., Bibl., 176, p. 121b 3); fr. 1 (-, -, -, 121a 41); fr. 17 (Phot.-

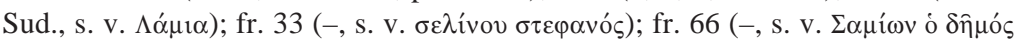

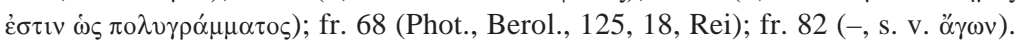

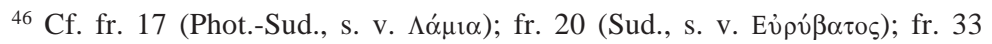

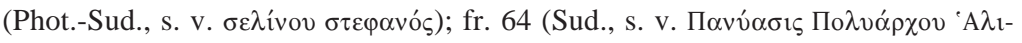

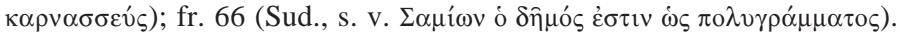

${ }^{47}$ Cf. fr. 41b (Tzetz., Posthom., 770); fr. 56b (-, Lykophr., 1378); fr. 92 (-, $102,143,183)$. 
influencia en Filarco, Nepote, Quinto Curcio, Lucano, Arriano, Polieno y otros. ${ }^{48}$ Con todo esto es evidente la importancia que Duris tuvo en la antigüedad y la edad media: ¡más de mil trescientos años de vigencia!

Desafortunadamente esa subsistencia de las obras de Duris, no sirve para determinar la "calidad" de su contenido histórico; dependemos enteramente de los escritores que nos lo han transmitido. Los juicios sobre el trabajo de Duris surgieron doscientos años después de su redacción: Dídimo lo acusa de ser exagerado ${ }^{49}$ pero Cicerón, el más reconocido de todos los críticos, se refiere a él como homo in historia diligens, ${ }^{50}$ mostrando su familiaridad con la obra de Duris, muy vigente entre la elite literaria de Roma. ${ }^{51}$ Resulta muy complicado juzgar el trabajo del historiador a partir de unos cuantos fragmentos y juicios sobre su producción histórica; la variedad en la opinión de los críticos sólo demuestra cómo las preferencias históricas cambian de acuerdo con cada época.

\section{El estilo historiográfico}

La historiografía trágica es un legado de la escuela peripatética. Aristóteles fue el primero en hacer una comparación entre poesía e historia; de acuerdo con su teoría, la poesía es más filosófica que la historia porque presenta los acontecimientos "como deberían ser" y no "como son". ${ }^{52}$ Evidentemente, si hubo necesidad de establecer las diferencias entre poesía e historia, fue porque ya existía una confusión entre ambas; así, no podemos decir que, con la llegada de esta "nueva" forma de contar la

\footnotetext{
${ }^{48}$ Cf. Kebric, 1972, pp. 10-11.

${ }^{49}$ Cf. fr. 36.

${ }^{50}$ Cf. fr. 73.

${ }^{51}$ Cf. Kebric, 1972, p. 13.

${ }^{52}$ Cf. Arist., Poet., IX, 1451b $1 \mathrm{s.}$
} 
historia, alguien haya "inventado" el género: en Heródoto ya existían ingredientes para la historiografía trágica. ${ }^{53}$

En realidad, la confusión surgió desde el principio, porque la historia y la tragedia tuvieron como origen común a la epopeya. ${ }^{54}$ La historiografía peripatética tiene mucho que ver con la tragedia clásica: la vida es representada como una tra-

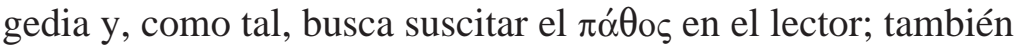
a la manera clásica, en este tipo de historia hay $\mu$ í $\mu \eta \imath \iota$, una

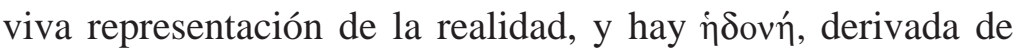

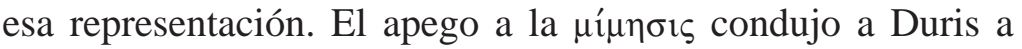
crear escenarios muy realistas (para muestra sirvan los fragmentos 10, 13 y 14), cosa que Diodoro deja a la entera imaginación del lector. Para Duris, la historia también es como una pintura; por eso, la descripción tiene que ser precisa, para poder cautivar la sensibilidad y la imaginación del lector. ${ }^{55}$ Esta carencia de placer estético en la lectura era lo que él criticaba de las obras de Éforo y Teopompo: ${ }^{.56}$ la historia también es un tipo de literatura y debe producir algún deleite en quien la lee. ${ }^{57}$

La forma de escribir de Duris también seguía una línea más o menos teatral, en la que el vestuario de los personajes y los escenarios jugaban un papel importante, y, aunque parezca increíble, en sus historias a veces existía el acompañamiento musical: en el fragmento 70, Alcibíades regresa a Atenas y los

\footnotetext{
${ }^{53}$ Cf. Lesky, pp. 324-325.

${ }^{54}$ Cf. Pédech, p. 369.

55 Cf. Pédech, p. 372.

${ }^{56} \mathrm{Cf}$. fr. 1.

57 Véase también Jacoby, Kommentar, p. 117: “D. entwickelte jedenfalls das programm der tragischen historie, das Schwarz als "übertragung der aristotelischen poetik und stillehre auf die geschichtsschreibung" bezeichnet ... die forderung ging

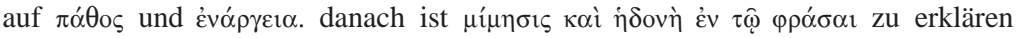
als 'dramatische anschaulichkeit und (daraus entspringende) ergötzung des lesers'

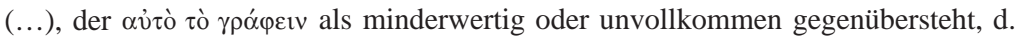
h. Die 'nimis anxia de verborum compositione sedulitas ...'" (sic).
} 
remeros son acompañados por música de flauta ${ }^{58}-\mathrm{y}$ una vez más, Duris sorprende al lector con la imagen de la armoniosa simetría entre la música y el movimiento de los remos.

Tal vez estaría bien aplicar el epíteto de "barroco" al estilo de Duris de Samos, como al estilo que dominó el arte europeo de los s. XVII y XVIII d. C., pues el de Duris, como el estilo barroco, busca remover la sensibilidad. En las obras de Duris existe cierta ruptura con el mundo clásico, encarnado en el aticismo; tal vez ésa sea la causa de la pérdida de su obra, criticada por los autores neo-aticistas.

Antes de hacer alguna otra consideración con respecto a la producción histórica de Duris, conviene recordar que él tuvo razones personales para escribir sus historias: vivió tiempos políticos muy difíciles antes de, y durante su gobierno; tal vez esto haya tenido un poco que ver con sus conceptos historiográficos, quizá todo lo que él vivió sirvió para que pusiera más atención al lado "trágico" de la vida humana. ${ }^{59}$

Los personajes preferidos por Duris fueron aquellos que se encontraban en el poder y estaban atormentados por cualquier tipo de pasión, o los dominados por algún defecto de carácter; ello resulta lógico, si se piensa que, de alguna manera, sus escritos reflejan las tendencias literarias de la época: el mundo griego se estaba desmoronando poco a poco.

Muchas veces la obra de Duris tiene intenciones moralizantes $;{ }^{60}$ para lograr ese efecto, buscaba y ponía como ejemplo a los peores personajes posibles; en el fragmento 10, Demetrio de Falero es condenado por su extravagancia: mientras él ordena la vida de los otros, es incapaz de poner la suya en orden; ${ }^{61}$

\footnotetext{
${ }^{58}$ Cf. Pédech, p. 377.

${ }^{59}$ Cf. Kebric, 1972, p. 18.

60 "Los rasgos predominantes de su escritura no fueron el escándalo sino 'el mito, la anécdota, las lecciones morales, las historias maravillosas, los proverbios, la poesía y la etimología' ", en Shipley, p. 286.

${ }^{61}$ Mastrocinque sostiene que Duris es en gran medida responsable de la desfavorable imagen de Demetrio I como rey trágico.
} 
en el fragmento 42 muestra su indignación por la situación de Sardanápalo, el rey de Asiria. Los gobernantes macedonios eran los preferidos por Duris para ejemplificar los defectos más atroces; en cambio, los griegos le servían como modelo de virtud; entre estos personajes virtuosos los preferidos de Duris eran Foción, Eumenes, Arcadio el aqueo y Cares de Atenas.

Entre los personajes siniestros, sus preferidos fueron Agatocles, un personaje ideal para la historiografía trágica, totalmente sanguinario y con una absoluta carencia de escrúpulos; ${ }^{62}$ Demetrio Poliorquetes, con una vida llena de desórdenes, de escandalosas aventuras, de actividad desbordante — grandes ambiciones, personalidad múltiple, hijo afectuoso, amante insaciable - era un personaje de tragedia; ${ }^{63}$ Duris lo entendió y narró su vida como una representación trágica. Demetrio de Falero y Alcibíades también fueron personajes de excesos que historiográficamente fascinaron a Duris.

Este historiador "trágico" se preocupó por delimitar muy bien los caracteres de sus personajes: hizo retratos individuales de cada uno; recordemos que la biografía era un género que cobraba cada vez más popularidad, pero también era un género con poca credibilidad, ya que el criterio del biógrafo siempre era el punto de partida. Sin embargo, Duris, como Teopompo, pensaba que el conocimiento de los hombres es el fundamento de la política; ${ }^{64}$ por eso, Duris intentaba aproximarse lo más posible a la personalidad de cada dirigente.

Podría decirse que Duris fue un historiador moralista con un profundo sentido patriótico, un escritor que atestiguó de

\footnotetext{
${ }^{62}$ Cf. Pédech, pp. 311 y 380.

${ }^{63}$ Cf. id., p. 355; Mastrocinque, pp. 269-276.

${ }^{64}$ Pédech, p. 382: “Si Duris accorde beaucoup d' importance à l'extérieur de ses personnages, il n'a pas négligé l'analyse des caractères et la peinture des sentiments. Un élève de Théophraste ne pouvait pas s'en abstenir et le tyran de Samos n'ignorait pas que la connaissance des hommes est le fondement de la politique".
} 
primera mano los efectos del dominio macedonio. El resentimiento que le dejó la presencia de las tropas macedonias en Samos lo hizo volver la cabeza hacia sus ideales representados por Foción, Eumenes y Demóstenes. ${ }^{65}$

\section{Juicios sobre la obra histórica de Duris de Samos}

Después de haber leído los fragmentos, queda la impresión de que los críticos literarios de todos los tiempos han sido muy severos al juzgar la obra de Duris: Plutarco lo acusó de su tendencia a "dramatizar" los acontecimientos ${ }^{66}$ sin embargo, lo usó muchas veces como fuente. Los autores modernos no han sido más indulgentes: Wachsmuth considera que Duris antepone el estilo a la veracidad histórica; ${ }^{67}$ Schubert lo trata de historiador miserable y falto de seriedad. ${ }^{68}$ Los juicios son muy severos.

No obstante, es muy significativo que su obra haya sido consultada por tantos historiadores que lo sucedieron; tal vez, al menos, las Historias de Duris hayan motivado el estudio de la historia griega. Duris venía de una familia política y, como tirano de Samos, tenía que entender la naturaleza local e internacional de la política; su cercanía con los personajes más poderosos de la época tuvo que ser un factor determinante en la observación de la política; era un hombre muy educado - y educado en la literatura-: la infinidad de temas que trató son una prueba de su vasta erudición. ${ }^{69}$

\footnotetext{
${ }^{65}$ Cf. Kebric, 1972, p. 23.

${ }^{66}$ Cf. fr. 8 (Plu., Per., 28, 3).

${ }^{67}$ Cf. Wachsmuth, Einteilung ..., pp. 544-546.

${ }^{68}$ Cf. Schubert, Quellen ..., pp. 60-62.

69 “Altre caratteristische di Duride ... l'interesse all'erudizione (tanto che era consultato da un erudito come Plinio), l'amore per i racconti drammatici, le favole interessanti, i miti, i proverbi, dei quali voleva dare una spiegazione, e per le favole etiologiche", cf. Dolce, p. 140.
} 
Sin embargo, Duris estuvo seriamente afectado por la conquista macedonia; su obra es un reflejo de la frustración y el resentimiento, de la lucha de los conservadores contra el cambio; a pesar de esto, supo combinar tanto el pasado como el presente, y produjo historias que le fascinaban al público en general, que seguramente estaba más interesado en escuchar una buena historia que en las exhortaciones morales ${ }^{70}$ Duris, al hacer historia, se cuidaba de complacer las demandas de un público que pedía más entretenimiento que instrucción. ${ }^{71}$

Tal vez el mayor defecto del historiador Duris, sea el no haber sabido refrenar sus propias emociones al describir los acontecimientos, que le eran tan cercanos, y posiblemente por eso no esté considerado entre los grandes historiadores de la antigüedad. La condena casi unánime a su obra fue el factor de que sus Historias no se tomaran en cuenta, de que se perdieran y se redujeran a unos fragmentos, a partir de los cuales resulta imposible averiguar el valor literario que se merecen. Es posible que Duris no haya sido un "gran" historiador; pero, sin duda — creo-, fue un gran artista.

Este estudio introductorio, al cual podría haber llamado "mis apuntes sobre Duris de Samos", pretende acompañar al texto original y a su versión al español; pero no pretende ser un trabajo exhaustivo. La traducción es eso, una traducción: mi traducción; me esforcé por no decir mal lo que se lee, a veces no muy bien, en el original. Ahí está el texto griego, cada quien puede hacer la suya. El texto está tomado de la edición de Jacoby (Fragmente der griechischen Historiker, pp. 136-158), con la salvedad de que suscribí las iotas que en el texto aparecen adscritas. Para la translación de los nombres propios al español, me ceñí a lo que dicta Errandonea en la

\footnotetext{
${ }^{70}$ Cf. Kebric, 1972, p. 81.

${ }^{71}$ Cf. id., p. 82.
} 
introducción de su Diccionario: el uso y la tradición son definitivos, la cantidad vocálica también lo es.

Dado el carácter sorprendente de lo que nos cuenta Duris de Samos, el juicio sobre la veracidad de sus historias le corresponde al lector. 

DURIS DE SAMOS

TESTIMONIOS Y FRAGMENTOS

Textos griego y español 


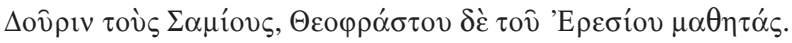

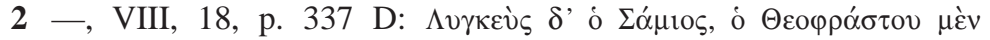

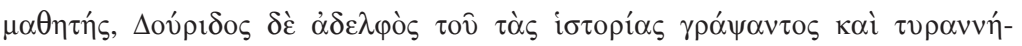

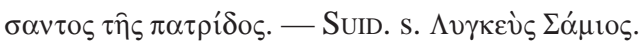

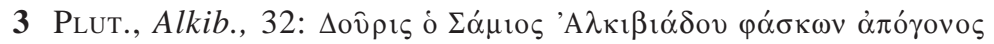
عîvar ... (F 70).

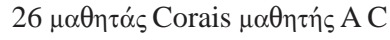


1 Ateneo, IV, 1, p. 128 A: En los tiempos ... de los samios Linceo y Duris, discípulos de Teofrasto, el eresio.

2 -, VIII, 18, p. 337 D: Linceo de Samos, discípulo de Teofrasto y hermano de Duris el que escribió las historias y fue gobernante de su

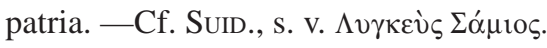

3 Plutarco, Alcibíades, 32: Duris de Samos, que afirma ser descendiente de Alcibíades ... (fr. 70). 


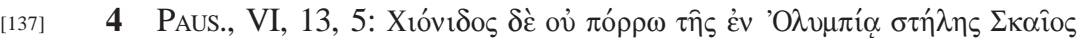

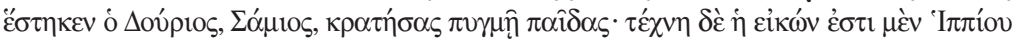

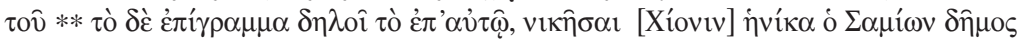

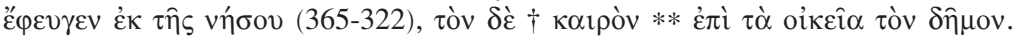

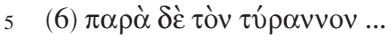

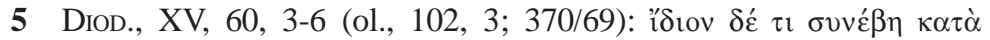

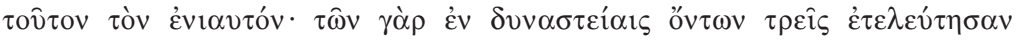

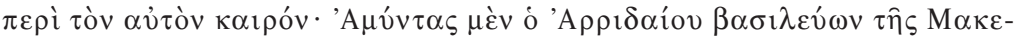

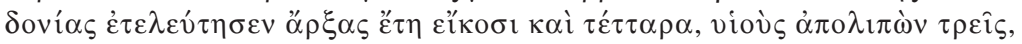

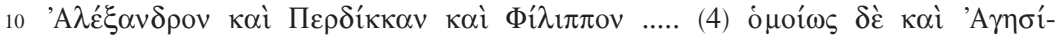

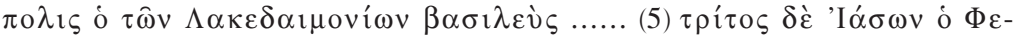

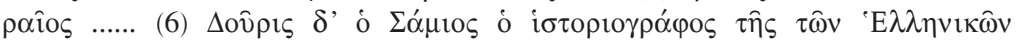

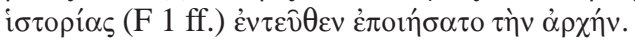

6 Cic., ad Att., VI, 1, 18: Duris Samius, homo in historia diligens 15 ... (F 73).

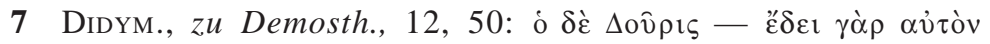
$\kappa \alpha \dot{v} \tau \alpha \hat{v} \theta \alpha \tau \varepsilon \rho \alpha \tau \varepsilon v ́ \sigma \varepsilon \sigma \theta \alpha \imath-\ldots .$. (F 36).

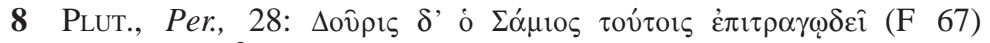

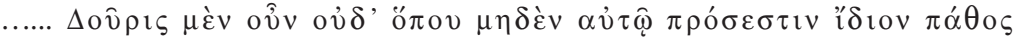

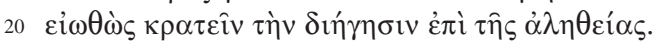

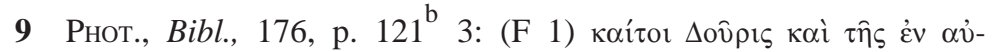

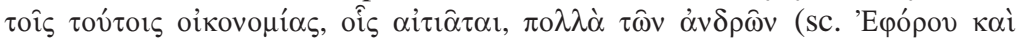

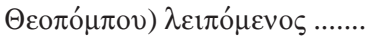

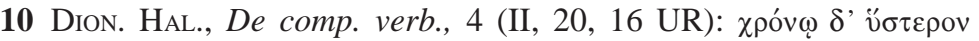

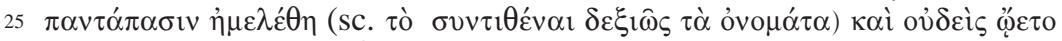

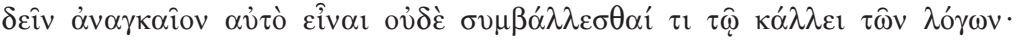

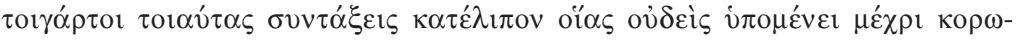

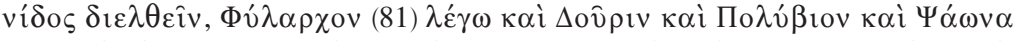

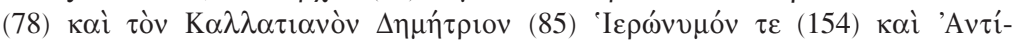

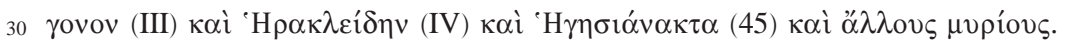

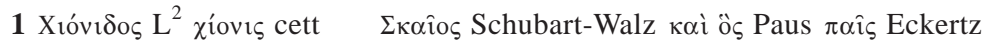

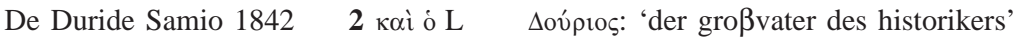

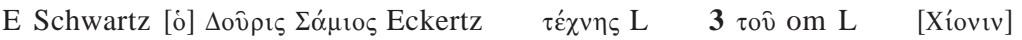

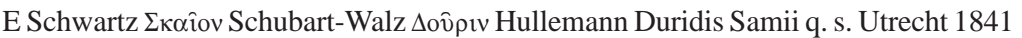

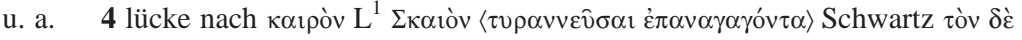

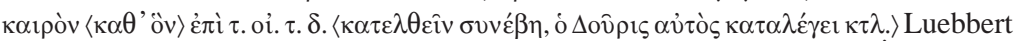
De Pindari poetae etc. Bonn $1886 \quad 5$ túpavvov: i. e. Skaios

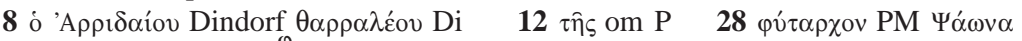

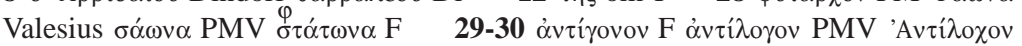

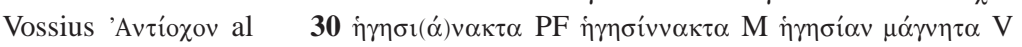


4 Pausanias, VI, 13, 5: No muy lejos de la estela de Quionis, en Olim- [137] pia, se encuentra Caios de Samos, el hijo de Duris, triunfador en el pugilato infantil. La estatua es obra de Hipias, hijo de ** La inscripción sobre él dice que consiguió su triunfo cuando el pueblo de Samos estaba desterrado de su isla (365-322 a. C.), y que la $\dagger$ Caios ** el pueblo a su patria. En tiempos del tirano ...

5 Diodoro, XV, 60, 3-6 (ol., 102, 3; 370/69): Algo peculiar ocurrió durante ese año; de los que estaban en el poder, tres murieron por el mismo tiempo. Amintas, el hijo de Arrideo, que reinaba en Macedonia, murió habiendo gobernado durante veinticuatro años, y dejando tres hijos, Alejandro, Perdicas y Filipo ... Igualmente Agesípolis, rey de los lacedemonios ... El tercero fue Jasón el fereo ... A partir de allí comienza sus Historias griegas Duris de Samos, el historiógrafo.

6 Cicerón, Cartas a Ático, VI, 1, 18: Duris de Samos, hombre diligente en historia ... (fr. 73).

7 Dídimo, Sobre Demóstenes, 12, 50: Duris —que necesariamente también aquí exagera- ... (fr. 36).

8 Plutarco, Pericles, 28: Duris de Samos dramatiza en estas cosas ... (fr. 67) Pues Duris no acostumbra ceñir su relato a la verdad, ni siquiera cuando no le afecta alguna pasión personal.

9 Focio, Biblioteca, 176, p. 121b, 3: (fr. 1) Y no obstante, Duris, incluso en cuanto a la dispositio que hay en los mismos, se queda muy atrás de estos hombres (de Éforo y de Teopompo) a los que critica ...

10 Dionisio de Halicarnaso, De la composición de las palabras, 4 (II, 20, 16 UR): Tiempo después, se descuidó del todo (sc. ordenar armónicamente las palabras), y nadie creía que ello fuera necesario, ni que contribuyera en mucho a la belleza literaria; y precisamente por eso nos dejaron unos escritos tales que nadie aguanta leer hasta el final: hablo de Filarco, Duris, Polibio, Psaón, Demetrio el calatiano, Jerónimo, Antígono, Heráclides, Hegesianacte y otros muchísimos. 


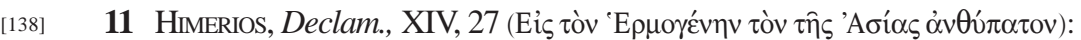

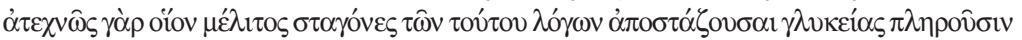

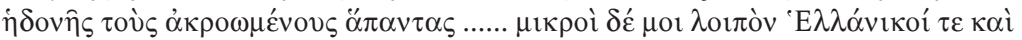

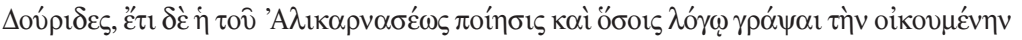

$5 \sigma \pi \mathrm{O} \delta \dot{\eta} \dot{\varepsilon} \gamma \varepsilon \dot{\varepsilon} v \varepsilon \tau$......

12 a) Plin., NH, I, 7: continentur ... prodigiosi partuus (s. 3) ... ex ... Onesicrito $(\S 28)$, Clitarcho $(\$ 29 ; 30)$, Duride $(\S 30=\mathrm{F} 48)$, ..... b) —, I, 8: continentur ... canum natura (s. 61-63) ... ex ... Ctesia ( $\$ 75 ; 107 ?)$, Duride $(\S 143=$ F 55), Philisto $(\S 144)$..... c) I, 12. 13:

10 continentur arborum naturae ... ex Callisthene, Isigono, Clitarcho, Anaximene, Duride (-), Nearcho, Onesicrito (§ 34) ..... d) I [33]. 34: continentur metallorum naturae .... ex ... Menaechmo qui de toreutice scripsit, Xenocrate qui item, Antigono qui item, Duride qui item (34, 61 = F 32) e) I, 36: continentur ... pyramides ... ex Alexandro Poly15 histore $(\$ 78) \ldots$. Duride $(\S 78=$ F 43) ... s. 63 F 10.

F

(T 5. F 36-55. 88? 92?)

\section{MAKE $\triangle O N I K A(I \Sigma T O P I A I)$}

\section{$\overline{\mathrm{A}}$}

20

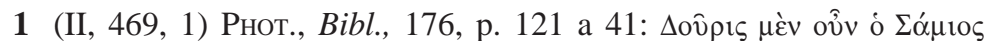

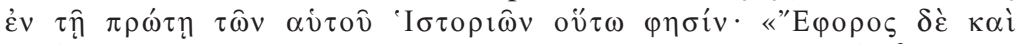

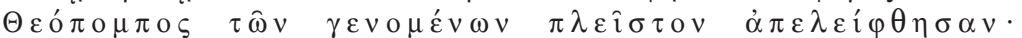

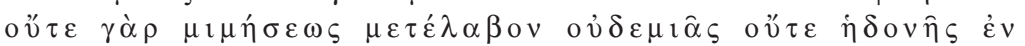

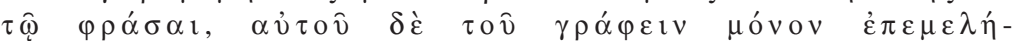
${ }_{25} \theta \eta \sigma \alpha v_{.} \gg($ folgt T 9)

$\overline{\mathrm{B}}$

2 (2) Athen., XIII, 10, p. 560 B: .... ö

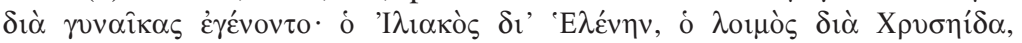

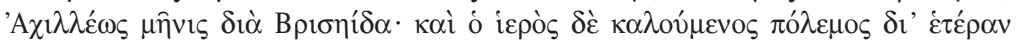

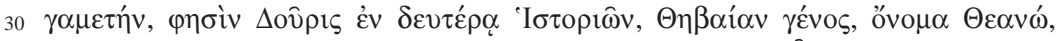

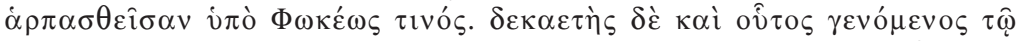

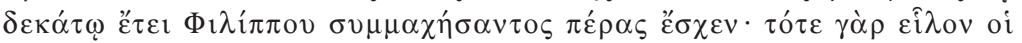

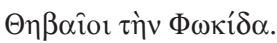

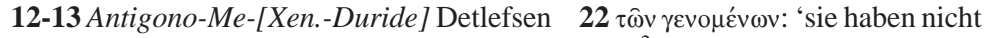
geschichte zu schreiben verstanden' Blass Att. Beredts. ${ }^{2}$ II, 409, 3 'longo intervallo post ipsius vitae veritatem relicta expositio' Scheller De hellenist. hist. conscr. arte

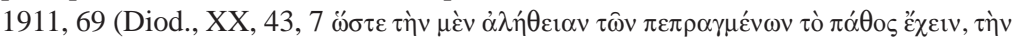

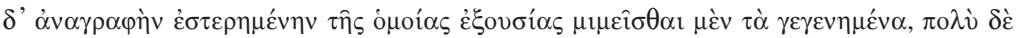
$\lambda \varepsilon i ́ \pi \varepsilon \sigma \theta \alpha \imath \tau \hat{\jmath} \varsigma \dot{\alpha} \lambda \eta \theta 0 \hat{\varsigma} \sigma v v \theta \varepsilon \dot{\sigma \varepsilon} \omega \varsigma)$. 
11 Himerio, Declamaciones, XIV, 27 (A Hermógenes, procónsul de [138] Asia): Sin artificios, como gotas de miel que brotan de sus discursos, éstos llenan de placer a todos los que escuchan ... Y pequeños, los Helánicos y los Duris, son algo que me queda pendiente y, además, la obra del halicarnaseo y todos aquellos en quienes, con la palabra, nació el deseo de describir la tierra habitada ...

12 a) Plinio, Historia natural, I, 7: Contenido: ... nacimientos prodigiosos ... de ... Onesicrito, Clitarco, Duris, ... b) - , I, 8: Contenido: ... naturaleza de los perros ... de ... Ctesias, Duris, Filisto ... c) I, 12, 13; Contenido: las naturalezas de los árboles ... de Calístenes, Isígono, Clitarco, Anaxímenes, Duris, Nearco, Onesicrito ... d) I [33], 34: Contenido: las naturalezas de los metales ... de ... Menecmo, quien escribió del arte de esculpir en bajorrelieve, de Jenócrates, de Antígono y de Duris que hicieron lo mismo e) I, 36: Contenido: ... las pirámides ... de Alejandro Polihistor ... de Duris ...

\section{Fragmentos}

\section{HISTORIAS MACEDONIAS}

(T 5. F 36-55. 88? 92?)

\section{Libro I}

1 (II, 469, 1) Focio, Biblioteca, 176, p. 121a, 41: En el libro I de sus Historias macedonias, Duris de Samos dice así: "Éforo y Teopompo se quedaron muy atrás de los historiadores que ha habido; en efecto, en su discurso no tuvieron imitación poética ni dulzura, sino que únicamente se dedicaron a cultivar el estilo" (viene del testimonio 9).

\section{Libro II}

a. 357/6 2 (2) Ateneo, XIII, 10, p. 560 B: ... Que incluso las guerras más grandes tuvieron lugar por culpa de las mujeres: la troyana por Helena, la peste por Criseida, la cólera de Aquiles por Briseida, y la llamada guerra sagrada, como dice Duris en el libro II de las Historias macedonias, por otra mujer casada, de origen tebano, llamada Teano, que fue robada por algún focio. Esta guerra que también fue de diez años, llegó a su final en el año décimo, cuando Filipo peleó como aliado de los tebanos, y entonces ellos tomaron la Fócida. 


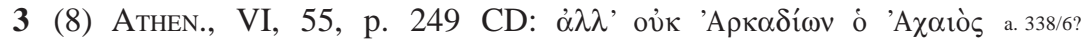

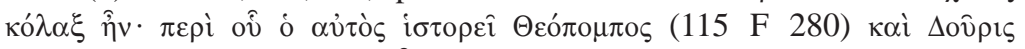

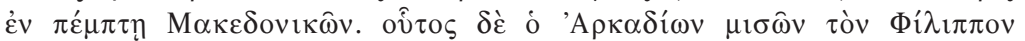

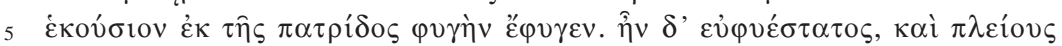

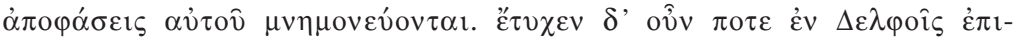

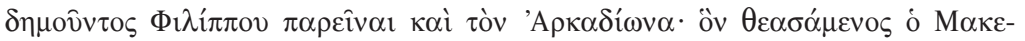

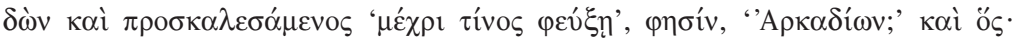

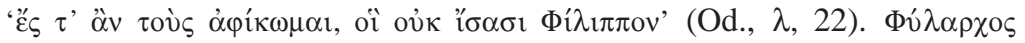

10 ' '

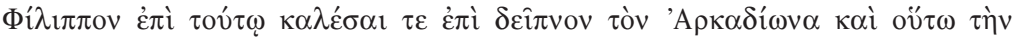
$\ddot{\varepsilon} \chi \theta \rho \alpha v \delta 1 \alpha \lambda \dot{\sigma} \sigma \alpha \sigma \theta \alpha 1$.

\section{$\overline{\mathrm{Z}}$}

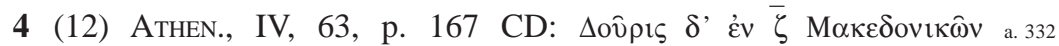

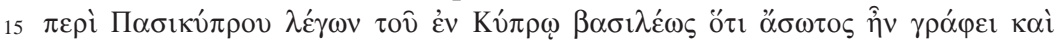

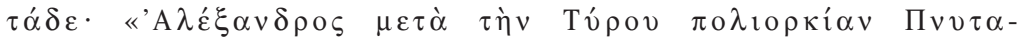

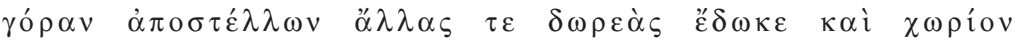

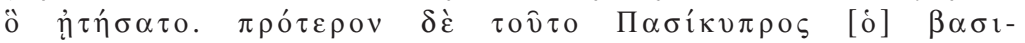

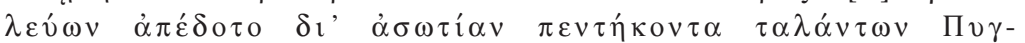

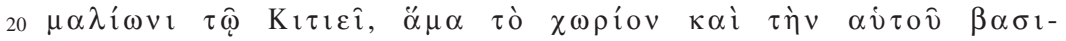

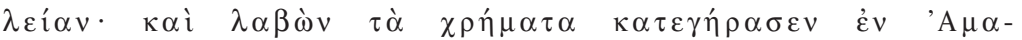

$\theta$ oิvขน.»

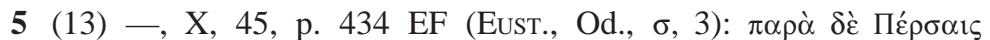

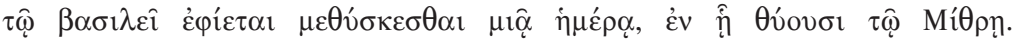

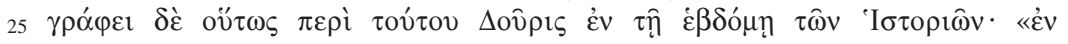

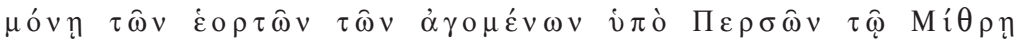

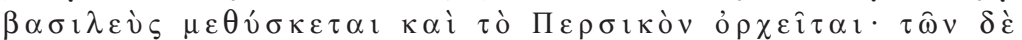

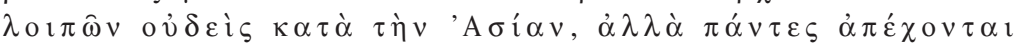

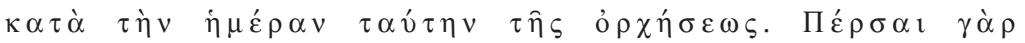

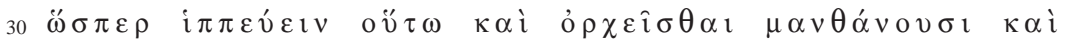

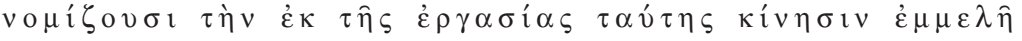

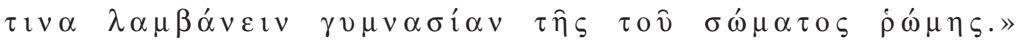

\section{$\overline{\mathrm{H}}$}

356 (16) Schol. Dion. Thrac. [Gr. Gr. III], p. 184, 27 Hilgard:

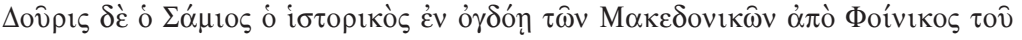

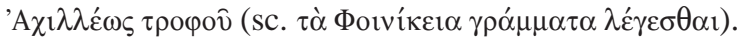

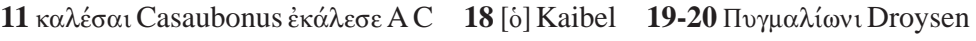

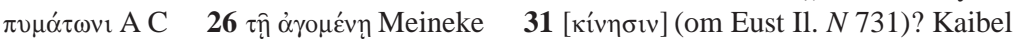


a. 338/6? 3 (8) Ateneo, VI, 55, p. 249 CD: Pero Arcadio el aqueo no era un adulador. Acerca de él habla el mismo Teopompo, y Duris en el libro V de las Historias macedonias. "Este Arcadio, odiando a Filipo, se desterró voluntariamente de su patria. Era muy talentoso y se recuerdan muchas de sus anécdotas: se dio el caso de que una vez, estando Filipo en Delfos, también Arcadio estaba presente; viéndolo el macedonio y dirigiéndose a él, le dijo: '¿hasta cuándo huirás, Arcadio?', y él respondió: 'hasta que llegue con quienes no conocen a Filipo' (Od., XI, 122). Filarco, en el libro vigésimo primero de sus Historias dice que Filipo, riendo ante esta ocurrencia, invitó a Arcadio a una comida. Y así se disolvió la enemistad”.

\section{Libro VII}

a. 3324 (12) Ateneo, IV, 63, p. 167 CD: En el libro VII de las Historias macedonias, Duris, hablando acerca de Pasicipro, rey de Chipre, y diciendo que era pródigo, también escribe lo siguiente: "Después del sitio de Tiro, Alejandro, despidiendo a Pnitágoras, le dio, entre otros regalos, el palacio que él mismo le pidió; antes, a causa de su prodigalidad, el rey Pasicipro se lo había vendido a Pigmalión el citeo, junto con el lugar y su propio reino, por cincuenta talentos"; y dice que tomando el dinero envejeció en Amatunte.

5 (13) - X, 45, p. 434 EF (Eustacio, Comentarios a la Ilíada y la Odisea, XVIII, 3): Entre los persas está permitido que el rey se embriague en un único día, en el que se hacen sacrificios a Mitra. Duris en el libro VII de las Historias macedonias escribe así sobre esto: "Sólo en un día, el de las fiestas celebradas por los persas a Mitra, el rey se embriaga y baila El persa, y ninguno de los demás lo hace durante ese día de la danza. En efecto, los persas aprenden a bailar así como aprenden a cabalgar; y consideran que un movimiento de esa índole es adecuado para hacer ejercicio de fortaleza para el cuerpo".

\section{Libro VIII}

6 (16) Escolios sobre Dionisio Tracio [Gramáticos griegos, III], p. 184, 27 Hilgard: Duris, el historiador samio, en el libro VIII de las Historias macedonias dice que (las letras son llamadas fenicias) por Fénix, el maestro de Aquiles. 


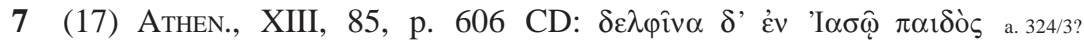

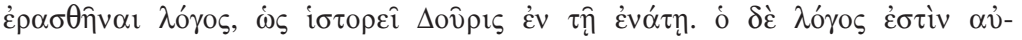

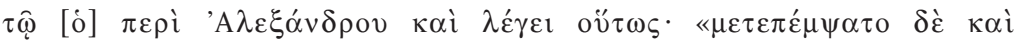

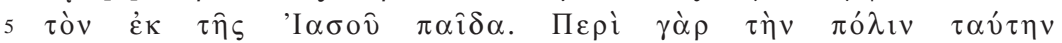

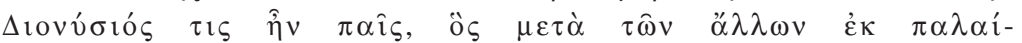

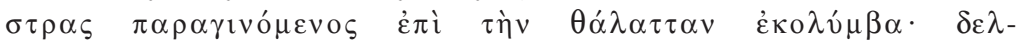

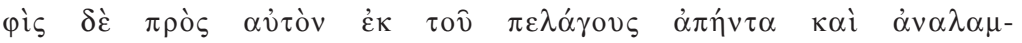

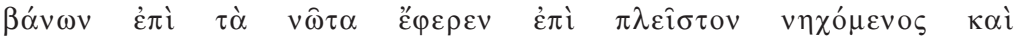

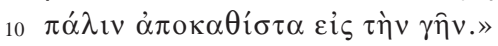

\section{$\overline{\mathrm{I}}$}

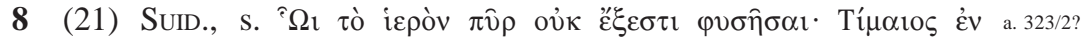

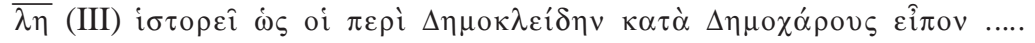

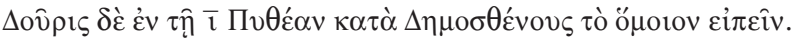

15

\section{$\overline{I E}$}

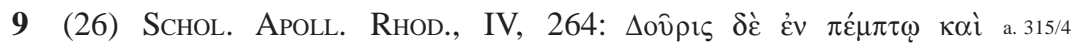

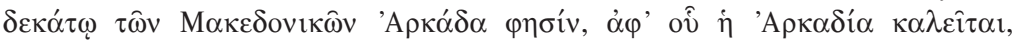

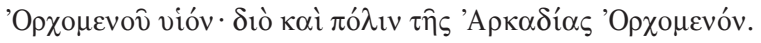

\section{$\overline{\mathrm{IF}}$}

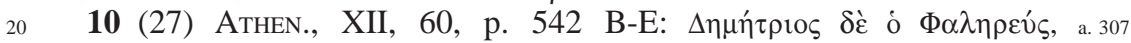

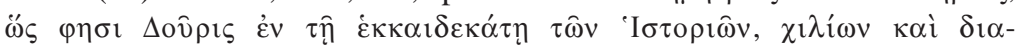

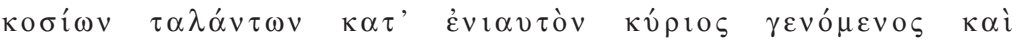

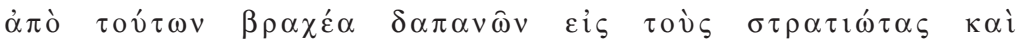

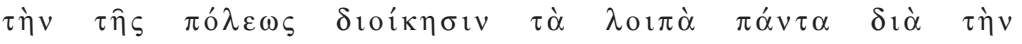

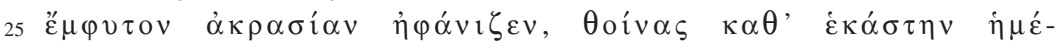

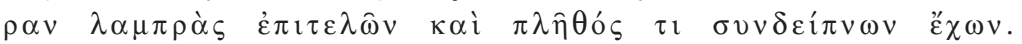

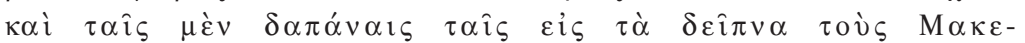

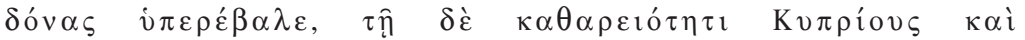

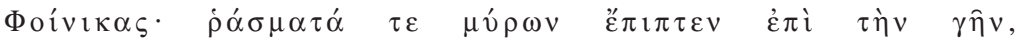

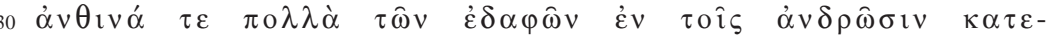

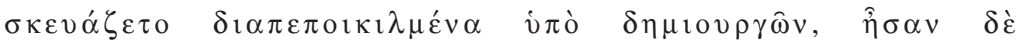

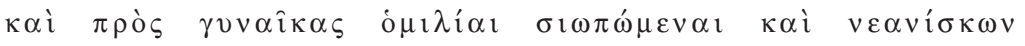

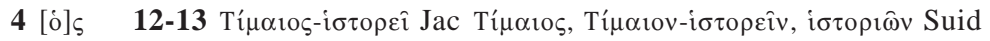

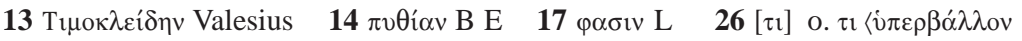

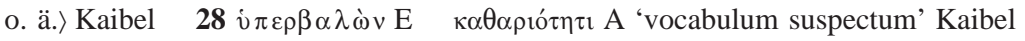

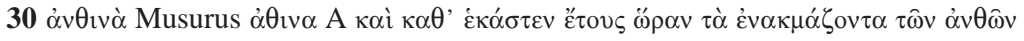

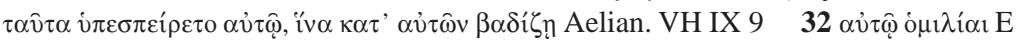

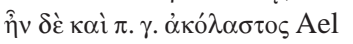


a. 324/3? 7 (17) Ateneo, XIII, 85, p. 606 CD: En Jaso se cuenta que un delfín se enamoró de un niño, como relata Duris en el libro IX, quien habla acerca de Alejandro, y dice así: "mandó llamar también al niño desde Jaso. Pues cerca de esa ciudad había un niño llamado Dionisio que, regresando de la palestra con otros niños, se zambullía en el mar. Y un delfín salía a su encuentro desde el mar y, subiéndolo a sus espaldas, nadando lo llevaba un largo trecho, y de nuevo lo devolvía a la tierra".

\section{Libro X}

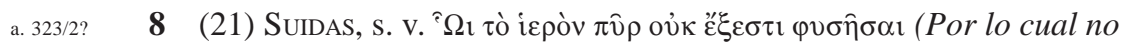
está permitido soplar el fuego sagrado). Timeo en el libro XXXVIII cuenta que los que estaban con Demóclides dijeron eso contra Demócares ... Y Duris en el libro X, que la pitia dijo lo mismo contra Demóstenes.

\section{Libro XV}

a. 315/4 9 (26) Escolios sobre Apolonio de Rodas, IV, 264: Duris en el libro $\mathrm{XV}$ de las Historias macedonias dice que Arcas, a partir del cual toma su nombre Arcadia, era hijo de Orcómenos, y que, por eso, la ciudad orcómena de Arcadia también se llama Orcómenos.

\section{Libro XVI}

a. 30710 (27) Ateneo, XII, 60, p. 542 B-E: Demetrio de Falero, como dice Duris en el libro XVI de las Historias macedonias, adueñándose cada año de mil doscientos talentos y gastando un poco en los soldados y en la administración de la ciudad, derrochaba todo lo demás en su libertinaje natural, celebrando diariamente espléndidos festines y teniendo una gran multitud de convidados. Superaba a los macedonios en gastos de comida, y a los chipriotas y a los fenicios en refinamiento: aspersiones de perfumes caían sobre la tierra, y alfombras floreadas, decoradas por los artesanos, adornaban muchos pisos de los comedores; también, a escondidas, tenían lugar relaciones íntimas con las mujeres y amores nocturnos con los jóvenes; y Demetrio, que establecía leyes para los otros y ordenaba sus 


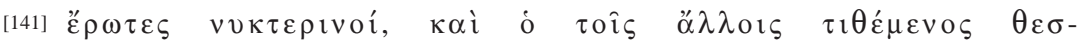

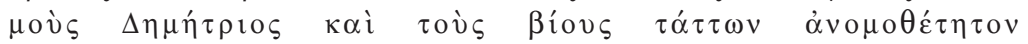

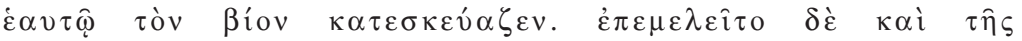

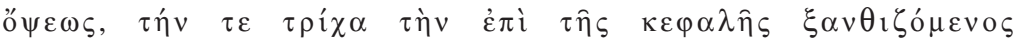

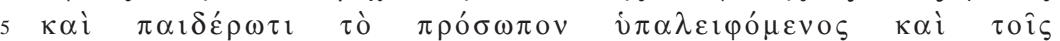

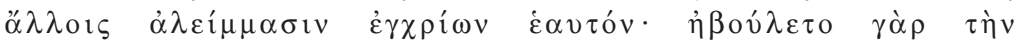

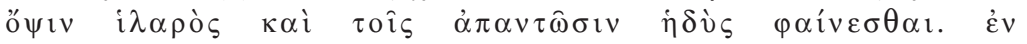

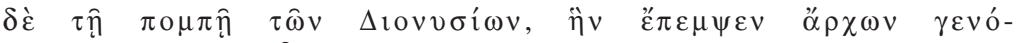

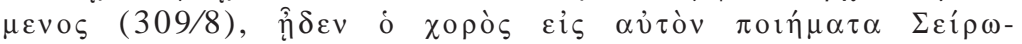

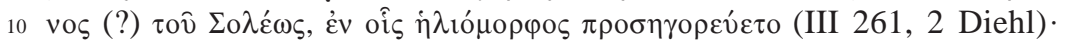

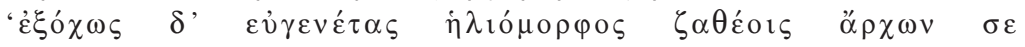
$\tau \imath \mu \alpha \hat{\imath} \sigma \imath \gamma \varepsilon \rho \alpha i ́ \rho \varepsilon$ ’.

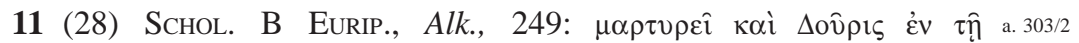

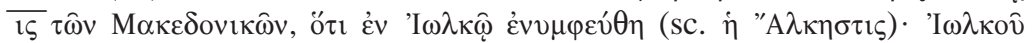

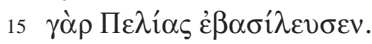

$\overline{\mathrm{IZ}}$

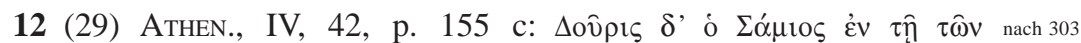

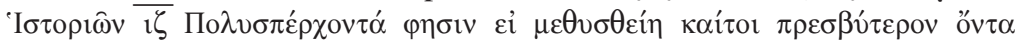

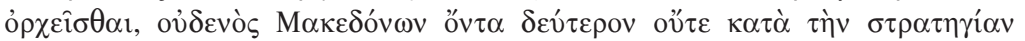

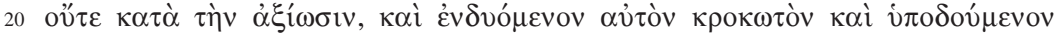

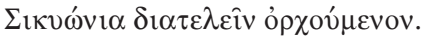

$\overline{\mathrm{KB}}$

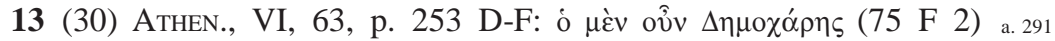

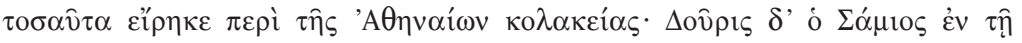

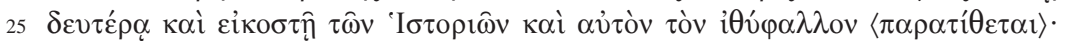

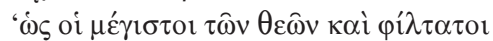

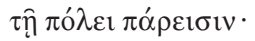
$\dot{\varepsilon} v \tau \alpha \hat{v} \theta \alpha\langle\gamma \grave{\alpha} \rho \Delta \eta \dot{\eta} \mu \eta \tau \alpha \kappa \alpha \grave{i}\rangle \Delta \eta \mu \eta \dot{\tau} \tau \rho ı v$

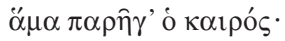

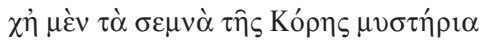

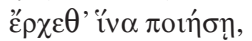

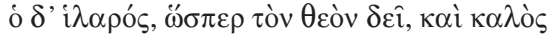

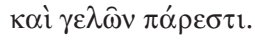

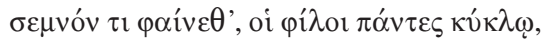

35

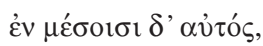

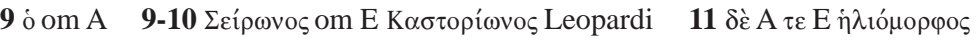

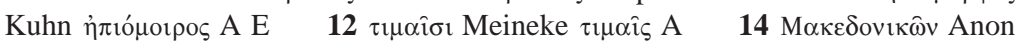

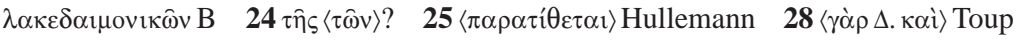

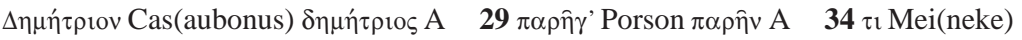

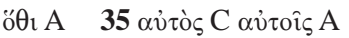


vidas, organizaba la suya sin reglas. Incluso cuidaba su aspecto tiñéndose [141] de rubio los cabellos de la cabeza y frotándose el rostro con cosméticos rojos y ungiéndose con otros perfumes, pues, en cuanto a su aspecto, quería parecer alegre y agradable a todos. Ciertamente en la procesión de las dionisíacas, la cual dirigió cuando era arconte (309/8 a. C.), el coro cantó en su honor unos poemas de Sirón de Solos, en los cuales él era llamado heliomorfo: "El arconte, muy noble de nacimiento, con aspecto de Sol, te honra con honores divinos".

a. 303/2 11 (28) Escolio $B$ sobre EuRíPIDES, Alcestis, 249: También Duris en el libro XVI de las Historias macedonias atestigua que (Alcestis) fue desposada en Yolcos: Pelias fue rey de Yolcos.

\section{Libro XVII}

nach 30312 (29) Ateneo, IV, 42, p. 155 c: Duris de Samos en el libro XVII de las Historias macedonias dice que Polisperconte, si se emborrachaba, bailaba, a pesar de que era anciano, y no era inferior a ninguno de los macedonios ni en el arte militar ni en la dignidad, y que él, vistiendo una túnica amarilla y calzando las sicionias, bailaba constantemente.

\section{Libro XXII}

a. 29113 (30) Ateneo, VI, 63, p. 253 D-F: Pues bien, Demócares ha dicho muchas cosas acerca de la adulación de los atenienses, y en el libro XXII de las Historias macedonias, Duris de Samos incluso <cita> el itifálico:

¡Cómo los más grandes de los dioses y los más amados en la ciudad están presentes!

En efecto, aquí, <a Deméter y> a Demetrio los reunió la suerte: también ella, los impresionantes misterios de Core, vino a celebrar;

él, alegre, como debe ser un dios, y hermoso y riendo, está presente.

Mostráis algo impresionante, todos sus amigos alrededor, él está en medio de ellos: 


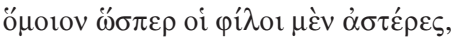

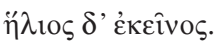

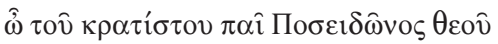

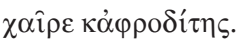

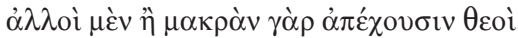

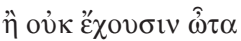

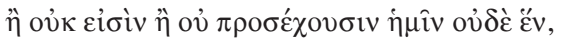

$\sigma \grave{\varepsilon} \delta$ غ̇ $\pi \alpha \rho o ́ v \theta$ ' ó $\rho \hat{\omega} \mu \varepsilon v$,

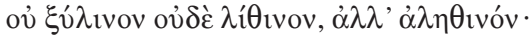

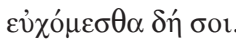

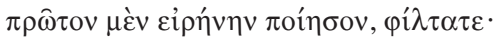

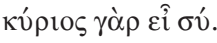

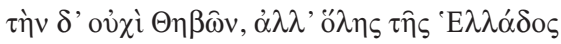

$\Sigma \varphi i ́ \gamma \gamma \alpha \pi \varepsilon \rho \iota \kappa \rho \tau о \hat{\sigma} \sigma \alpha \nu$,

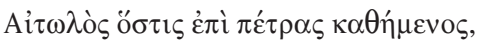

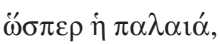

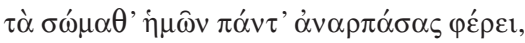

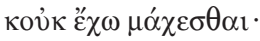

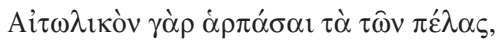

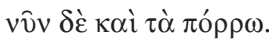

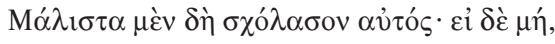

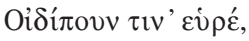

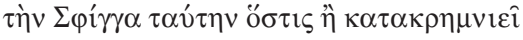

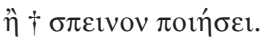

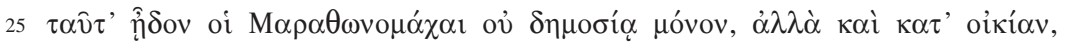

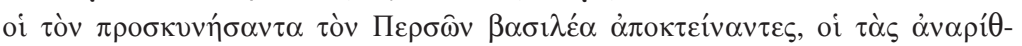

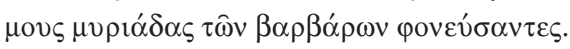

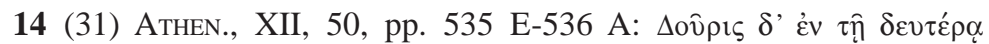

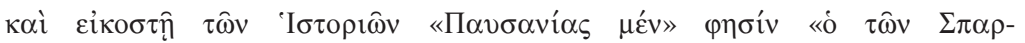

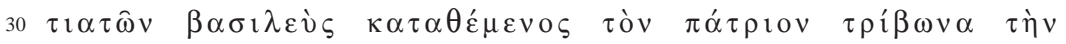

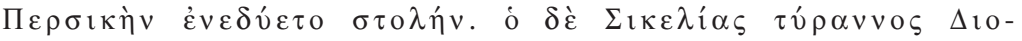

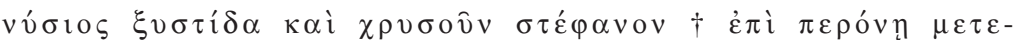

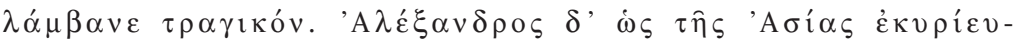

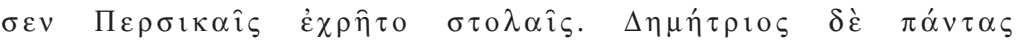

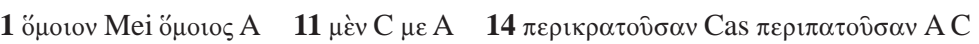

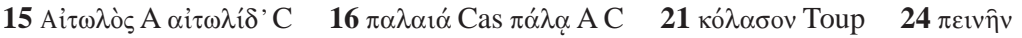

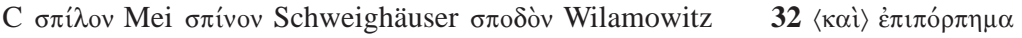

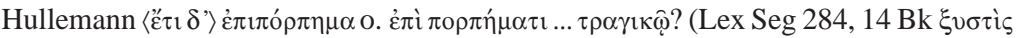

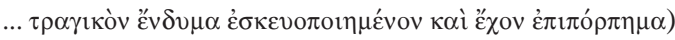


es justamente como si los amigos fueran las estrellas, y él, el Sol.

¡Oh hijo del poderosísimo dios Posidón

y de Afrodita, salve!

Otros dioses, sin duda, o están muy lejos

o no tienen orejas

o no existen o no nos prestan ninguna atención,

mas a ti te vemos presente,

ni de madera ni de piedra, sino de verdad:

Por eso, te rogamos.

En primer lugar, restituye la paz,

queridísimo,

pues tú eres el soberano.

A la esfinge dominante

no sólo de Tebas, sino de Grecia entera

(el etolo que, sentado sobre una roca

como la esfinge de antes,

robándose todas nuestras cosas, se las lleva

y yo no puedo combatir:

es algo etólico robarse las cosas del vecino

pero ahora, incluso las que están lejos),

castígala tú en el más alto grado, y si no,

encuentra a algún Edipo

que a esta esfinge la lance al precipicio

o la convierta en †pinzón.

Los que pelearon en Maratón, esos que mataron al que adoraba al rey de los persas y dieron muerte a miríadas de innumerables bárbaros, cantaban esto no sólo en público, sino también en su casa.

14 (31) Ateneo, XII, 50, pp. 535 E-536 A: En el libro XXII de las Historias macedonias, Duris dice: "Pausanias, el rey de los espartanos, quitándose la capa tradicional, se ponía un vestido persa. Dionisio, el tirano de Sicilia, se ponía una túnica larga y una corona de oro † y además, una capa de actor. Alejandro, cuando se adueñó de Asia, usó vestidos persas. Pero Demetrio superó a todos: el calzado que usaba se lo mandaba a 


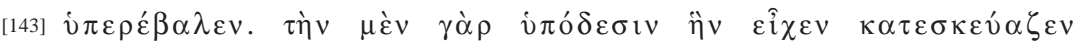

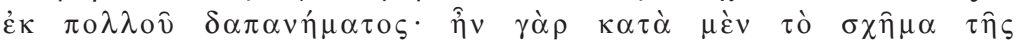

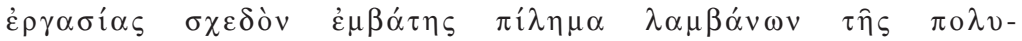

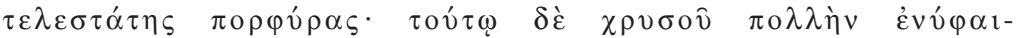

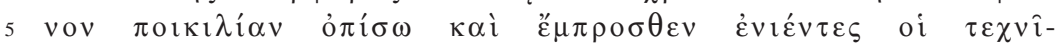

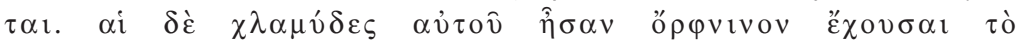

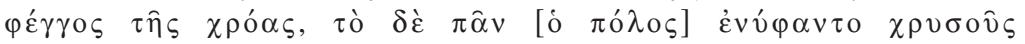

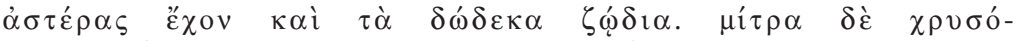

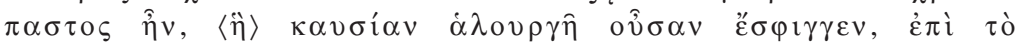

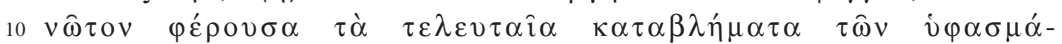

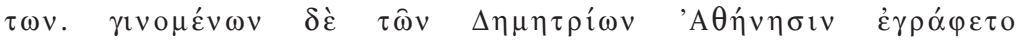

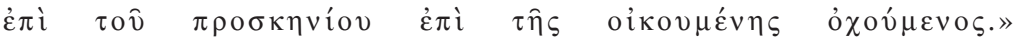

\section{$\mathrm{K} \Gamma$}

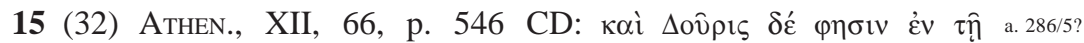

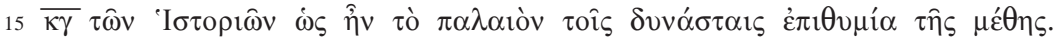

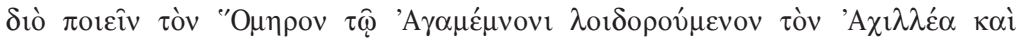

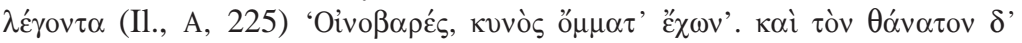

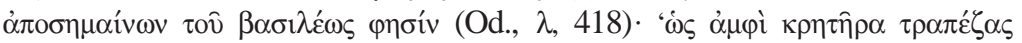

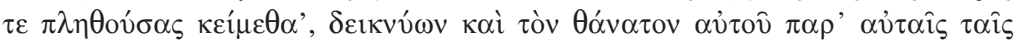

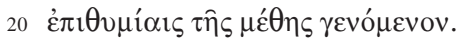

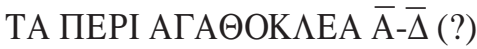

$\overline{\mathrm{B}}$

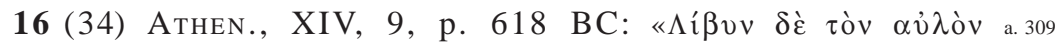

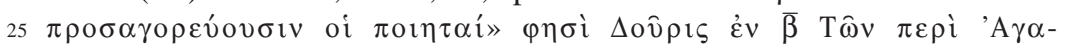

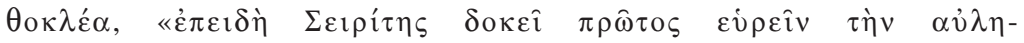

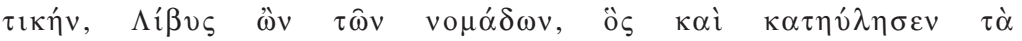
$\mu \eta \tau \rho \hat{\varphi} \alpha \pi \rho \hat{\omega} \tau \mathrm{\sigma} \varsigma . »$

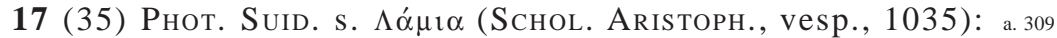

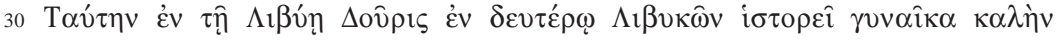

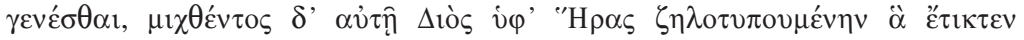

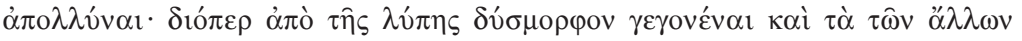
$\pi \alpha \imath \delta^{\prime} \alpha \dot{\alpha} v \alpha \rho \pi \alpha ́ \zeta o v \sigma \alpha v \delta 1 \alpha \varphi \theta \varepsilon i ́ \rho \varepsilon v$.

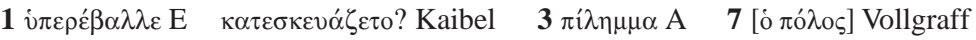

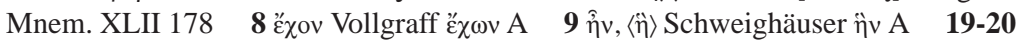

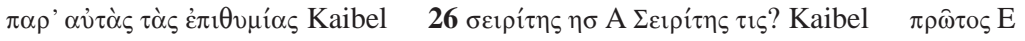

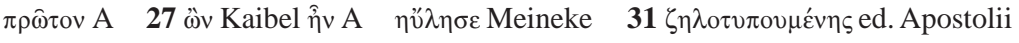
(X 44) Plantiniana Hullemann 
hacer con mucho dinero, pues era, por la forma de su hechura, casi un [143] coturno forrado con tela de púrpura costosísima; los artesanos bordaban, por delante y por detrás, una policromía abundante en oro. Sus clámides, que tenían la claridad de su piel, eran pajizas, y en ellas bordaron el universo con estrellas doradas y los doce signos del zodíaco. Su diadema estaba bordada en oro; ésta ceñía un sombrero que era de púrpura, y dejaba caer hasta la espalda las últimas franjas de velos. Cuando se celebraron en Atenas las fiestas de Demetrio, éste fue pintado en el proscenio, cabalgando sobre el mundo habitado".

\section{Libro XXIII}

a. 286/5? 15 (32) Ateneo, XII, 66, p. 546 CD: Y Duris dice en el libro XXIII de las Historias macedonias que, antiguamente, los gobernantes tenían pasión por la bebida; que, por eso, Homero escribe que Aquiles insulta a Agamenón y le dice "borracho, con ojos de perro" (Il., I, 225), y, describiendo la muerte del rey, dice: "icómo en torno de la crátera y de las mesas llenas yacíamos!" (Od., XI, 418), mostrando que también su muerte sucedió justamente entre sus pasiones por la bebida.

(F 56-59)

EN TORNo a AGATOCLES, Libros I-IV (?)

\section{Libro II}

a. 30916 (34) Ateneo, XIV, 9, p. 618 BC: Duris dice en el libro II de En torno a Agatocles: "Los poetas llaman libia a la flauta, porque parece que Sirites fue el primero en encontrar el arte relativo a la flauta: él era un pastor libio, el cual también fue el primero que acompañó con la flauta los ritos de Cibeles".

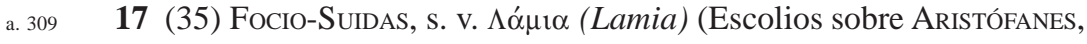
Aves, 1035): En el libro II de las Historias libias, Duris cuenta que ella fue una hermosa mujer en Libia, y que, después de que Zeus se unió con ella, envidiada por Hera, ésta destruyó lo que aquella había parido; que por eso, a partir de esa pena, se puso fea, y, robándose los niñitos de otros, los mata. 


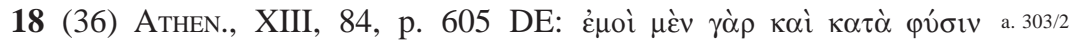

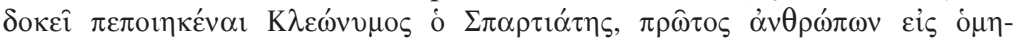

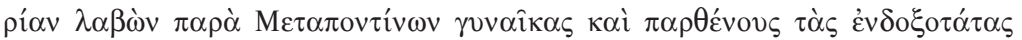

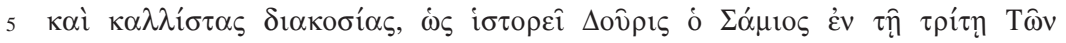

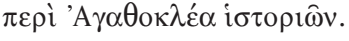

\section{$\bar{\Delta}$}

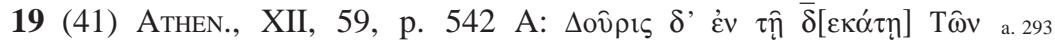

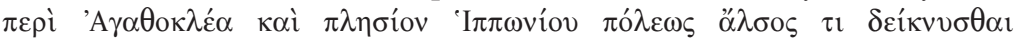

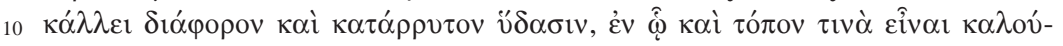

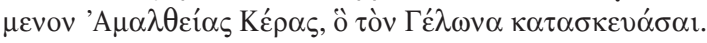

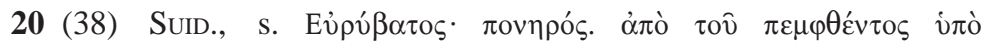

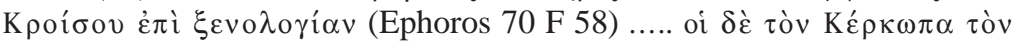

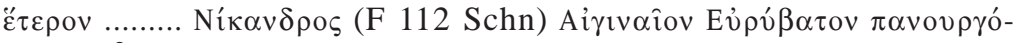

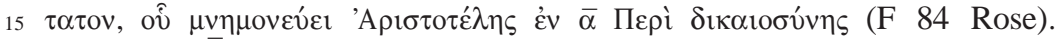

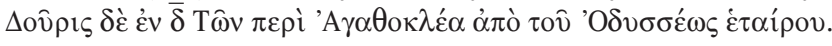

\section{OHNE BuCHZAHL}

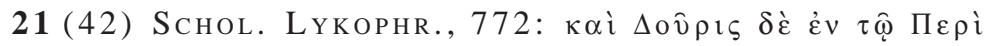

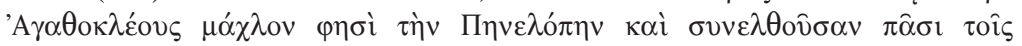

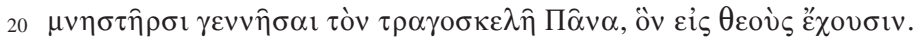

(s. F 60-71. 45?)

\section{$\Sigma \mathrm{AMI} \Omega \mathrm{N} \Omega \mathrm{POI}$}

\section{$\overline{\mathrm{B}}$}

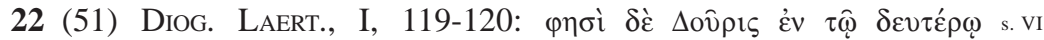

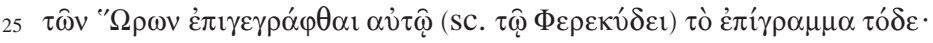

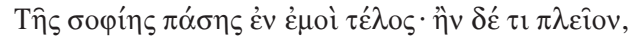

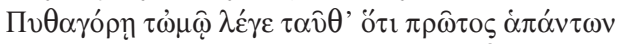

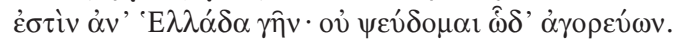

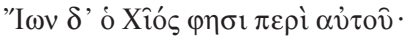

30

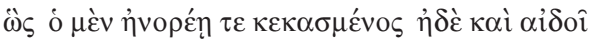

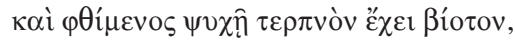

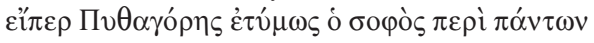

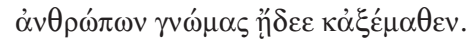

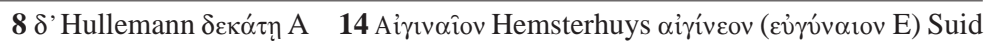

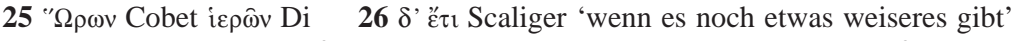

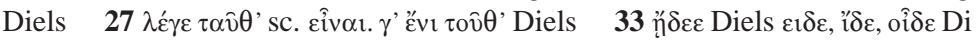


a. 303/2 18 (36) Ateneo, XIII, 84, p. 605 DE: Pues me parece que actuó de acuerdo con la naturaleza "Cleónimo el espartano, el primero de los hombres que, tomando como fianza de los metapontinos a doscientas señoras y vírgenes, las más ilustres y hermosas", como narra Duris de Samos en el libro III de En torno a Agatocles.

\section{Libro IV}

a. 29319 (41) Ateneo, XII, 59, p. 542 A: En el IV libro de En torno a Agatocles, Duris dice que cerca de la ciudad de Hiponio hay un bosque, único por su belleza, y muy bien regado con agua, en el cual también hay un lugar llamado Cuerno de Amaltea, y que éste fue arreglado por Gelón.

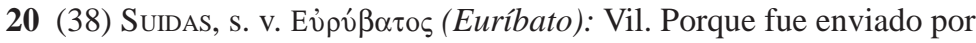
Creso para el reclutamiento de extranjeros ... Otros dicen que era uno de los dos Cércopes ... Nicandro habla del malvadísimo Euríbato egineta, al cual menciona Aristóteles en el libro I de Sobre la justicia. En el libro IV de En torno a Agatocles, Duris lo menciona como compañero de Odiseo.

\section{SIN NÚMERO DE LIBRO}

21 (42) Escolios sobre Licofrón, 772: En su obra En torno a Agatocles, también Duris dice que Penélope era una lasciva y que, habiéndose unido con todos sus pretendientes, dio a luz a Pan, el de patas de chivo, al cual se cuenta entre los dioses.

(s. F 60-71. 45?)

\section{LOS ANALES DE SAMOS}

\section{II}

22 (51) Diógenes Laercio, I, 119-120: En el libro II de Los anales de Samos, Duris dice que (a Ferécides) le está dedicado este epigrama: "En mí yace la cumbre de toda sabiduría; si hay algo más, díselo a mi Pitágoras: él es primero de todos en la tierra griega. No miento hablando asî".

Ión de Quíos dice acerca de Ferécides:

"Éste, así como se adornó con valentía y también con pudor, del mismo modo, muerto, tiene una vida feliz con su alma, si es que Pitágoras, el más sabio de todos, verdaderamente sabía y aprendió las cosas de los hombres". 


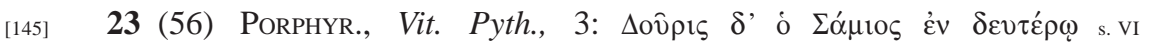

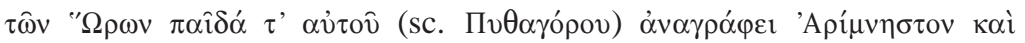

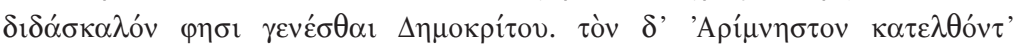

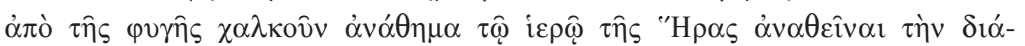

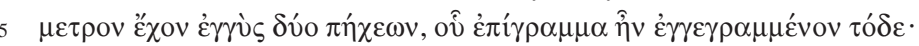

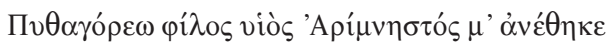

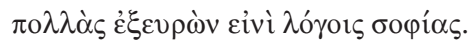

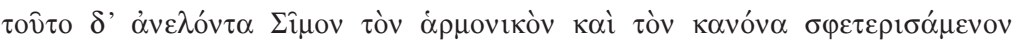

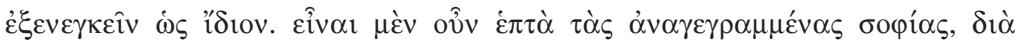

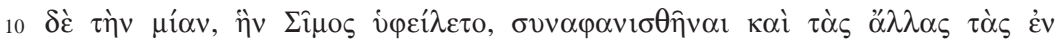

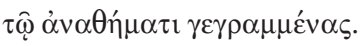

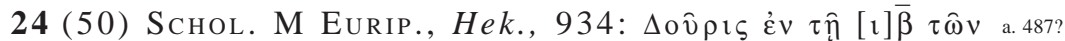

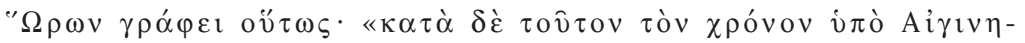

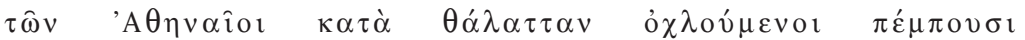

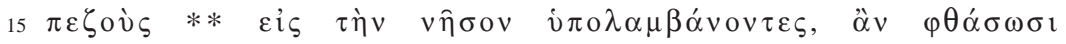

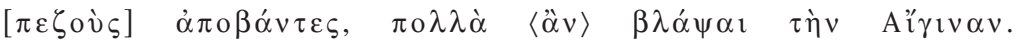

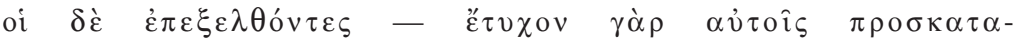

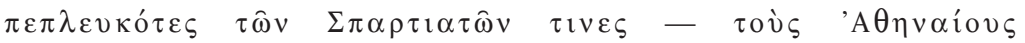

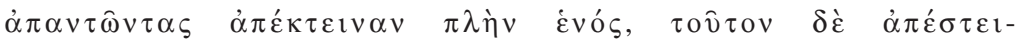

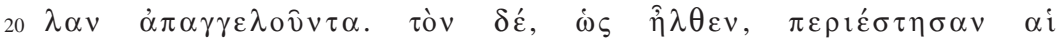

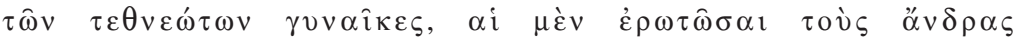

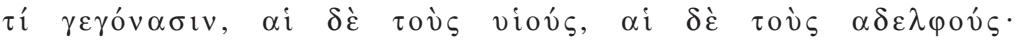

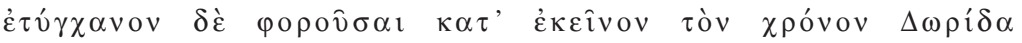

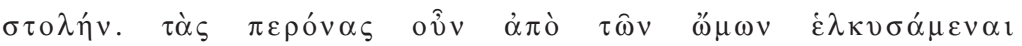

$25 \tau \grave{o} v \quad \ddot{\alpha} v \theta \rho \omega \pi \mathrm{ov} \quad \pi \rho \hat{\omega} \tau \mathrm{ov} \quad \dot{\varepsilon} \xi \varepsilon \tau \hat{\varphi} \varphi \lambda \omega \sigma \alpha \nu, \quad \varepsilon \hat{\imath} \tau \alpha \quad \dot{\alpha} \pi \dot{\varepsilon} \kappa \tau \varepsilon \imath \nu \alpha \nu$.

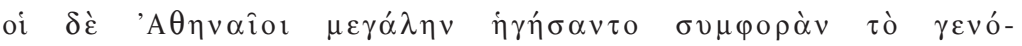

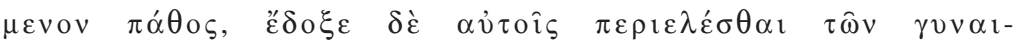

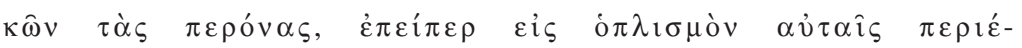

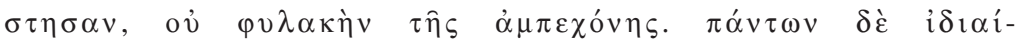

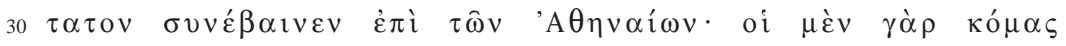

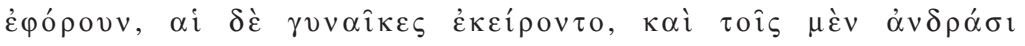

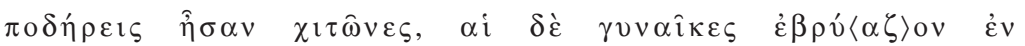

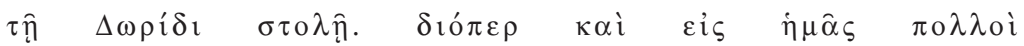

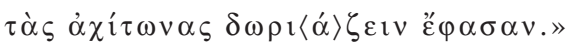

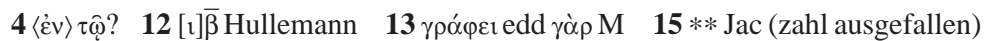

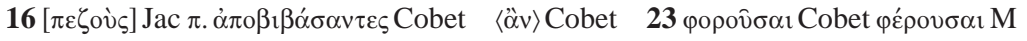

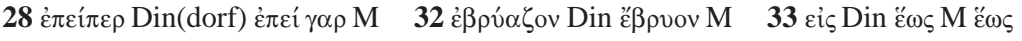

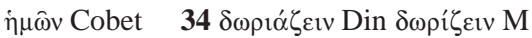


s. vi 23 (56) Porfirio, Vida de Pitágoras, 3: En el libro II de Los anales de [145] Samos, Duris de Samos escribe que Arimnesto fue hijo suyo (de Pitágoras), y dice que fue maestro de Demócrito; que Arimnesto, volviendo del destierro, erigió un exvoto de bronce en el santuario de Hera, el cual tenía un diámetro de casi dos codos, donde estaba inscrito este epigrama:

Arimnesto, el amado hijo de Pitágoras, me erigió por haber encontrado mucha sabiduría en sus palabras

y dice que el músico Simo, quitando éste y apropiándose de la teoría del monocordio, la publicó como propia. En efecto, dice que eran siete las sabidurías que estaban inscritas, y que a causa de ésa única que sustrajo Simo, desaparecieron también las otras que estaban escritas en el exvoto.

a. 487? 24 (50) Escolio $M$ sobre EuRírides, Hécuba, 934: En el (X)II libro de Los anales de Samos, Duris escribe así: "En ese tiempo, los atenienses, a quienes los eginetas hostigaban por mar, enviaron ** a unos soldados de infantería a la isla, suponiendo que, si desembarcaban antes, dañarían mucho a Egina. Pero éstos, enfrentándolos — por casualidad algunos espartanos navegaron hacia ese lugar contra aquéllos- mataron a los atenienses que iban a su encuentro, excepto a uno, al cual enviaron para que llevara la noticia. Y a éste, cuando llegó, lo rodearon las mujeres de los muertos, unas preguntando qué les había sucedido a sus maridos; otras, a sus hijos, y otras, a sus hermanos. Casualmente, en esa ocasión, ellas llevaban manto dorio. Así pues, quitándose los broches de sus hombros, primero cegaron al hombre; luego, lo mataron. Los atenienses pensaron que el incidente ocurrido había sido una gran desgracia, y les pareció bien quitar los broches de las mujeres, precisamente porque, para ellas, se habían convertido en armas y no en guardianes de su vestido. Entre los atenienses sucedió lo más curioso de todo; en efecto, ellos llevaban melenas, y las mujeres se rapaban; los hombres usaban túnicas hasta los pies, y las mujeres se regodeaban en su manto dorio. Por eso, incluso en nuestros tiempos, muchos dicen que las que no llevan túnica imitan a las dorias". 


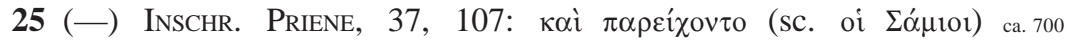

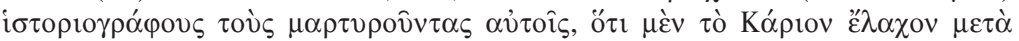

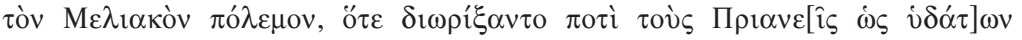

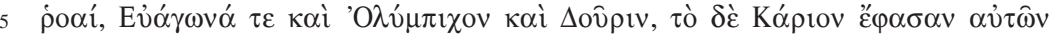

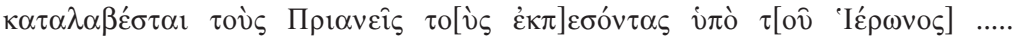

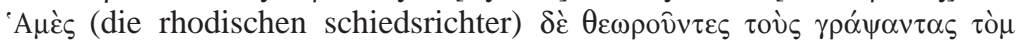

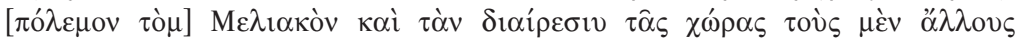

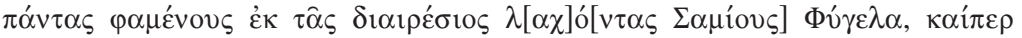

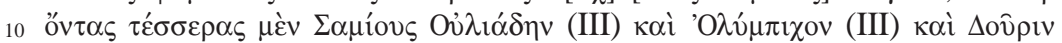

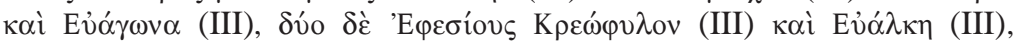

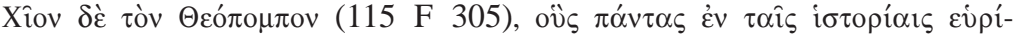

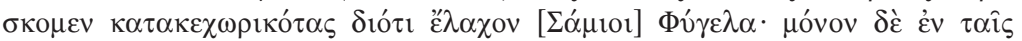

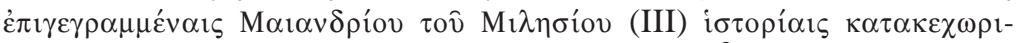

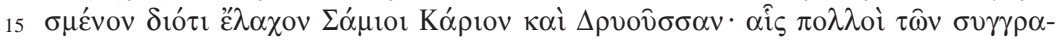

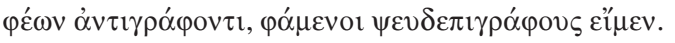

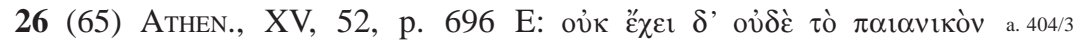

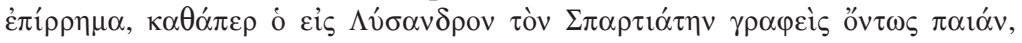

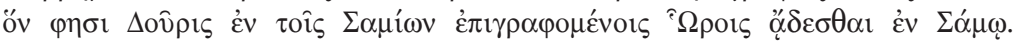
20 s. F 71.

(F 79-81?)

\section{ПЕPI NOM $\Omega N \bar{A}(?)$}

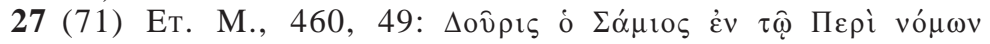

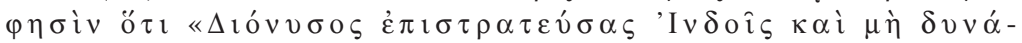

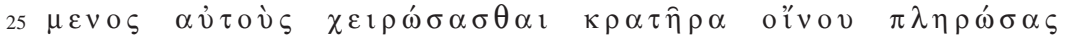

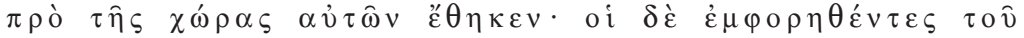

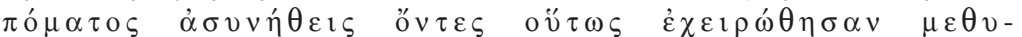

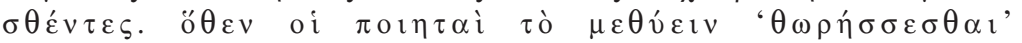

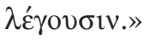

\section{ПЕРІ ТРАГ $\Omega \mathrm{I} \triangle \mathrm{IA} \Sigma \overline{\mathrm{A}}(?)$}

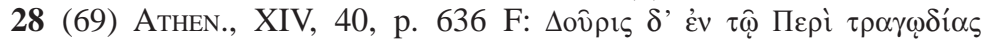

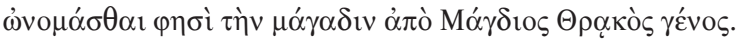

\section{ПЕРI ЕYРІПI $\triangle$ OY KAI $\Sigma$ OФOK $\Lambda$ EOY $\Sigma \overline{\mathrm{A}}(?)$}

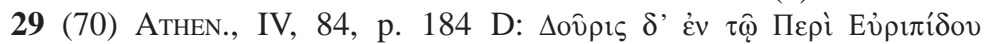

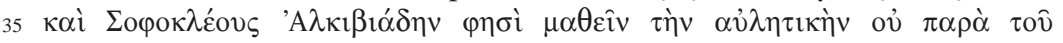

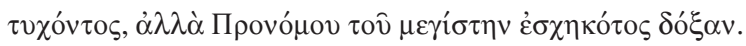

$36\langle\pi \alpha \rho \grave{\alpha}\rangle$ Проvónov? 
ca. 70025 (-) InsCRIPCIÓN DE PrIeNe, 37, 107: Y (los samios) citaban a los historiadores Eugonas, Olímpico y Duris; éstos atestiguaban a su favor, por una parte, que ellos habían obtenido el Cario después de la guerra melíaca, cuando establecieron su límite con los prieneos, como lo establecen las corrientes de agua; por la otra, afirmaban que su Cario había sido ocupado por los prieneos, que fueron expulsados por Hierón... Nosotros (los árbitros rodios), examinando a los que describieron la guerra melíaca y el reparto de la región, vemos que todos los otros afirman que, a partir del reparto, los samios obtuvieron Figuela, a pesar de que, de los que lo afirman, cuatro son samios —Ulíades y Olímpico, Duris y Eugonas-; dos son efesios -Creófilo y Eualco-, y uno de Quíos - Teopompo-; y encontramos que todos ellos, en sus historias, registran que los samios obtuvieron Figuela. Únicamente en las historias atribuidas a Meandro de Mileto se registra que los samios obtuvieron el Cario y Drusa. Muchos de los historiadores escriben en contra de estas historias, diciendo que son falsas.

a. 404/3 26 (65) Ateneo, XV, 52, p. 696 E: No tiene la exclamación relativa al peán, como sí la tiene el poema — un verdadero peán— dedicado a Lisandro el espartano; Duris en Los anales de Samos afirma que este poema se cantaba en Samos. fr. 71.

$$
\text { EN TORNO A LAS LEYES, I (?) }
$$

27 (71) Etymologicum magnum, 460, 49: En su libro En torno a las leyes, Duris de Samos dice que Dioniso, haciendo una expedición contra los indios y no pudiendo someterlos, llenó una crátera de vino y la colocó frente a su país. Ellos, que no estaban habituados a la bebida, sirviéndose del recipiente, se emborracharon y, así, fueron sometidos. Desde entonces, por "estar borracho", los poetas usan "estar bien armado".

EN TORNO A LAS TRAGEDIAS, I (?)

28 (69) Ateneo, XIV, 40, p. 636 F: En su libro En torno a las tragedias, Duris dice que el arpa magadis se llama así a partir de Magdis, de origen tracio.

ACERCA DE EURÍPIDES Y SÓFOCLES, I (?)

29 (70) Ateneo, IV, 84, p. 184 D: En Acerca de Eurípides y Sófocles, Duris dice que Alcibíades no aprendió a tocar la flauta con un cualquiera, sino con Prónomo, que tenía la máxima fama. 


\section{ПРОВ $\Lambda$ HМАТА OMHРIKA}

(s. F 88? 92? 89-91)

\section{$\overline{\mathrm{A}}$}

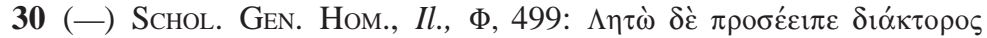

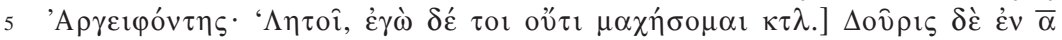

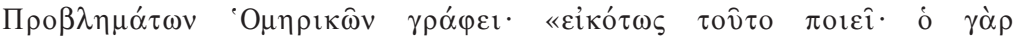

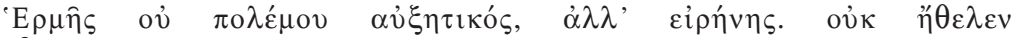

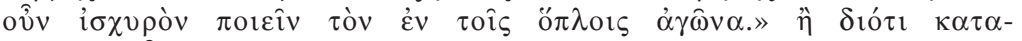

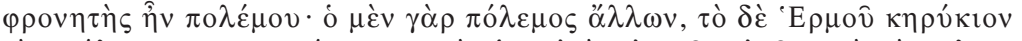

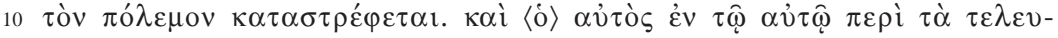
$\tau \alpha \hat{\imath} \alpha * * *$

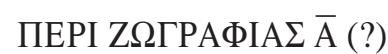

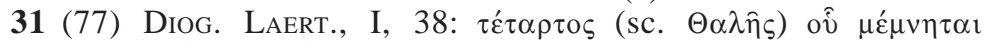

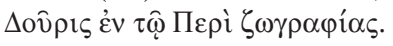

15

(s. T 12 d)

\section{ПЕPI TOPEYTIKH $\Sigma$}

32 (79) Puin., NH, XXXIV, 61: Lysippum Sicyonium Duris negat ullius fuisse discipulum, sed primo aerarium fabrum audendi rationem cepisse pictoris Eupompi responso. eum enim interrogatum, quem se-

20 queretur autecedentium, dixisse monstrata hominum multitudine naturam ipsam imitandam esse, non artificem.

\section{(s. F 82)}

\section{ПЕРІ АГ $\Omega N \Omega N \bar{A}(?)$}

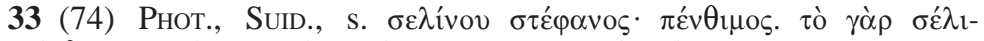

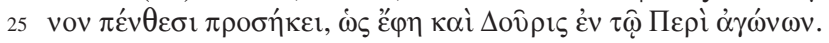

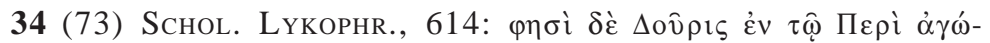

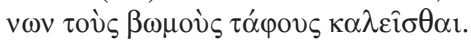

\section{Fragmente ohne Buchtitel.}

AUS DEN ILTOPIAI (F 1-15)

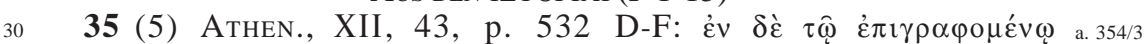

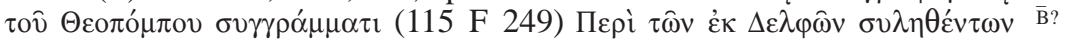

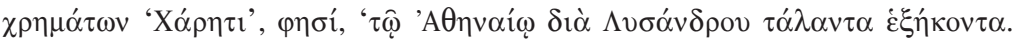

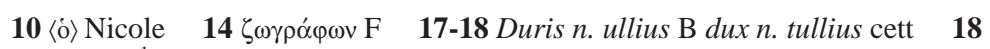
fabrum om $\mathrm{B}^{1} 19$ cepisse-responso $\mathrm{B}$ coepisse picturis itupompi (euponpi $\mathrm{V}$ )

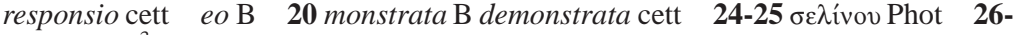

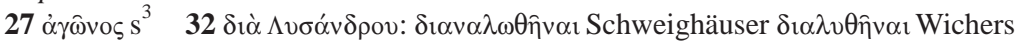




\section{Libro I}

30 (-) Escolio Genavense sobre Homero, Ilíada, XXI, 499: y el mensajero Argifontes, le dice a Leto: “iLeto, yo no voy a pelear contigo”, etcétera] En el libro I de Problemas homéricos, Duris escribe: "hace esto adecuadamente, pues Hermes no favorece la guerra, sino la paz. En efecto, no quería intensificar la pelea con las armas". O porque despreciaba la guerra: la guerra les pertenece a otros, y a Hermes (le pertenece) el caduceo para disolver la guerra. Y el mismo, en el mismo (libro) acerca de lo último ...***

\section{ACERCA DE LAS PINTURAS I (?)}

31 (77) Diógenes Laercio, I, 38: El cuarto Tales, de quien Duris hace mención en su libro Acerca de las pinturas.

\section{(s. T 12 d)}

\section{ACERCA DE LA ESTATUARIA}

32 (79) PlinIo, Historia natural, XXXIV, 61: Duris niega que Lisipo de Sición haya sido alumno de alguien, pero dice que fue un artesano metalúrgico y que se atrevió con la inmediata respuesta del pintor Eupompo, cuando le respondió en seguida, que cuando a él le preguntaron, a quién seguía de los antepasados, dijo, tras enumerar una gran cantidad de hombres, que había que imitar a la naturaleza misma, no a un artista.

\section{(s. F 82)}

\section{ACERCA DE LAS COMPETENCIAS I (?)}

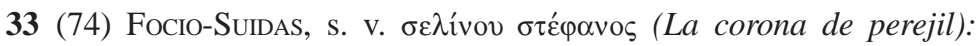
Triste. En efecto, el perejil corresponde a las tristezas, como también dijo Duris en su libro Acerca de las competencias.

34 (73) Escolios sobre Licofrón, 614: En su libro Acerca de las competencias, Duris dice que los altares se llaman tumbas.

\section{Fragmentos sin título de obra}

\section{DE LAS Historias}

a. $354 / 335$ (5) Ateneo, XII, 43, p. 532 D-F: En la obra de Teopompo titulada B? Acerca del dinero saqueado en Delfos, dice "a través de Lisandro, se le dieron sesenta talentos a Cares de Atenas. Con ellos les dio de comer a 


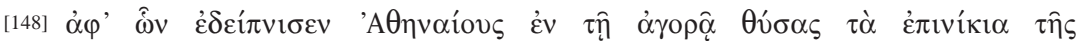

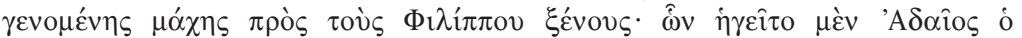

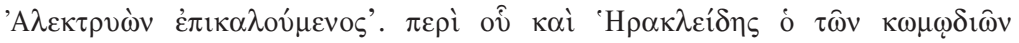

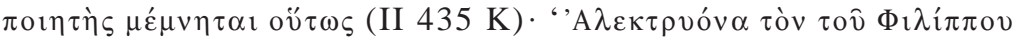

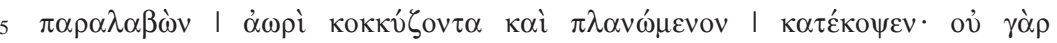

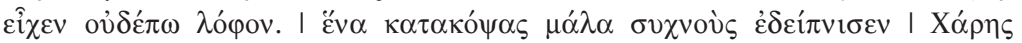

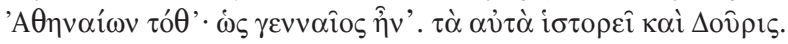

36 (一) Didymos zu Demosth. [Berl. Klass.-T I], 12, 50: ó $\delta \dot{\varepsilon}$ a. 353

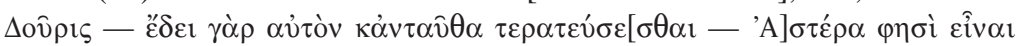

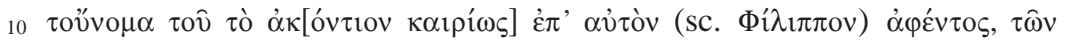

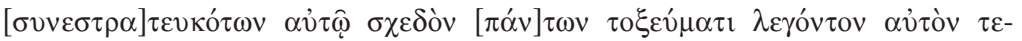

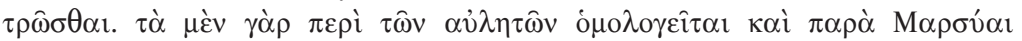

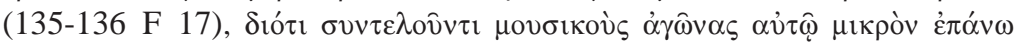

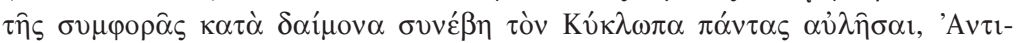

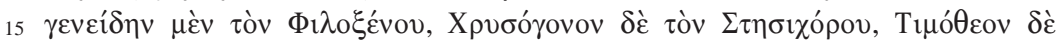

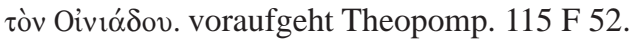

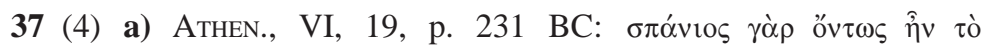

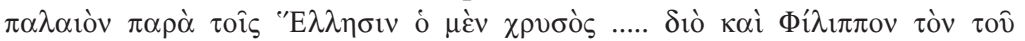

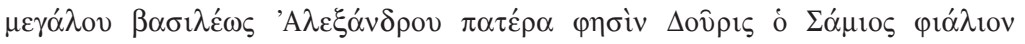

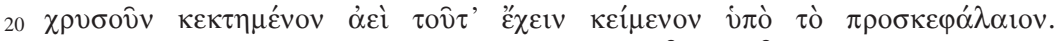

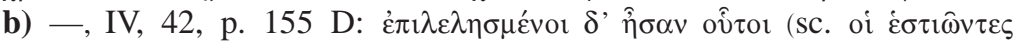

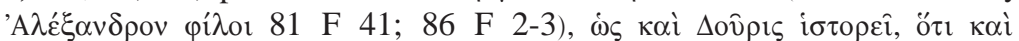

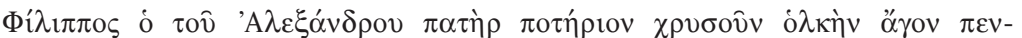

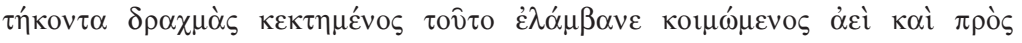

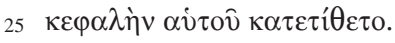

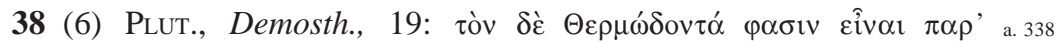

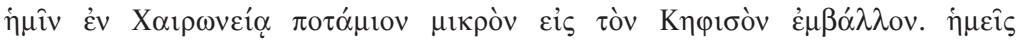

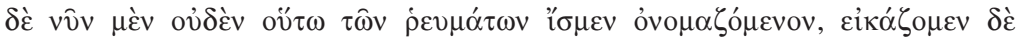

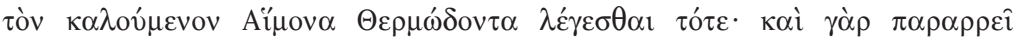

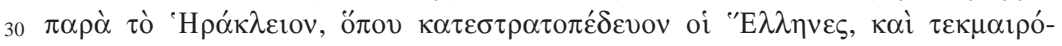

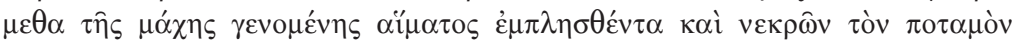

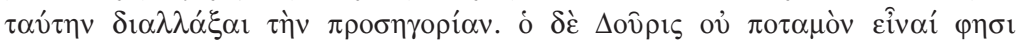

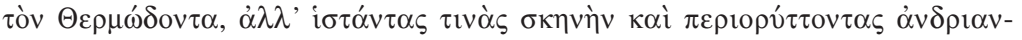

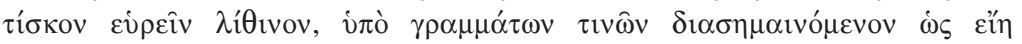

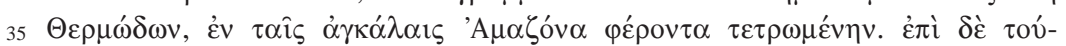

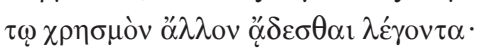

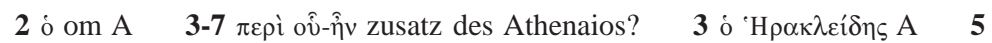

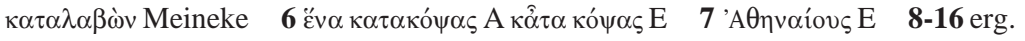

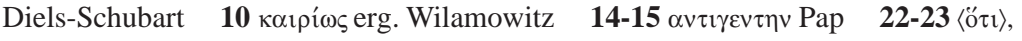

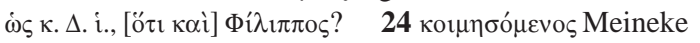


los atenienses que, en el ágora, estaban celebrando con sacrificios su vic- [148] toria en la batalla librada contra los mercenarios de Filipo. A éstos los comandaba Adeo, el apodado Gallo". Sobre éste, también el comediógrafo Heráclides hace mención de la siguiente manera:

Tomando al "gallo" de Filipo puesto que cacareaba a destiempo y andaba suelto, lo mató: todavía no tenía cresta.

Matando a uno, Cares alimentó entonces a una gran multitud de atenienses ¡Cúan generoso era! Esto mismo lo cuenta Duris. -que necesariamente también aquí exagera- dice que Áster era el nombre del que arrojó muy atinadamente la lanza contra él (contra Filipo), mientras casi todos los que guerreaban con éste dicen que fue herido por una flecha. Hablando de flautistas, también se lee lo mismo en Marsias; a saber, que asistiendo Filipo a unas competencias musicales, poco antes de su desgracia, aconteció que, como por presagio, todos los flautistas ejecutaron la obra titulada El cíclope: el flautista Antigeneides ejecutó El cíclope de Filoxeno; Crisógono, el de Estesícoro; Timoteo, el de Eniado ...

37 (4) a) Ateneo, VI, 19, p. 231 BC: Pues realmente, en la antigüedad, el oro era escaso entre los griegos ... Por eso, también Duris de Samos dice que Filipo, el padre del rey Alejandro Magno, siempre tenía bajo su almohada una copita de oro que él había adquirido. b) -, IV, 42, p. 155 D: Ellos (los amigos que hospedaron a Alejandro) olvidaron, como también Duris cuenta, que también Filipo, el padre de Alejandro, adquiriendo una copa de oro que tenía el peso de cincuenta dracmas, la tomaba siempre al acostarse y la colocaba bajo su cabeza.

a. 33838 (6) Plutarco, Demóstenes, 19: Dicen que el Termodonte se halla entre nosotros, en Queronea, y que es un pequeño riachuelo que desemboca en el Cefiso. Ahora nosotros no sabemos nada de una corriente que se llame así, pero conjeturamos que el llamado Hemón, en otros tiempos se llamaba Termodonte; éste, en efecto, fluye junto al templo de Heracles, donde los griegos pusieron su campamento; y suponemos que, transcurrida la batalla, habiéndose llenado de sangre y muertos, el río cambió su nombre. Duris dice que el Termodonte no era un río, sino que levantando algunos una tienda y cavando alrededor, encontraron una estatuita de piedra que, mediante algunas letras, especificaba que era Termodonte, que llevaba en brazos a una amazona herida. Dice que sobre esto se cantaba otro oráculo que decía: 


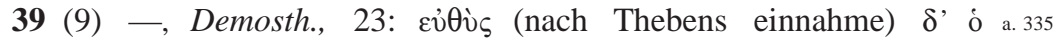

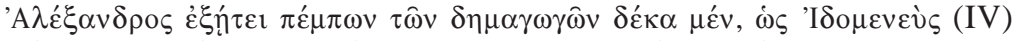

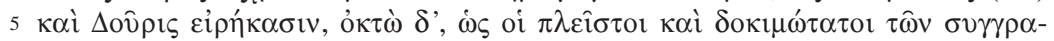

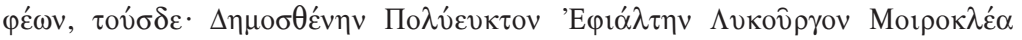

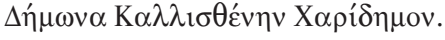

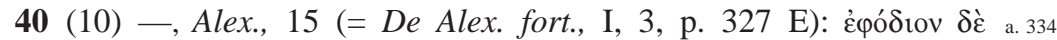

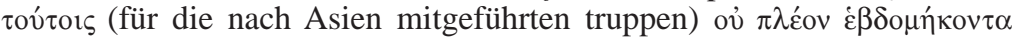

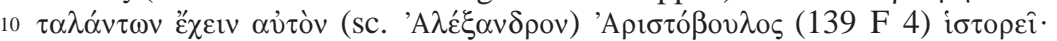

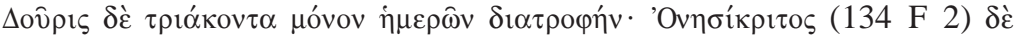

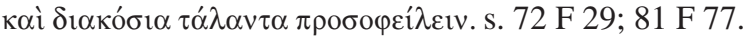

41 (11) a) Clem. Alex., Strom., I, 139, 4, p. 86, 21 Stä: ஸ́s a. 334

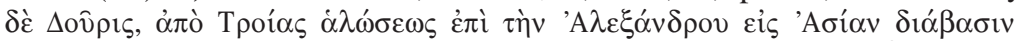

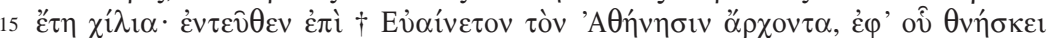

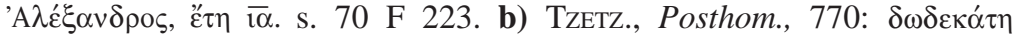

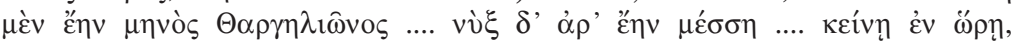

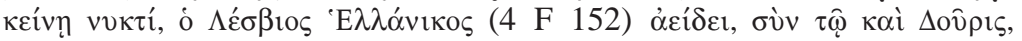

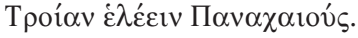

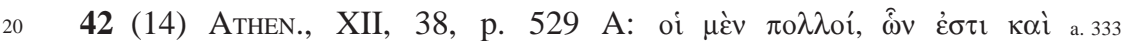

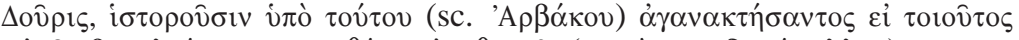

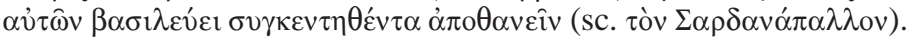

43 (15) Plin., NH, XXXVI, 79: qui de iis (sc. de pyramidibus) a. 332/1 scripserint - sunt Herodotus, Euhemerus (63 F 10), Duris Samius ..... 25 s. 63 F 10.

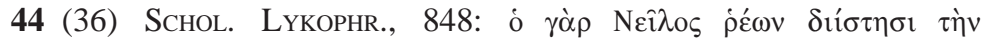

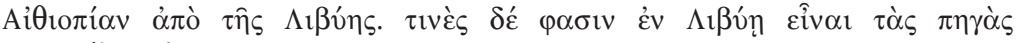

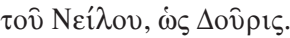

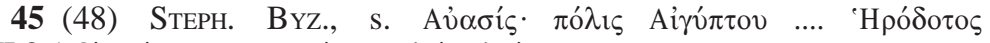

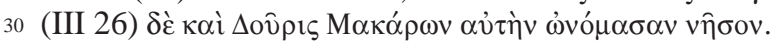

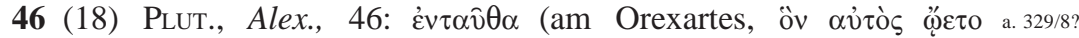

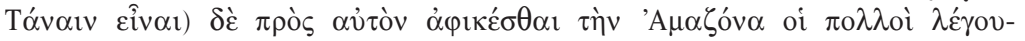

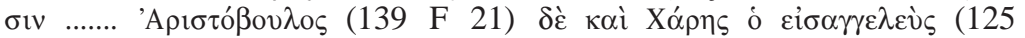

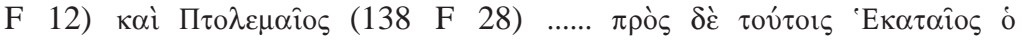

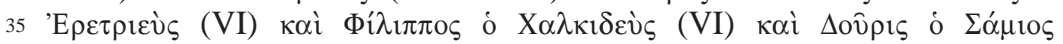

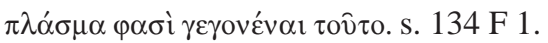

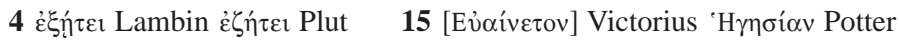
27

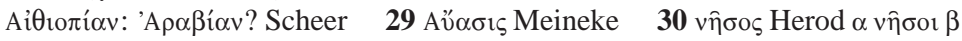


Ave completamente negra, espera la batalla de Termodonte, allí habrá mucha carne humana.

a. 33539 (9) - , - 23: Inmediatamente (después de la toma de Tebas) Alejandro, enviando mensajeros, exigió que le entregaran a diez de sus dirigentes, según dicen Idomeneo y Duris; o a ocho, según dice la mayoría y los más confiables de los autores. Ésta es la lista: Demóstenes, Polieucto, Efialtes, Licurgo, Merocles, Damón, Calístenes y Caridemo.

a. 33440 (10) - Alejandro, 15 (= De la suerte o virtud de Alejandro, I, 3, p. 327 E): Aristóbulo cuenta que Alejandro no tenía más de setenta talentos de viáticos para las tropas conducidas a Asia; Duris, que sólo tenía el alimento para treinta días, y Onesícrito, que incluso debía doscientos talentos.

a. 33441 (11) a) Clemente de Alejandría, Tapices, I, 139, 4, p. 86, 21 Stählin: Como dice Duris, desde la toma de Troya hasta el paso de Alejandro rumbo a Asia, transcurrieron mil años; de ahí, hasta † Evéneto, el arconte de Atenas, en el cual murió Alejandro, transcurrieron 11 años. b) Tzetzes, Posthoméricos, 770: Era el duodécimo día del mes Targelión ... era media noche ... en aquel momento, en aquella noche, Helánico de Lesbos canta, y con él también Duris, que los panaqueos tomaron Troya.

a. 33342 (14) Ateneo, XII, 38, p. 529 A: La mayoría, entre ellos también Duris, cuenta que Sardanápalo murió atravesado por Arbaces, que estaba indignado porque alguien de esa calaña fuera su rey.

a. 332/1 43 (15) Plinio, Historia natural, XXXVI, 79: Quienes escribieron acerca de estas pirámides son Heródoto, Evémero, Duris de Samos ...

44 (36) Escolios sobre Licofrón, 848: El Nilo al fluir divide Etiopía de Libia. Algunos, como Duris, dicen que las fuentes del Nilo están en Libia.

45 (48) Estéfano de Bizancio, s. v. Av̉ooís (Oasis): Ciudad de Egipto ... Heródoto y Duris la llamaron "isla de los dichosos".

a. 329/8? 46 (18) Plutarco, Alejandro, 46: La mayoría dice que allí (en el Orecartes, él creía que se trataba del Tanais) la amazona vino hacia Alejandro ... Aristóbulo, Cares el ujier, Ptolomeo ... y además de éstos, Hecateo de Eretria, Filipo de Calcis y Duris de Samos dicen que esto es una invención. 


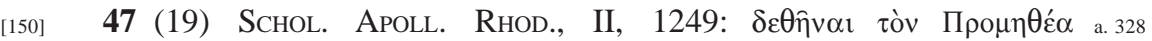

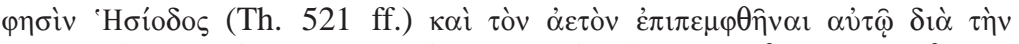

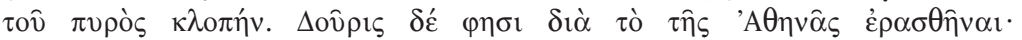

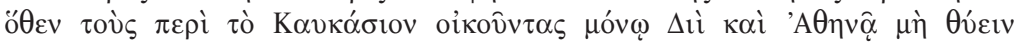

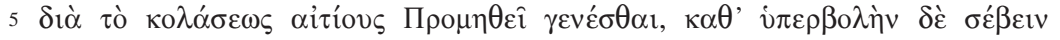

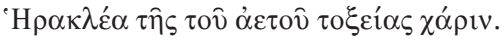

48 (19a) Plin., NH, VII, 30: Duris Indorum quosdam cum feris a. $327 / 6$ coire mixtosque et semiferos esse partuus. in Calingis eiusdem Indiae gente quinquennes concipere feminas, octavum vitae annum non ex-

10 cedere. et alibi cauda villosa homines nasci pernicitatis eximiae, alios auribus totos contegi.

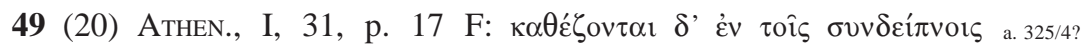

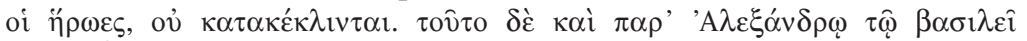

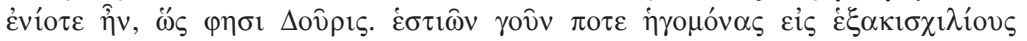

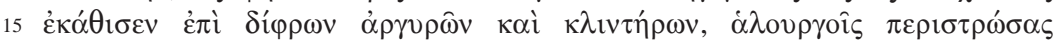
i $\mu \alpha$ tíors.

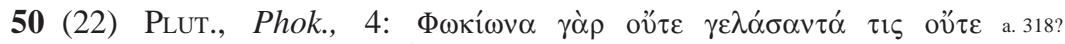

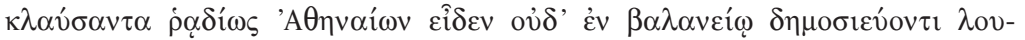

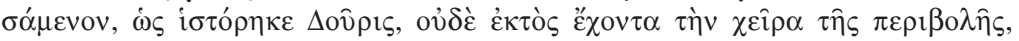

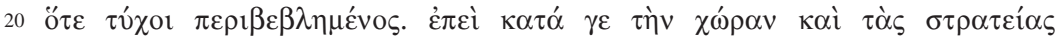

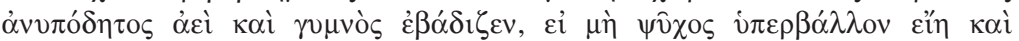

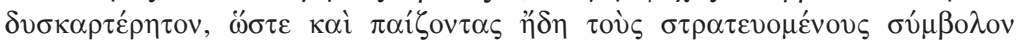

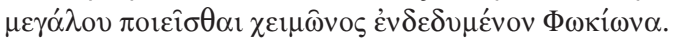

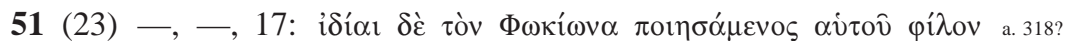

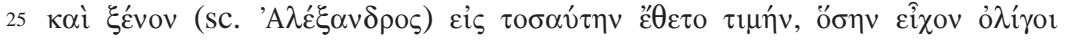

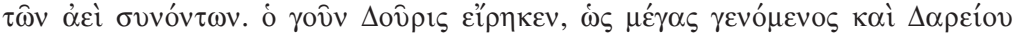

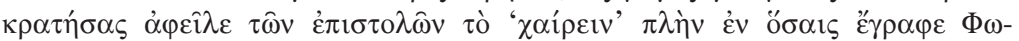

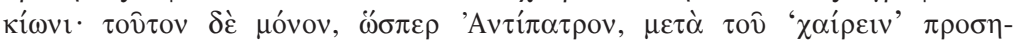

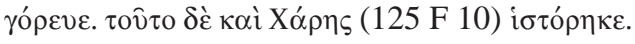

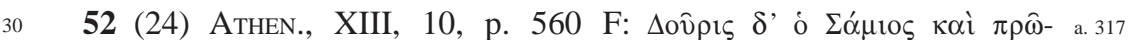

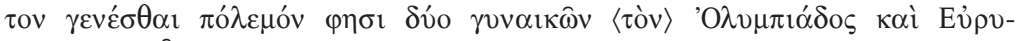

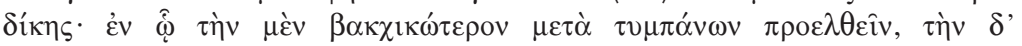

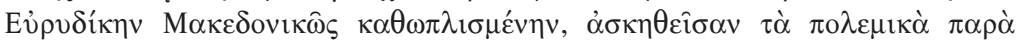

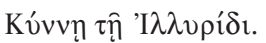

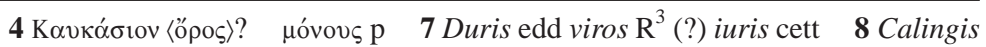

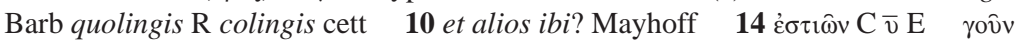

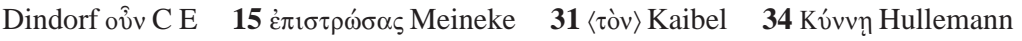
Kaibel (Diyllos 73 F 1; Hieron. -Diod. XIX 52, 5; Satyros Athen. XIII 557 C) Kvvvóṿฺ A (Arrian. Phot. bibl. 92 p. 70a 42. Kvvóvvn Polyaen. Strat. VIII 60) 
a. 32847 (19) Escolios sobre Apolonio De RodAs, II, 1249: Hesíodo dice que [150] Prometeo fue encadenado, y que se le envió un águila por el robo del fuego. Duris dice que por enamorarse de Atenea; que, por eso, los que viven alrededor del Caúcaso son los únicos que no les ofrecen sacrificios ni a Zeus ni a Atenea, por ser los causantes del castigo de Prometeo, pero veneran muchísimo a Heracles por lanzarle sus flechas al águila.

a. 327/6 48 (19a) PLINIO, Historia natural, VII, 30: Duris dice que ciertos indios tienen relaciones sexuales con las fieras, y que de esta unión nacen mitad fieras y mitad hombres; y que en Calinguis, una raza de la misma India, las mujeres conciben de cinco años, y no rebasan el octavo año de vida; que en otra parte nacen hombres de extraordinaria velocidad, con cola peluda, y que otros se cubren todos con las orejas.

a. 325/4? 49 (20) Ateneo, I, 31, p. 17 F: En los convivios los héroes no se reclinan. Esta costumbre existía también en la corte del rey Alejandro, como dice Duris. En efecto, una vez que invitó a unos seis mil caudillos, los sentó en sillas de plata y en sillones, habiéndolos cubierto con telas de púrpura.

a. 318? 50 (22) Plutarco, Foción, 4: Según ha contado Duris, ninguno de los atenienses vio fácilmente que Foción riera, llorara, se lavara en un baño público o que tuviera la mano fuera del manto, cuando casualmente lo ceñía. En efecto, si no hacía un frío exagerado y difícil de soportar, iba siempre descalzo y sin túnica, tanto al campo como a la milicia, de manera que, incluso en broma, los soldados hacían a Foción vestido, símbolo de un crudo invierno.

a. 318? 51 (23) —, —, 17: Después de que Alejandro hizo a Foción su amigo y huésped personal, lo tenía en tan grande estima, como a pocos de los que siempre lo acompañaban. Ciertamente Duris dijo que, ya cuando llegó a ser Magno y después de dominar a Darío, quitó de sus cartas el saludo "querido", excepto en las que le escribía a Foción, pues sólo a éste, como a Antípatro, lo saludaba con "querido". Esto lo ha contado también Cares.

a. 31752 (24) Ateneo, XIII, 10, p. 560 F: Duris de Samos dice que también la primera guerra de dos mujeres fue la de Olimpia y Eurídice; en ésta, la una avanzó como bacante, acompañada de tambores, y la otra, Eurídice, armada a la manera de los macedonios, pues había sido entrenada en asuntos militares por Cina, la iliria. 


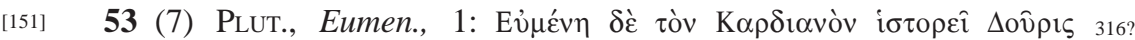

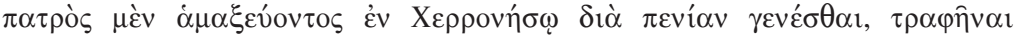

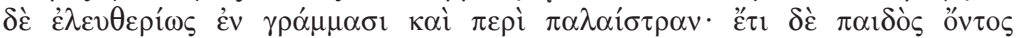

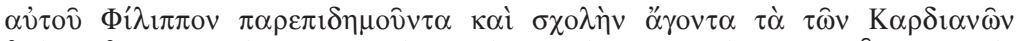

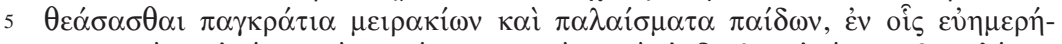

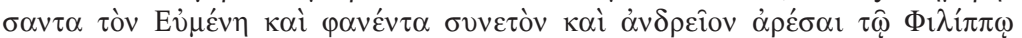

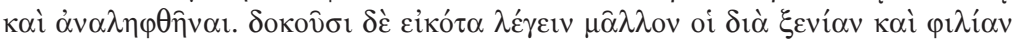

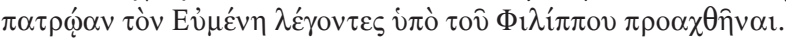

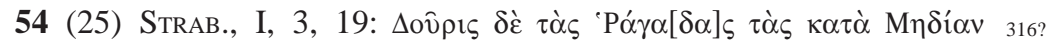

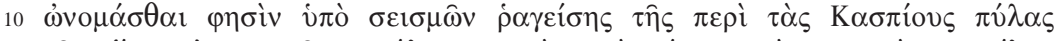
$\gamma \eta \bar{\varsigma}$,

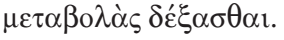

55 (33) Plin., NH, VIII, 143: is vero (sc. canis) cui nomen Hyr- a. 281 cani reddit Duris accenso regis Lysimachi rogo iniecit se flammae.

15

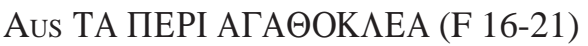

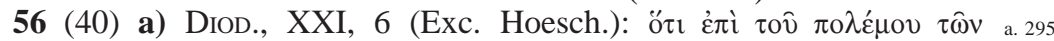

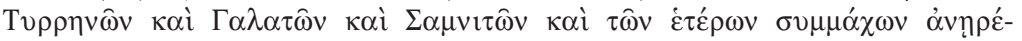

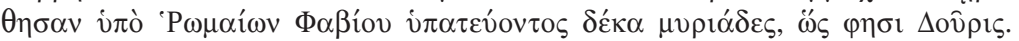

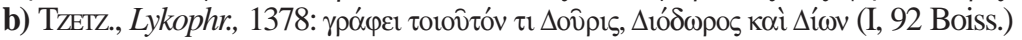

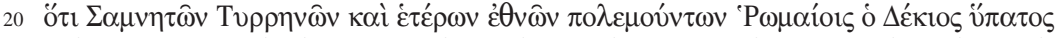

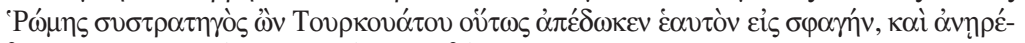

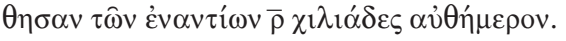

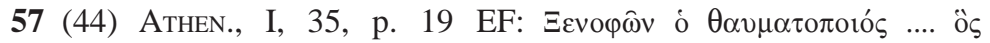

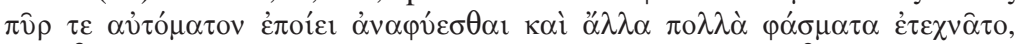

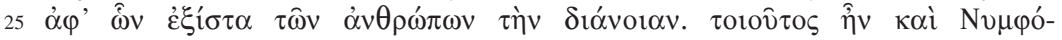

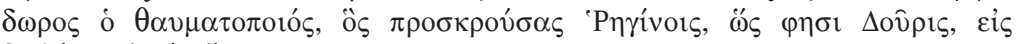

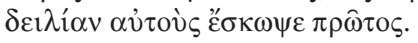

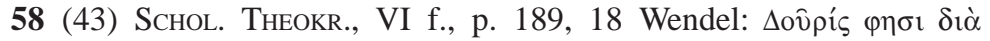

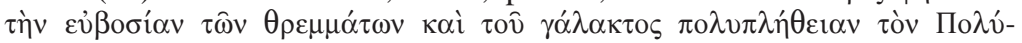

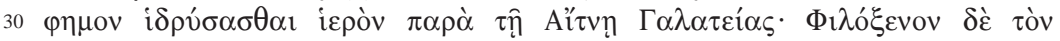

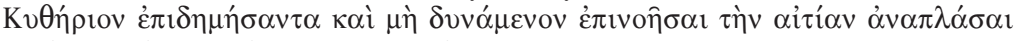

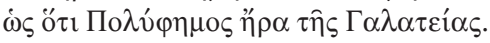

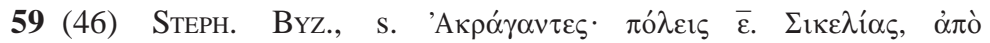

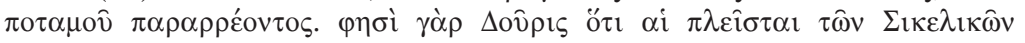

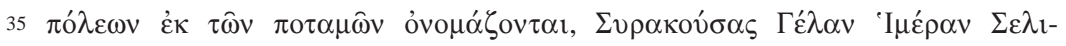

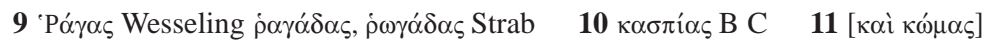

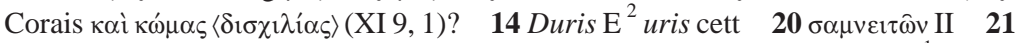

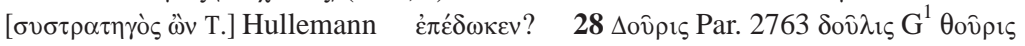

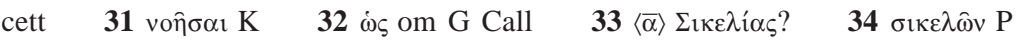

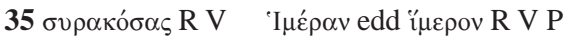


316? 53 (7) Plutarco, Eumenes, 1: Duris cuenta que Eumenes de Cardia [151] fue hijo de un padre que, a causa de su pobreza, era carretero en el Quersoneso, pero que fue educado liberalmente en las letras y en la palestra; cuenta además que, cuando él todavía era niño, Filipo, que andaba por ahí y tenía tiempo libre, vio los pancracios de los jóvenes cardios y las luchas de los niños, y que Eumenes, sobresaliendo entre éstos y mostrándose inteligente y valiente, le hizo gracia a Filipo y fue recogido. Sin embargo, parecen decir cosas más verosímiles quienes dicen que Filipo se llevó a Eumenes por hospitalidad y benevolencia paternal.

316? 54 (25) Estrabón, I, 3, 19: Duris afirma que Ragadas, la que está en Media, fue llamada así porque la tierra que está en torno a las puertas caspias, se desgarró a causa de unos sismos, de manera que se destruyeron famosas ciudades y pueblos, y los ríos sufrieron diversos cambios.

a. 28155 (33) Plinio, Historia natural, VIII, 143: Este perro, al cual Duris le da el nombre de Hircano, cuando ya estaba prendida la hoguera del rey Lisímaco, se arrojó a las llamas.

\section{De EN TORNO a AGATOCLES}

a. 29556 (40) a) Diodoro, XXI, 6 (Exc. Hoesch): Que en la guerra entre los tirrenos, los gálatas, los samnitas y los otros aliados, cuando era cónsul Fabio, los romanos mataron a cien mil, según dice Duris. b) TzeTzes, Comentarios sobre Licofrón, 1378: Algo semejante escriben Duris, Diodoro y Dión: que, cuando los samnitas, los tirrenos y otros pueblos peleaban contra los romanos, Decio, el cónsul de Roma, que era colega de Torcuato, así se entregó él mismo a la masacre, y fueron muertos cien millares de enemigos ese mismo día.

57 (44) Ateneo, I, 35, p. 19 EF: Jenofonte, el prestidigitador ... el que hacía brotar fuego espontáneamente y ejecutaba diestramente otros muchos trucos de magia, con los cuales confundía el pensamiento de los hombres. Así era Ninfodoro, el prestidigitador que, según Duris, cuando fue ofendido por los reginos, fue el primero en ridiculizarlos por su cobardía.

58 (45) Escolios sobre Teócrito, VI, f p. 189, 18 Wendel: Duris dice que, por la buena calidad de los animales y por la abundancia de leche, Polifemo erigió en el Etna el templo de Galatea; que, cuando Filoxeno estuvo en Citerio y no pudo entender la causa, inventó que fue porque Polifemo se había enamorado de Galatea.

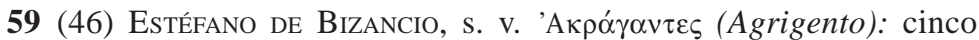
ciudades de Sicilia, a partir de un río que pasa por ahí. Duris dice que la mayoría de las ciudades sicilianas toman su nombre de los ríos: Siracusa, 


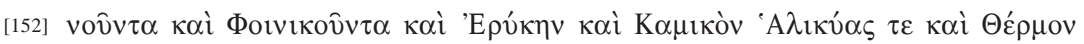

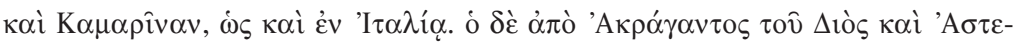

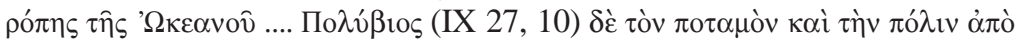

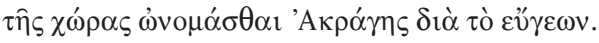

Aus DEN $\Sigma$ AMI $\Omega$ N $\Omega$ POI (F 22-26)

60 (47) Athen., XII, 30, p. 525 EF: $\pi \varepsilon \rho \grave{i} \delta \dot{\varepsilon} \tau \hat{\eta} \varsigma \Sigma \alpha \mu i ́ \omega v$ $\tau \rho v \varphi \hat{\eta} \varsigma$

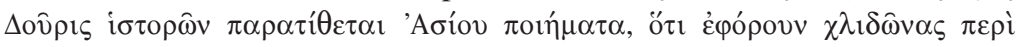

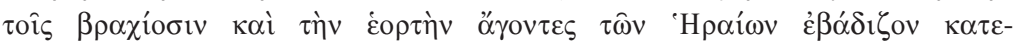

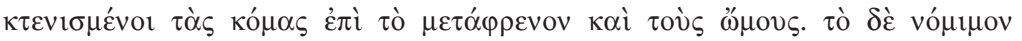

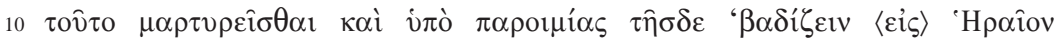

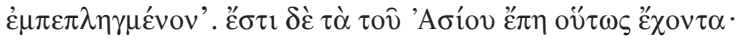

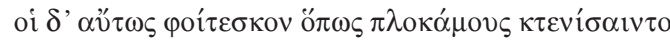

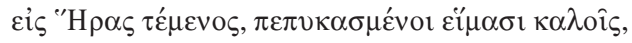

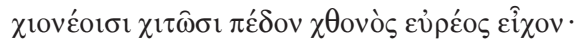

15

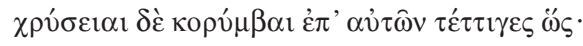

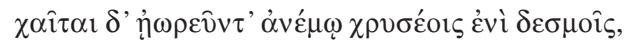

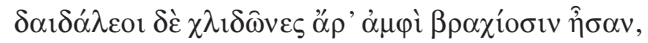

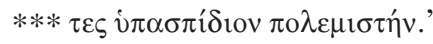

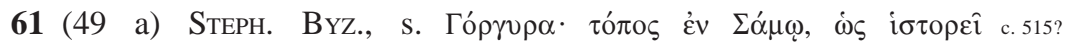

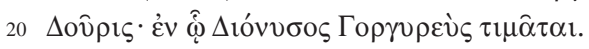

62 (-) Proverb. Cod. Paris., gr. 676 (S: Bresl. Phil. Abh. II a. 588

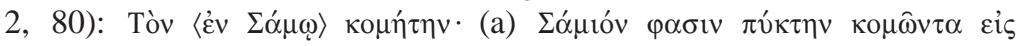

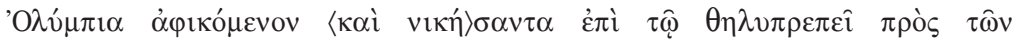

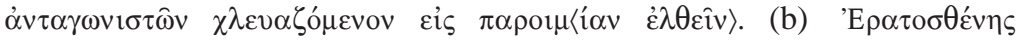

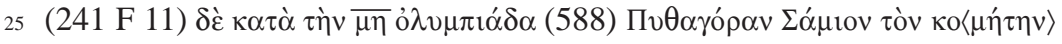

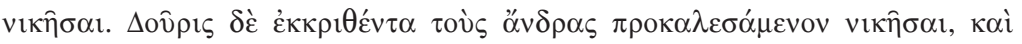

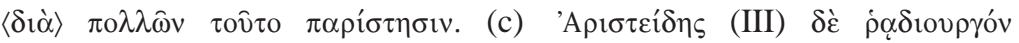

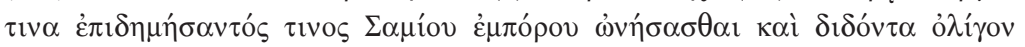

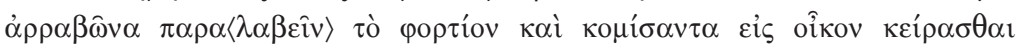

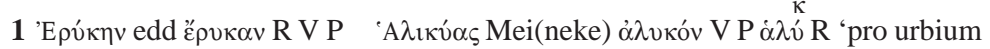
nominibus nomina fluviorum posuisse videtur excerptor' Berkel $\Theta \varepsilon ́ p \mu \alpha$ ? Mei

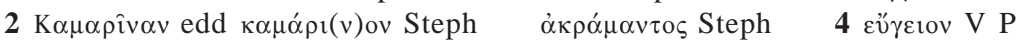

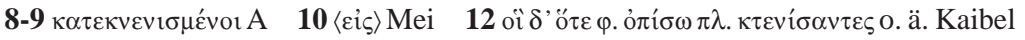

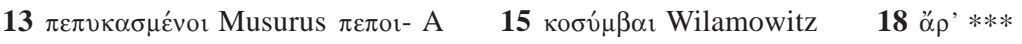

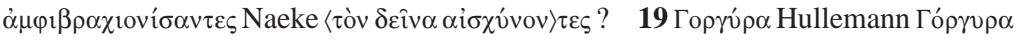

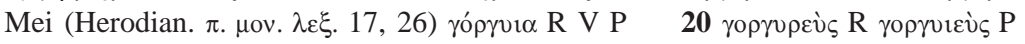

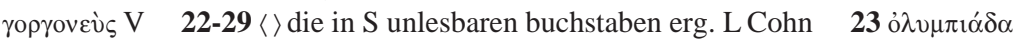

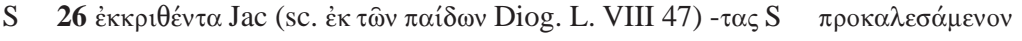

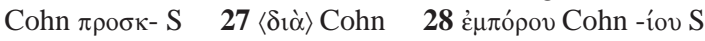


Gela, Himera, Selinunte, Fenicunta, Érice, Cámico, Halicata, Termón y [152] Camarina, así, también en Italia. Otros [dicen que esas ciudades se llaman así] a partir de Acragas, el hijo de Zeus y Astérope, la hija de Océano ... Pero Polibio (IX, 27, 10) dice que el río y la ciudad toman su nombre a partir de la región de Acragas, a causa de su fertilidad.

De Los ANALES DE SAMos

60 (47) Ateneo, XII, 30, p. 525 EF: Duris, contando acerca del lujo de los samios, cita unos poemas de Asio, “... que llevaban unas pulseras en los brazos y, cuando celebraban la fiesta de Hera, marchaban con los cabellos bien peinados sobre espalda y hombros". Esta costumbre está atestiguada también por el siguiente proverbio: "marchar a la fiesta de Hera con el cabello trenzado". Son versos de Asio los que a continuación se leen:

Así, cuando ellos peinaban sus trenzas, iban al recinto de Hera, cubiertos con ropas hermosas; tenían el piso de la amplia tierra cubierto con túnicas níveas. Sobre ellos había áureos broches como cigarras.

Sus cabelleras ondeaban con el viento entre listones dorados, pues había adornos metálicos alrededor de los brazos, *** a un guerrero cubierto con un broquel.

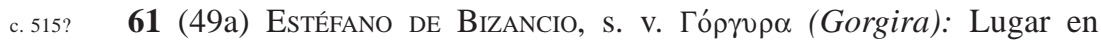
Samos, como cuenta Duris, donde es honrado Dionisos gorgireo.

a. 58862 Proverbiorum codex parisinus graecus, 676 (S: Bresl. Phil. Abh. II, 2, 80): Al melenudo en Samos: (a) Dicen que él era un púgil samio de melena larga que llegó a Olimpia y, tras vencer a un afeminado, llegó a ser proverbio al ser objeto de burlas por parte de sus contrincantes. (b) Eratóstenes dice que el melenudo era Pitágoras de Samos, que venció en la XLVIII olimpiada. Duris dice que, separándose éste de los niños, llamó a los hombres para que vencieran; esto se encuentra en muchos autores. (c) Arístides dice que el melenudo era un listo que, estando de paso un mercader samio, le hizo unas compras y que, dando un pequeño pago simbólico, tomó la mercancía, y, llevándola a su casa, se cortó la melena para no ser reconocido; también dice que esto llegó a ser proverbio, 


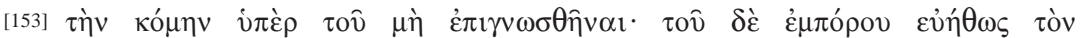

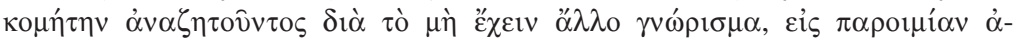

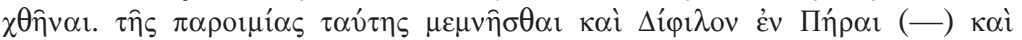
$\Phi i \lambda \eta \dot{\mu} \mu \nu \alpha \dot{\varepsilon} v \Delta \alpha \kappa \tau \nu \lambda i i_{(}(-)$.

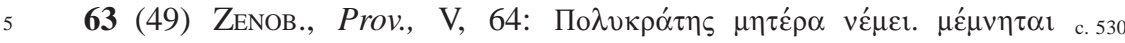

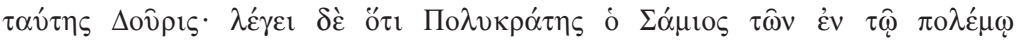

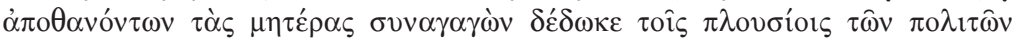

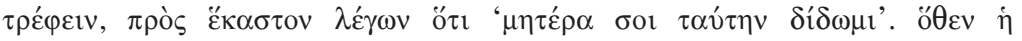

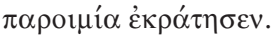

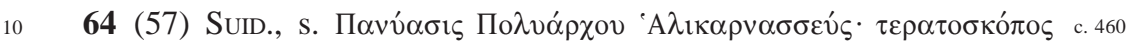

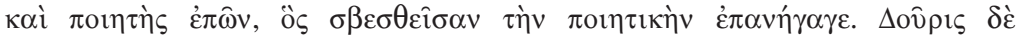

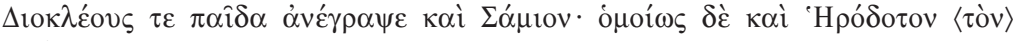
ఆoúpiov.

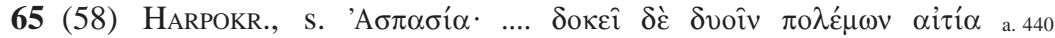

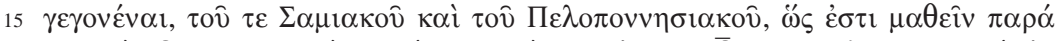

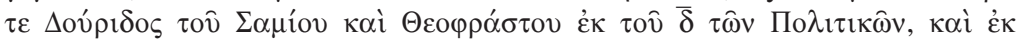
$\tau \hat{\omega} v$ 'A

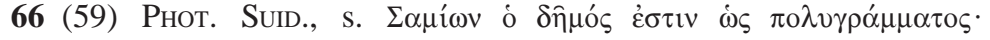

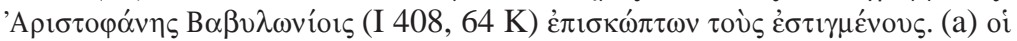

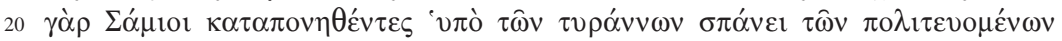

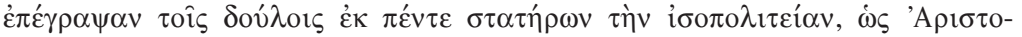

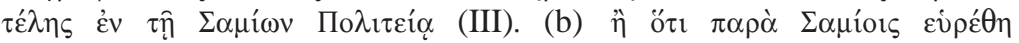

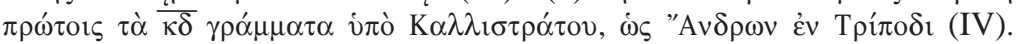

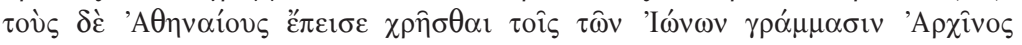

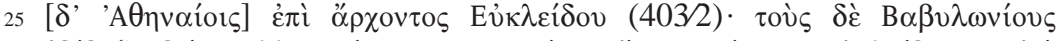

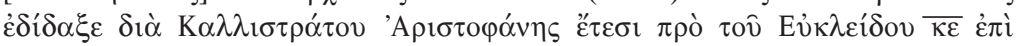

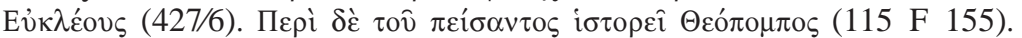

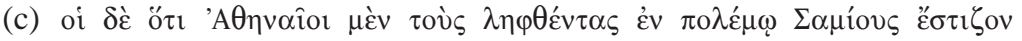

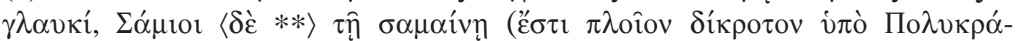

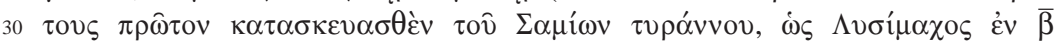

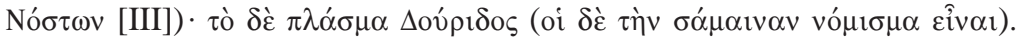

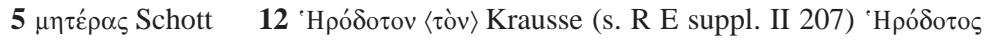

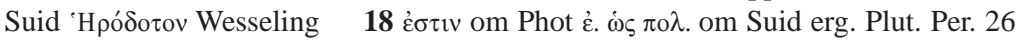

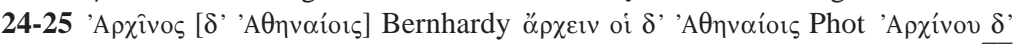

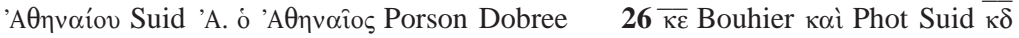

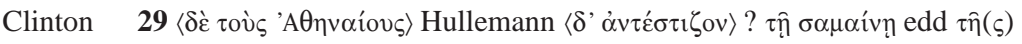

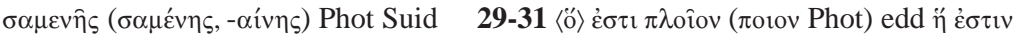

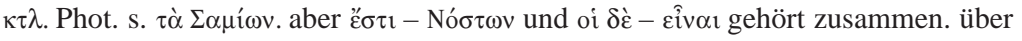

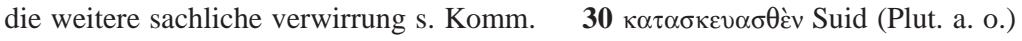
$\pi \alpha \rho \alpha-$ Phot 
porque el mercader, debido a que no tenía ninguna otra señal, buscaba [153] ingenuamente a un melenudo. Arístides dice que también Dífilo en Peras, y Filemón en Dáctilo hacen mención de este proverbio.

c. 53063 (49) Zenobio, Proverbios, V, 64: Polícrates distribuye madre. Duris menciona esta historia: dice que Polícrates de Samos, reuniendo a las madres de los muertos de guerra, las entregó a los ciudadanos ricos para que las alimentaran, diciendo a cada uno: "te doy a ésta como madre". De ahí surgió el proverbio.

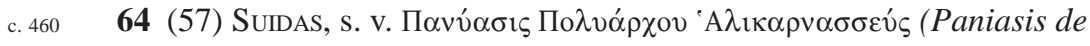
Halicarnaso, hijo de Poliarco): adivino y poeta de versos épicos, quien hizo resurgir la poética cuando estaba extinguida. Duris consignó que era samio, hijo de Diocles; igualmente, [cuenta] que Heródoto era turio.

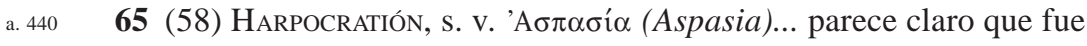
la causa de dos guerras, de la samia y de la peloponesa, como puede aprenderse en Duris de Samos, en el libro IV de los Políticos de Teofrasto y en los Acarnienses de Aristófanes.

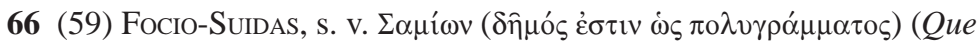
el pueblo de los samios es muy letrado); así dice Aristófanes en los Babilonios, mofándose de los tatuados. (a) Porque los samios, sometidos por los tiranos a causa de la carencia de ciudadanos, decretaron la igualdad de derechos para los esclavos por sólo cinco estateras, como dice Aristóteles en la Constitución samia. (b) O porque los samios fueron los primeros que inventaron las veinticuatro letras en tiempos de Calístrato, como dice Andro en el Trípode. Cuando Euclides (403/2 a.C.) era arconte, Arquino convenció a los atenienses de que usaran las letras de los jonios; y a través de Calístrato, Aristófanes se las enseñó a los babilonios, veinticinco años antes de Euclides, en tiempos de Eucleo (427/6 a.C.); Teopompo también habla de este convencimiento. c) Otros dicen que porque los atenienses tatuaron con una lechuza a los samios capturados en la guerra; los samios <a su vez tatuaron a los atenienses> con una samaina (una embarcación de dos bancos de remos, la cual primeramente fue construida en tiempos de Polícrates, el tirano de los samios, como dice Lisímaco en el libro II de De los retornos). La historieta es de Duris (otros dicen que la samaina era una moneda). 


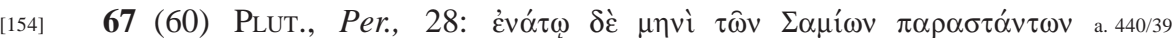

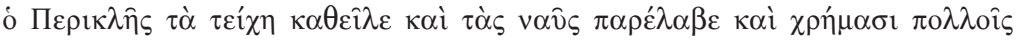

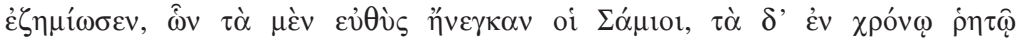

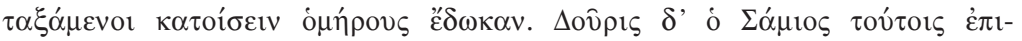

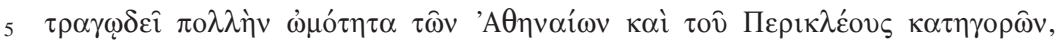

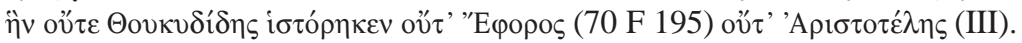

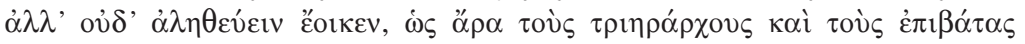

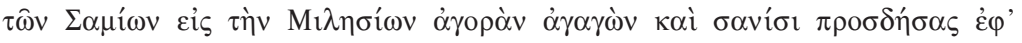

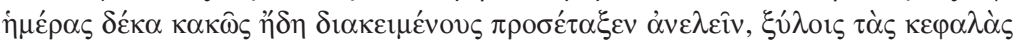

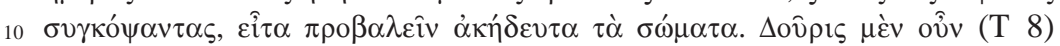

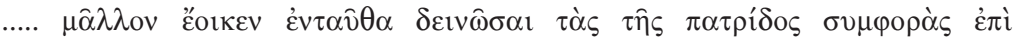

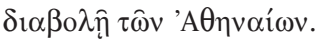

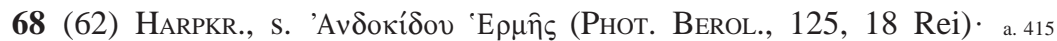

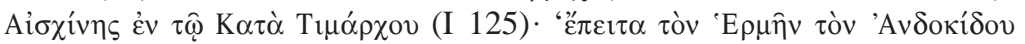

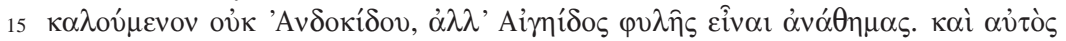

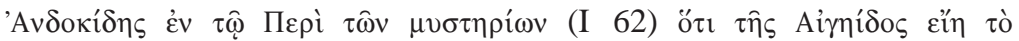

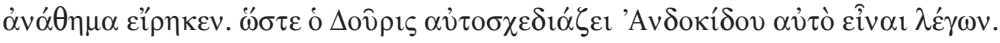

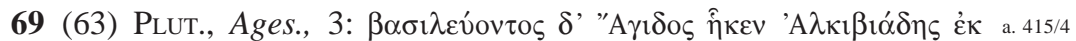

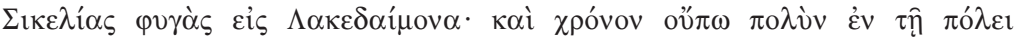

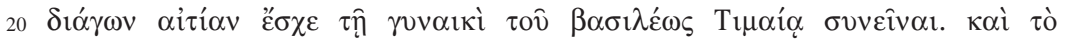

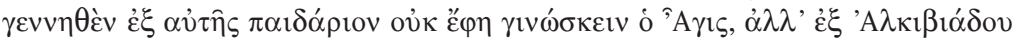

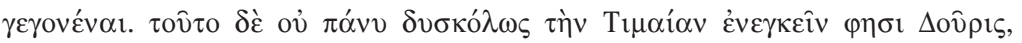

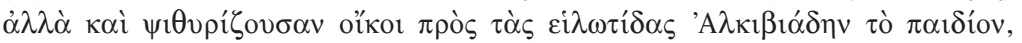
ov̉ $\Lambda \varepsilon \omega \tau v \chi i ́ \delta \eta v \kappa \alpha \lambda \varepsilon i ̂ v$.

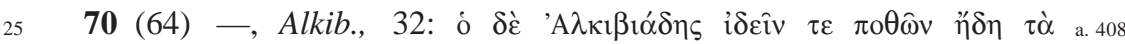

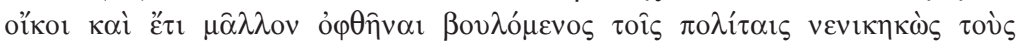

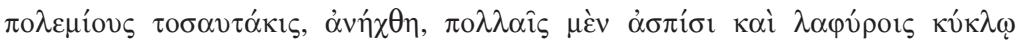

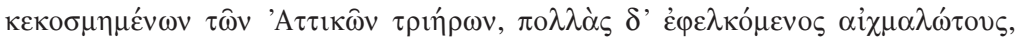

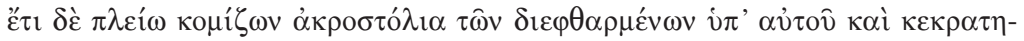

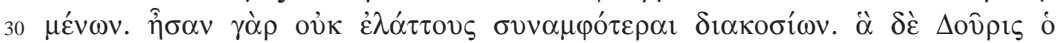

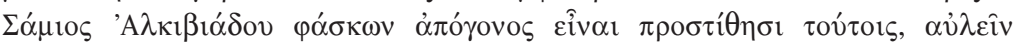

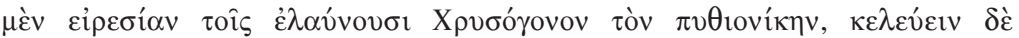

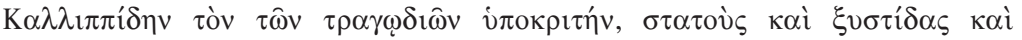

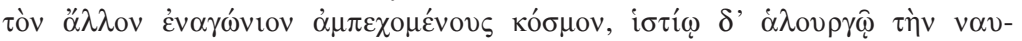

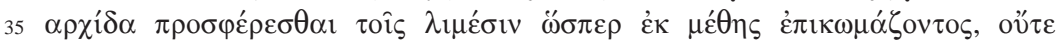

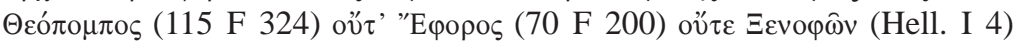

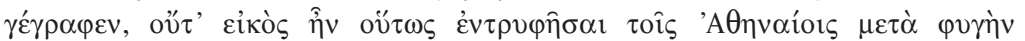

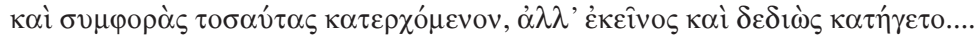

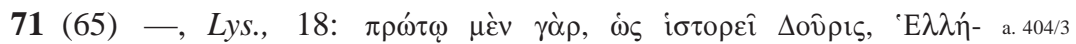

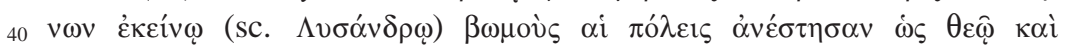


a. 440/39 67 (60) Plutarco, Pericles, 28: Habiéndose rendido los samios en el [154] noveno mes, Pericles destruyó sus murallas y tomó sus barcos y les impuso una multa muy grande, de la cual, los samios llevaron una parte inmediatamente, y, comprometiéndose a liquidar el resto en un tiempo convenido, entregaron rehenes. Duris de Samos dramatiza en estas cosas, acusando de gran crueldad a los atenienses y a Pericles, de la cual no hablan ni Tucídides, ni Éforo, ni Aristóteles. Mas tampoco parece decir la verdad, cuando dice que Pericles, condujo a los comandantes de la flota y a los marineros samios a la plaza de los milesios; que los ató a unos postes durante diez días y que, cuando ya estaban en mal estado, los mandó matar, destrozándoles las cabezas con palos, y que después tiró los cuerpos insepultos. En este pasaje, más bien parece que Duris (fr. 8) ... exagera los males de su patria, en afrenta de los atenienses.

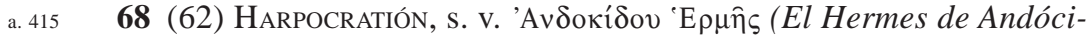
des) (Pнot., Berol., 125, 18, Rei): Esquines en Contra Timarco (I, 125): 'Luego dice que la estatua de Hermes, que es considerada como de Andócides, no era de Andócides, sino de la familia Egeida'. Y el mismo Andócides en Sobre los misterios (I, 62), afirma que la ofrenda es de la familia Egeida. De manera que Duris habla a la ligera diciendo que la ofrenda es de Andócides.

a. 415/4 69 (63) Plutarco, Agesilao, 3: Cuando Agis era rey, Alcibíades vino a Lacedemonia huyendo de Sicilia, y el haber tenido relaciones con Timea, la mujer del rey, fue la causa de su muy breve estancia en la ciudad. Y Agis dijo que no reconocía al niñito que había nacido de ella, pues era de Alcibíades. Duris dice que Timea no sobrellevó esto muy difícilmente, sino que en casa, incluso les cuchicheaba a sus esclavas que ella llamaba al niño Alcibíades, no Leotiquides.

a. 40870 (64) —, Alcibíades, 32: Alcibíades, ya deseando ver su patria y, más aún, queriendo ser visto por los ciudadanos tras haber vencido a los enemigos tantas veces, zarpó - adornadas las trirremes áticas con muchos escudos y despojos alrededor-, acarreando muchos prisioneros de guerra e incluso llevando muchos acrostolios de las naves que habían sido destruidas y dominadas por él; en efecto, unas y otras no eran menos de doscientas. Lo que a estos datos añade Duris de Samos, que afirma ser descendiente de Alcibíades — a saber, que Crisógono, el vencedor en los juegos píticos, ejecutaba en la flauta una canción para los remeros, y Calípides, el actor de tragedias, los animaba: ambos vestían un quitón y una túnica de tela fina y todo el demás ajuar dramático, y que la nave capitana se acercaba al puerto con una vela color púrpura, exactamente como si Alcibíades regresara de una borrachera-, no lo escribieron ni Teopompo ni Éforo ni Jenofonte, ni era verosímil que se pavoneara así ante los atenienses después del destierro y habiendo pasado tantas desgracias; más bien Alcibíades desembarcó incluso temeroso ...

a. 404/3 71 (65) —, Lisandro, 18: Pues, como dice Duris, a Lisandro, como primero de los griegos, las ciudades le erigieron altares como a un dios y le 


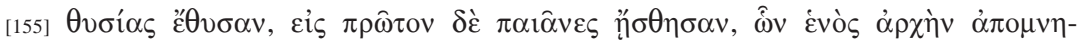

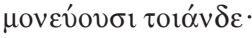

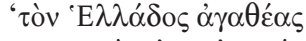

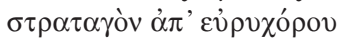

$$
\begin{aligned}
& \Sigma \pi \alpha \dot{\rho} \tau \alpha \varsigma \dot{v} \mu \nu \eta \dot{\sigma} \sigma o \mu \varepsilon v \hat{\omega}
\end{aligned}
$$

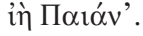

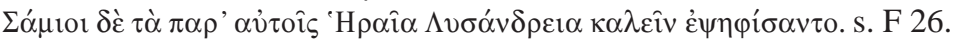

Aus ANDEREN SCHRIFTEN.

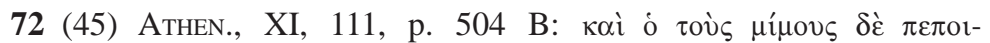

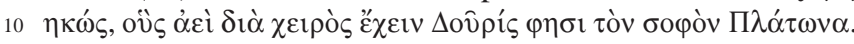

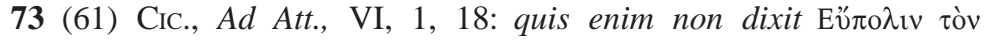
$\tau \eta \hat{~} \dot{\alpha} \rho \chi \alpha i \alpha \varsigma$ ab Alcibiade navigante in Siciliam deiectum esse in mare? redarguit Eratosthenes (241 F 19); adfert enim quas ille post id tempus fabulas docuerit. num idcirco Duris Samius, homo in historia diligens, 15 quod cum multis erravit, inridetur?

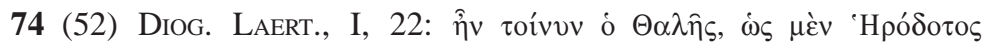

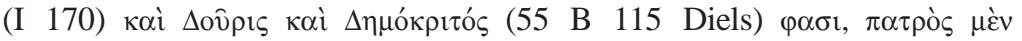

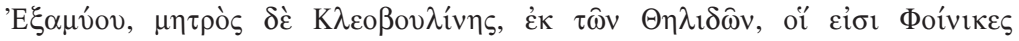

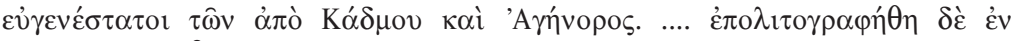

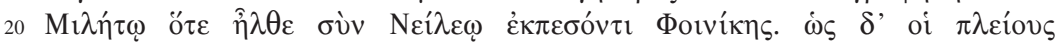

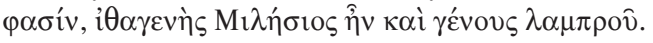

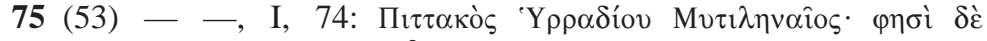

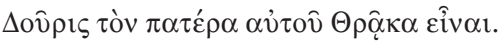

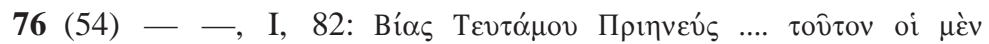

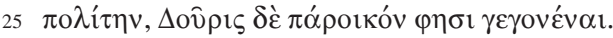

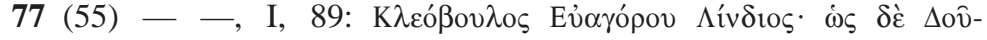

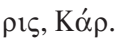

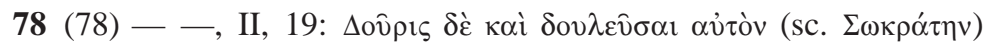

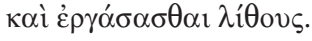

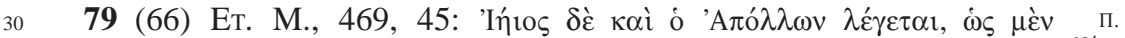

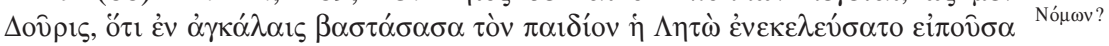
'ị́ı $\pi \alpha$ ıิ๊ov'.

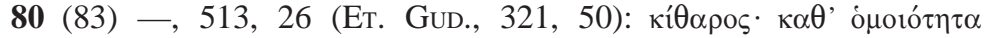

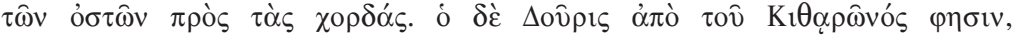

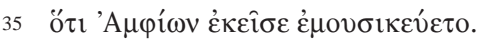

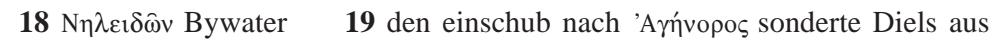

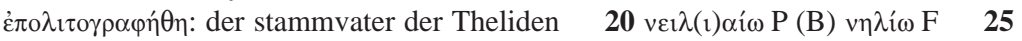

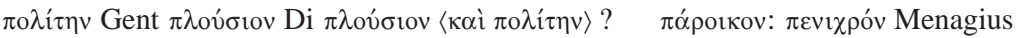

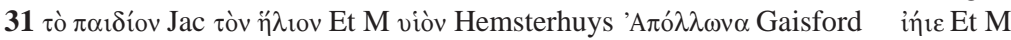


ofrecieron sacrificios; se oyeron peanes dirigidos a él, como primero; de [155] éstos se recuerda el principio de uno, que es éste:

De la Hélade muy divina,

al general de la anchurosa

Esparta, himnos cantemos:

¡oh, ea peán!

Los samios decidieron que entre ellos las fiestas a Hera se llamarían lisandreas.

DE OTROS ESCRITOS

72 (45) Ateneo, XI, 111, p. 504 B: Y Sofrón, el autor de mimos que, según dice Duris, el sabio Platón siempre tenía en las manos.

73 (61) Cícerón, Cartas a Ático, VI, 1, 18: ¿Pues quién no dice que Eupolis, el de la comedia antigua, fue lanzado al mar por Alcibíades cuando navegaba a Sicilia? Eratóstenes refuta esto, pues cita obras que él representó después de ese tiempo. Entonces, ¿por qué se ríen de que Duris de Samos, hombre diligente en historia, se equivocó con muchos otros?

74 (52) Diógenes Laercio, I, 22: Así pues, como dicen Heródoto (I, 170), Duris y Demócrito, Tales era hijo de Examio y de Cleobulina, de la familia de los telidas, que son fenicios nobilísimos, de los descendientes de Cadmo y Agenor... Fue hecho ciudadano de Mileto cuando llegó con Neleo que había sido expulsado de Fenicia. Según dice la mayoría, era legítimo milesio y de ilustre linaje.

75 (53) — , I, 74: Pítaco de Mitilene, el hijo de Hirradio; Duris dice que su padre era tracio.

76 (54) —, I, 82: Bías de Priene, el hijo de Téutamo... unos dicen que él nació ciudadano; Duris, que extranjero.

77 (55) —, I, 89: Cléobulo, el hijo de Evágoras, era lindio, o, según Duris, cario.

78 (78) —, II, 19: Duris dice que Sócrates fue esclavo y trabajó la piedra.

79 (66) Etymologicum magnum, 469, 45: También Apolo es llamado Ieio, según Duris, porque Leto, llevando al niñito en brazos, lo consoló diciendo "hieie paieon".

80 (83) - , 513, 26 (Etymologicum Gudianum, 321, 50), s. v. кí⿴囗⿱一一) (1. tórax; 2. pez lenguado): Por la similitud de sus huesos con las cuerdas [de la cítara]. Duris dice que a partir del Citerón, porque ahí tocaba Anfión. 


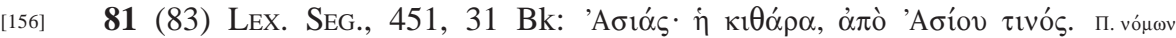

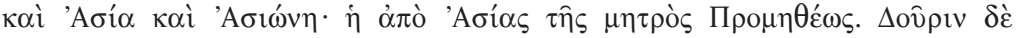

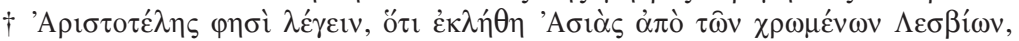

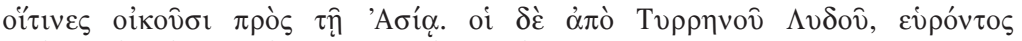

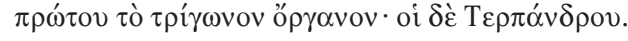

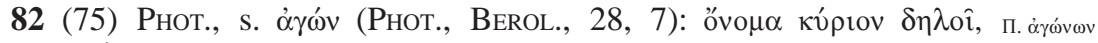

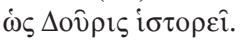

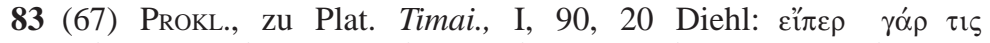

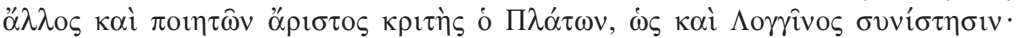

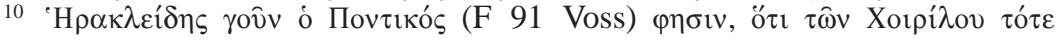

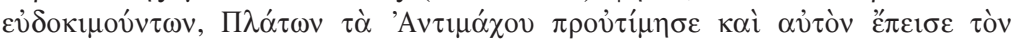

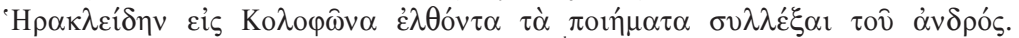

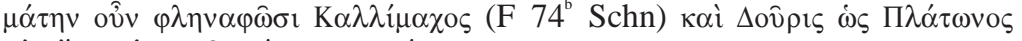

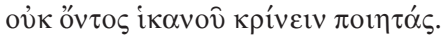

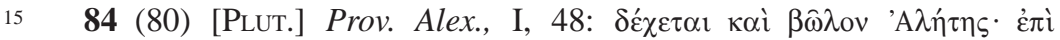

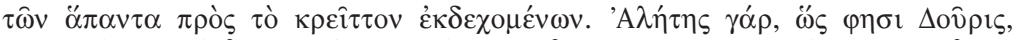

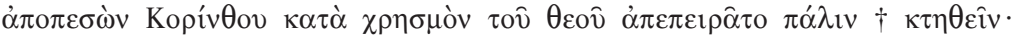

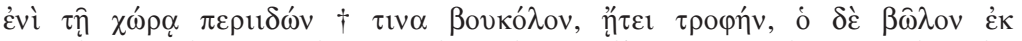

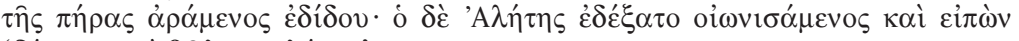

20

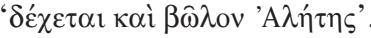

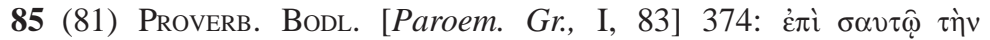

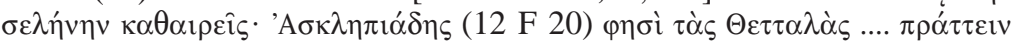

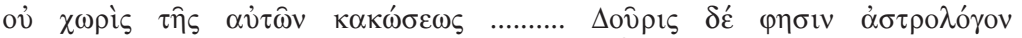

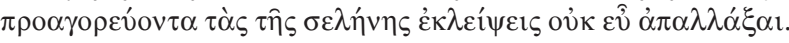

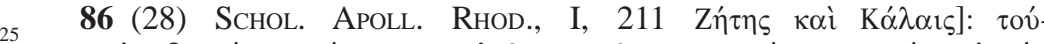

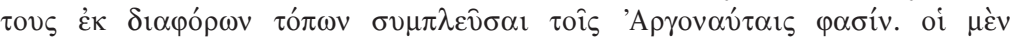

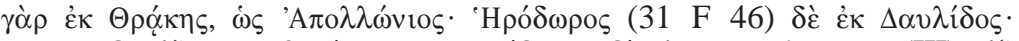

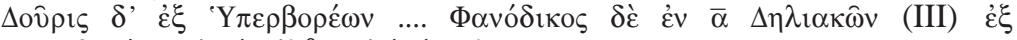

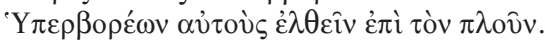

$30 \quad 87$ (39) — - - I, 501:

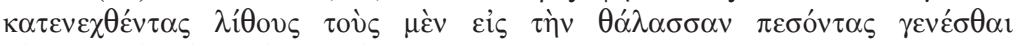

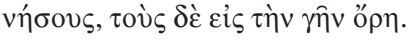

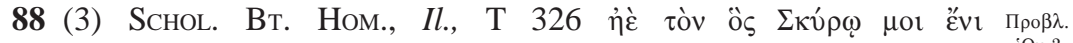

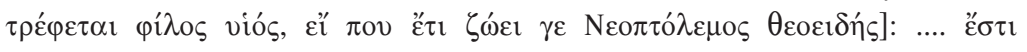

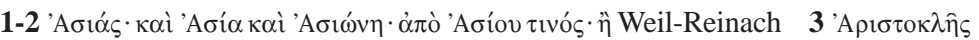

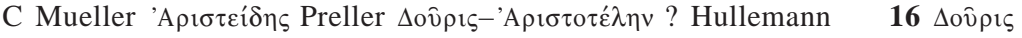

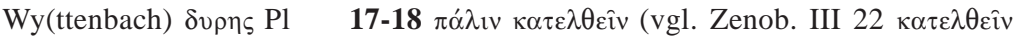

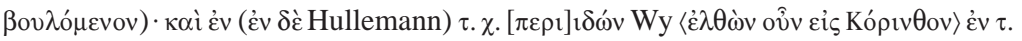

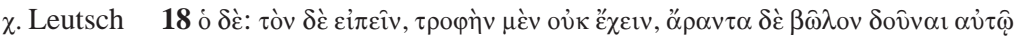

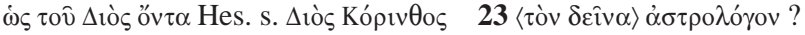


п. vónஸv 81 (83) Lexica Segueriana, 451, 31, Bekkeri Anecd., s. v. 'Aбı́́s (asiás, [156] también asia y asione): la cítara, llamada así a partir de cierto Asio. También es llamada asia y asione, o a partir de Asia, la madre de Prometeo. Duris afirma que $†$ Aristóteles dice que la cítara fue llamada asiás a partir de los lesbios que la usaron, los cuales viven en Asia; otros afirman que a partir de Tirreno el lidio, que fue el primero en diseñar el instrumento triangular; otros, que a partir de Terpandro.

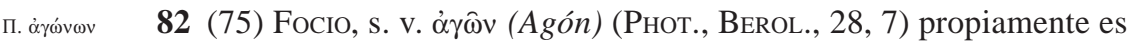
un nombre, como cuenta Duris.

83 (67) Proclo, In Platonis Timaeum commentaria, I, 90, 20 Diehl: Aunque haya algún otro, Platón también es un excelente juez de poetas, como lo muestra incluso Longino. En efecto, Heráclides el póntico dice que, cuando los versos de Corilo gozaban de buena reputación, Platón prefirió los versos de Antímaco, y convenció al mismo Heráclides de que, yendo a Colofón, reuniera los poemas de ese hombre. En vano, pues, Calímaco y Duris mascullan en el sentido de que Platón no era capaz de juzgar a los poetas.

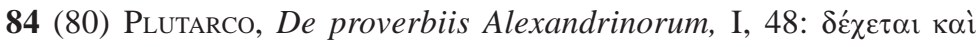
$\beta \hat{\omega} \lambda$ ov 'A $\lambda$ ínฺ (Aletes también recibe un terrón). Se dice de los que reciben cualquier cosa por algo mejor. Aletes, como dice Duris, después de salir de Corinto, de acuerdo con el oráculo del dios, intentaba nuevamente $\dagger$ recuperarlo; habiendo visto en la región † a un pastor, le pidió alimento, y éste, sacando un terrón de su alforja se lo dio. Aletes lo recibió, presintiendo que se cumplía el oráculo, diciendo: "Aletes también recibe un terrón".

85 (81) Proverbia Bodleiana [Corpus paroemiographorum graecorum,

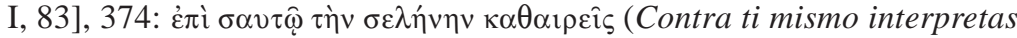
la luna). Asclepiades dice que las tesalias ... no actuaban sin dañarse a sí mismas ... Duris dice que un astrólogo que predice los eclipses de la luna, no sale bien librado.

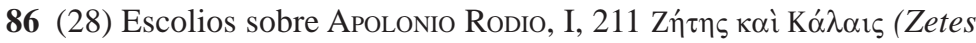
y Calais)]: se dice que éstos llegaron para navegar con los argonautas desde lugares diferentes; unos, que de Tracia, como Apolonio; Herodoro, que de Daúlide; Duris, que de los Hiperbóreos, Fanódico en el libro I de las Deliacas también dice que desde los Hiperbóreos.

87 (39) —, I, 501: Duris dice que las piedras arrojadas por los gigantes se convirtieron en islas, las que cayeron en el mar, y las que cayeron en la tierra, en montes.

Провл. 88 (3) Escolio BT sobre Homero, Ilíada, XIX, 326.

'O $\mu$.?

“ $\mathrm{O}$ a aquel a quien en Esciro me educan, mi hijo querido, ¡si en algún lado vive aún!, de aspecto divino, Neoptólemo!”... 


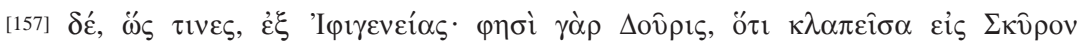

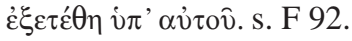

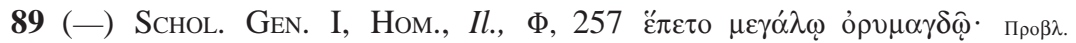

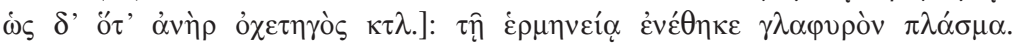

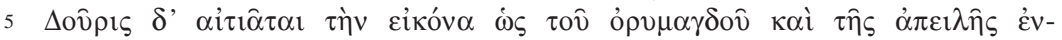

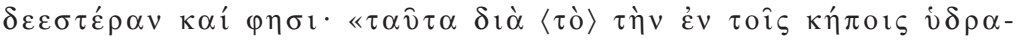

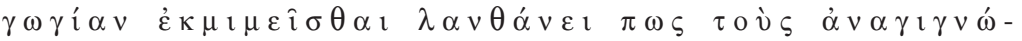

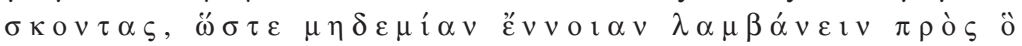
$\pi \varepsilon \pi$ o i $\eta \kappa \varepsilon . »$

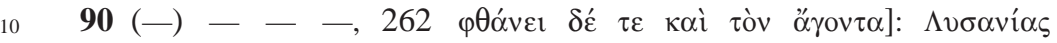

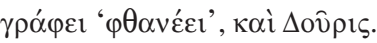

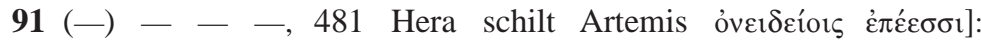
$\Delta$ ov̂pı ö

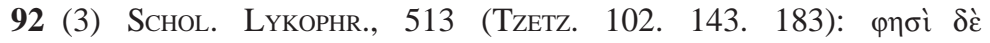

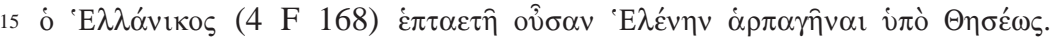

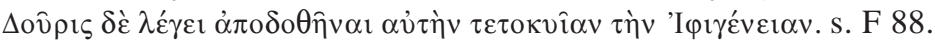

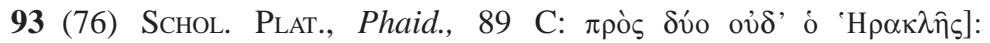

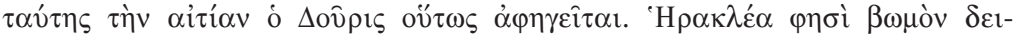

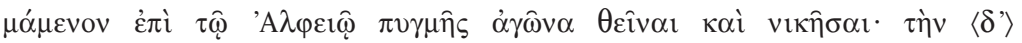

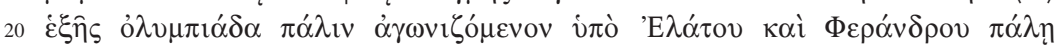

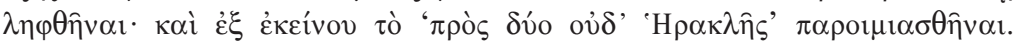
s. 3 F 79.

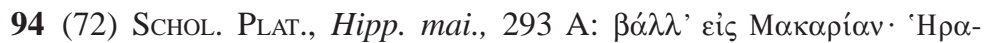

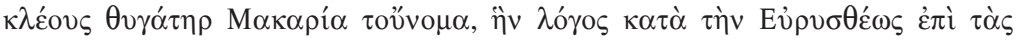

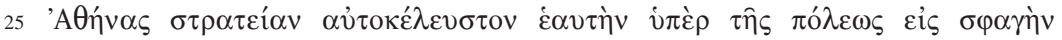

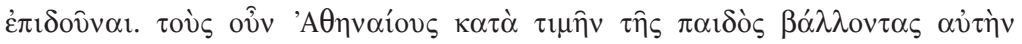

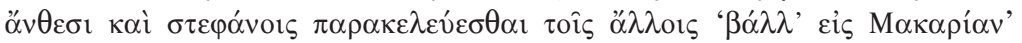

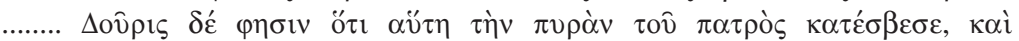

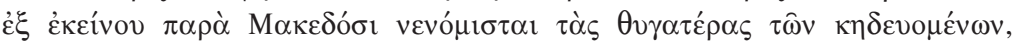

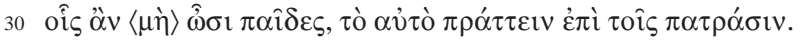

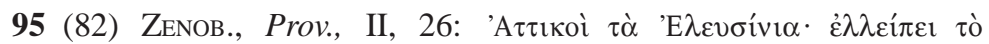

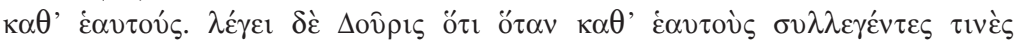

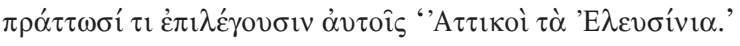

96 (68) -, 一, II, 28 (Anon. in Aristot. Rhet., II, 21; Comm.

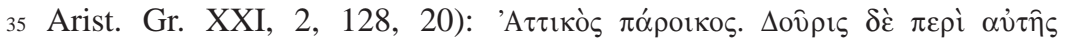

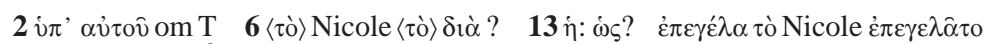

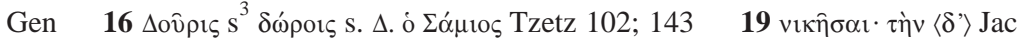

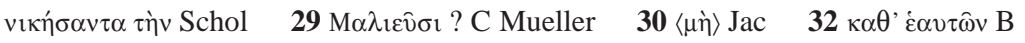

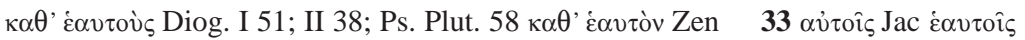

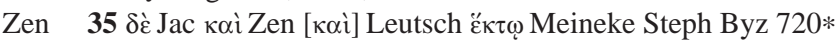


Neoptólemo es, según algunos, hijo de Ifigenia: Duris dice que ésta, [157] después de que fue llevada secretamente a Esciro, fue sacada por Aquiles.

Провл. $\quad 89$ (-) Escolio Genavense I sobre Homero, Ilíada, XXI, 257 Seguía con un gran alboroto, como cuando un hombre lleva el agua por zanjas, etc.]: en la interpretación se ha dado una figura sinuosa. Duris se hace la imagen vaga de un alboroto y de una amenaza, y dice: "esto, por imitar el paso del agua en los jardines, es un tanto oscuro para los lectores, de manera que no se obtiene ninguna idea respecto a lo que está escrito".

” $90(-)$ - 262: Se adelanta ( $\varphi \tau o ́ v \varepsilon ı)$ al que [la] lleva]: Lisanias escribe ' $\varphi \tau \alpha v \varepsilon ́ \varepsilon \iota '$, y Duris también.

” $91(-)$ - 481 Hera increpa a Artemis con palabras hirientes]: Duris dice que la madrastra se halla en una situación amarga, por eso sonrió sardónicamente.

„(?) 92 (3) Escolios sobre Licofrón, 513 (TzETZEs, 102, 143, 183): Helánico dice que cuando Helena tenía siete años, fue robada por Teseo. Duris dice que fue devuelta cuando dio a luz a Ifigenia. fr. 88.

93 (76) Escolios sobre Platón, Fedón, 89 C: Contra dos, ni siquiera Heracles]: Duris explica así la causa de este proverbio. Dice que Heracles, habiendo construido el altar en el Alfeo, instituyó la competencia del pugilato y venció; que en la siguiente olimpiada, compitiendo de nuevo, fue vencido por Elato y Ferandro, y que desde entonces surgió el proverbio: "Contra dos, ni siquiera Heracles".

94 (72) Escolios sobre Platón, Hipias mayor, 293 A: Arrójale a Macaria: la hija de Heracles se llama Macaria; se cuenta que, en la expedición militar de Euristeo contra Atenas, ella misma se entregó espontáneamente al sacrificio en favor de la ciudad; que, entonces, los atenienses, en honor a la niña, arrojándole flores y coronas exhortaban a los otros con estas palabras: "Arrójale a Macaria"... Duris dice que ella encendió la pira de su padre, y que, desde entonces, entre los macedonios se acostumbra que las hijas de los que reciben los honores fúnebres, si éstos no tienen hijos, hagan lo mismo con sus padres.

95 (82) Zenobio, Proverbios, II, 26: Los áticos, las fiestas de Eleusis; se omite el celebran entre ellos. Duris dice que, cuando algunos hacen algo, tras haberse reunido entre ellos, se dicen entre sí: "Los áticos [celebran entre ellos] las fiestas de Eleusis".

96 (68) - , - II, 28 (ANónimo, en Aristóteles, Retórica, II, 21; Commentaria in Aristotelem graeca, XXI, 2, 128, 20): Un ático cerca de 


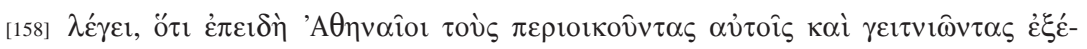

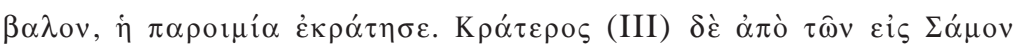

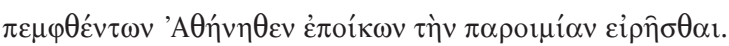


casa. Acerca de este proverbio, Duris dice que tuvo vigencia cuando los [158] atenienses expulsaban a los que vivían alrededor de su casa y a los que eran sus vecinos. Crátero cuenta que el proverbio se dice a partir de los colonizadores enviados de Atenas a Samos. 


\section{BIBLIOGRAFÍA}

Ediciones

JАСОву, F., Die Fragmente der griechischen Historiker II, Leiden, E. J. Brill, 1961, pp. 136-158.

Müllerus, C., Fragmenta historicorum graecorum II, París, A. F. Didot, 1848, pp. 466-488.

Fuentes

Aristófanes, Obras completas, trad. D. Federico Baráibar y Zumárraga, Buenos Aires, Librería El Ateneo, 1954.

Aristóteles, Fragmenta, V. Rose (ed.), Stuttgart, B. G. Teubner (Bibliotheca Scriptorum Greacorum et Romanorum Teubneriana), 1967.

Atheneus, The Deipnosophists, trad. Gulick Burton, Cambridge, Harvard University Press (The Loeb Classical Library), 1961 ( $2^{\circ}$ reimp.), 7 vols.

Cicerón, Cartas a Ático II, vers. Amparo Gaos S., México, Universidad Nacional Autónoma de México (Bibliotheca Scriptorum Graecorum et Romanorum Mexicana), 1976.

Clement of Alexandria, The exhortation to the Greeks. The rich man's salvation, trad. G. W. Butterworth, Cambridge, Harvard University Press, 1968 (4 reimp.).

Comicorum Atticorum fragmenta, U. Hes (ed.), trad. T. Kock, Leipzig, Teubner, 1976.

Corpus paroemiographorum Graecorum: Zenobius, Diogenianus, Plutarchus, Gregorius Cyprius, E. L. Leutsch \& F. G. Schneidewin (eds.), Hildesheim, Georg Olms Verlagsbuchhandlung, 1965 ( $2^{\circ}$ reimp.).

Demóstenes \& Esquines, Elocuencia griega: discursos completos, Francisco de P. Samaranch \& J. Palli Bonet, Madrid, Aguilar, 1969.

Diodore de Sicile, Bibliothèque historique IV, trad. A. F. Miot, Paris, L'imprimiere royale, 1836.

Diodorus Siculus, The library of history XI, trad. Francis Walton, Cambridge, Harvard University Press (The Loeb Classical Library, 409), 1968 ( $1^{\circ}$ reimp.).

Diogenes Laertius, Lives of eminent philosophers, trad. R. D. Hicks, Cambridge, Harvard University Press (The Loeb Classical Library, 184), 1950 ( $3^{\circ}$ reimp.).

Dionisio de Halicarnaso, Tres ensayos de crítica literaria, trad. Vicente Bécares B., Madrid, Alianza editorial, 1992. 
Estrabón, Geografía, trad. y nts. J. L. García Ramón, Madrid, Gredos, 1991.

Fragmenta poetarum comoediae antiquae II, Augustus Meineke (ed.), Berlín, W. de Gruyter, 1970.

Harpocrationis, Lexicon in decem oratores atticos, ed. G. Dindorfii, Groningen, Boumais Boekhuis N. V. Publishers, 1969.

Pausanias, Descripción de Grecia, trad. A. Tovar, Valladolid, Universidad de Valladolid, 1946.

-, Description of Greece III, vol. I, trad. S. Jones, Cambridge, Harvard University Press (The Loeb Classical Library), 1966 (4 reimp.).

Photius, Lexikon, introd., trad. y nts. S. A. Naber, Amsterdam, Adolf M. Hakkert Publisher, 1965.

Plinio, Cayo Segundo, Obras completas: Historia natural (libros I-VIII), trad. y nts. Francisco Hernández, México, Universidad Nacional Autónoma de México, 1966, vol. I.

—, Obras completas: Historia natural (libros IX-XXV), trad. y nts. Francisco Hernández, México, Universidad Nacional Autónoma de México, 1976, vol. II.

-, Obras completas: Historia natural (libros XXVI-XXXVII), trad. y nts. Gerónimo Huerta, México, Universidad Nacional Autónoma de México, 1976, vol. II a.

Puiny, Natural history (libro I), vol. I, trad. H. Rackham, Cambridge, Harvard University Press (The Loeb Classical Library, 330), 1949 (2 reimp.).

-, Natural history (libro VII), vol. II, trad. H. Rackham, Cambridge, Harvard University Press (The Loeb Classical Library, 352), 1969 ( $3^{\circ}$ reimp.).

—, Natural history (libro VIII), vol. III, trad. H. Rackham, Cambridge, Harvard University Press (The Loeb Classical Library, 353), 1967 (3 reimp.).

-, Natural history (libro XXXIV), vol. IX, trad. H. Rackham, Cambridge, Harvard University Press (The Loeb Classical Library, 394), 1968 ( ${ }^{\circ}$ reimp.).

-, Natural history (libro XXXVI), vol. X, trad. D. E. Eichholz, Cambridge, Harvard University Press (The Loeb Classical Library, 419), 1962.

Plutarch, Lives: Agesilaus and Pompey, Demosthenes and Cicero, Alexander and Cesar, Sertorius and Eumenes, Phocion and Cato the young, trad. B. Perrin, Cambridge, Harvard University Press (The Loeb Classical Library, 87, 99, 100), 1967 (4 reimp.), vols. V, VII y VIII.

Plutarco, Vidas paralelas: Pericles-Fabio Máximo, trad. A. Pérez Jiménez, Madrid, Gredos, 1996, vol. II. 
Porfirio, Vida de Pitágoras, trad. M. Periago Lorente, Madrid, Gredos, 1987.

Scholia Graeca in Homeri Iliadem, Hartmut Erbse (ed.), Berlin, Walter von Grunter et al., 1975, vol. IV.

Scholia Graeca in Homeri Iliadem, Hartmut Erbse (ed.), Berlin, Walter von Grunter et al., 1977, vol. V.

Scholia in Theocritum vetera, C. Wendel (ed.), Stuttgart, Bibliotheca Scriptorum Graecorum et Romanorum Teubneriana, 1966.

Scholia in Vespas, Pacem, Aves et Lysistratam, W. J. W. Koster (ed.), Groningen, Bouma's Boekhuis B. V., 1978.

Strabo, The geography of Strabo, trad. H. L. Jones, Cambridge, Harvard University Press (The Loeb Classical Library, 49), 1969 (4 reimp.).

Suidae lexicon, lexicographi Graeci, Ada Adler (ed.), Stuttgart, B. G. Teubner, 1967, vol. II.

Suidae lexicon, lexicographi Graeci, Ada Adler (ed.), Stuttgart, B. G. Teubner, 1971, vol. IV.

\section{Bibliografía básica}

Finley, M. I., Historia antigua, Barcelona, Crítica, 1986.

HАвіснт, C., Gottmenschentum und griechische Städte, Munich, Zetemata, 1956.

Lesky, A., Historia de la literatura griega, trad. J. Ma. Díaz R. \& B. Romero, Madrid, Gredos, 1968.

Shipley, G., El mundo griego después de Alejandro 323-30 A. C., trad. Magdalena Chocano, Barcelona, Crítica, 2001.

TAPIA ZÚÑIga, P. C., "La areté en la época helenística”, Noua tellus, 9-10, 1991-1992, pp. 289-301.

Wilamowitz-Moellendorf, U., Hellenistische Dichtung in der Zeit des Kallimachos I, Berlin, Weimannsche Buchhandlung, 1924.

WILL, E., et al., El mundo griego y el oriente II: el siglo IV y la época helenística, trad. Francisco J. Fernández N. \& A. Noguera B., Madrid, Akal, 1998.

\section{Bibliografía especializada}

Barron, J., "The tyranny of Duris of Samos", Classical Review, XII, 1962, pp. 189-192.

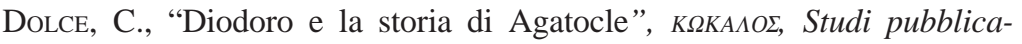
ti dall'Istituto di Storia antica dell'Universitá di Palermo, VI, 1960, pp. 124-166. 
KeBric, R. B., In the shadow of Macedon. An historiographical study of Duris of Samos, Binghamton, Diss. State Univ. of New York, 1972.

—, "A note on Duris in Athens", Classical Philology, LXIX, 1974, pp. 286-287.

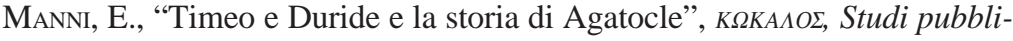
cati dall'Istituto di Storia antica dell'Universitá di Palermo, VI, 1960, pp. 167-173.

Mastrocinque, A., "Demetrius tragodoumenos Athenaeum", Studi periodici di letteratura e Storia dell' Antichità, LVII, Pavia, Università, 1979, pp. 260-276.

Pédech, P., Trois historiens méconnus: Théopompe, Duris, Phylarque, Paris, "Les Belles Lettres" (Coll. d’Études Anc., 119), 1989. 